\author{
Barbara KACZYŃSKA \\ https://orcid.org/0000-0003-0421-9205 \\ Wydział Lingwistyki Stosowanej Uniwersytetu Warszawskiego
}

\title{
Wokabularz trydencki jako przykład leksykografii średniowiecznej
}

Zarys treści: Tematem artykułu jest wokabularz trydencki jako przykład leksykografii średniowiecznej na ziemiach polskich. Przedstawiona została analiza słownictwa zawartego w wokabularzu, jego makrostruktura, źródła i geneza. Omówiono związki słownika z formularzem trydenckim, w którym został zapisany, a także możliwe powiązania z postacią księcia i biskupa Aleksandra mazowieckiego oraz członkami jego świty. Podjęto próbę określenia prawdopodobnego celu powstania i funkcji wokabularza.

\begin{abstract}
The article's subject is the vocabulary of Trento as an example of medieval lexicography in Poland. It presents the analysis of the vocabulary's linguistic material, its macrostructure, sources and origin, discussing the dictionary's relation to the formulary of Trento, in which it was written, as well as possible connections to Prince and Bishop Alexander of Mazovia and members of his suite. The author attempts to determine the vocabulary's probable aim and function.
\end{abstract}

Słowa kluczowe: wokabularz trydencki, leksykografia średniowieczna, formularz trydencki, Aleksander mazowiecki, Graecismus Eberharda z Béthune

Keywords: vocabulary of Trento, medieval lexicography, formulary of Trento, Alexander of Mazovia, Graecismus by Eberhard of Béthune

\section{Leksykografia w średniowieczu}

\subsection{Trudności terminologiczne}

Współczesna definicja słownika jako „zbioru wyrazów ułożonych i opracowanych według pewnej zasady, zwykle alfabetycznie, najczęściej objaśnianych pod względem znaczeniowym i ilustrowanych przykładami użycia"1 odzwierciedla dzisiejszy kształt tego gatunku tekstu i nie przystaje do dzieł średniowiecznych. W literaturze przedmiotu skrzyżowanie terminologii współczesnej i średniowiecznej rodzi nierzadko niekonsekwencje, tym bardziej że ta ostatnia nie była bynajmniej ściśle ustalona. Na jej obfitość i brak precyzji zwróciła uwagę Olga Weijers². Z wielu określeń, jakich używano w średniowieczu

\footnotetext{
${ }^{1}$ Słownik języka polskiego PWN, 2004 [wersja elektroniczna]. Definicję pełniejszą, bardziej szczegółową, ale i tym samym jeszcze bardziej związaną ze słownikami współczesnymi podaje np. Słownik terminów literackich, red. M. Głowiński, T. Kostkiewiczowa, A. Okopień-Sławińska, J. Sławiński, Wrocław 2008, s. 513.

2 O. Weijers, Lexicography in the Middle Ages, „Viator - Medieval and Renaissance Studies”, 20, 1989, s. 139-153; taż, Les dictionnaires et autres répertoires, w: Méthodes et instruments du travail intellectuel au moyen âge. Études sur le vocabulaire intellectuel du moyen âge, red. O. Weijers, Turnhout 1990, s. 197-208; taż, Dictionnaires et répertoires au moyen âge. Une étude du vocabulaire, Turnhout 1991.
} 
do tytułowania dzieł leksykograficznych, bliższego omówienia wymagają dwa występujące najczęściej, tj. glosariusz (glossarium) i wokabularz (vocabularium, vocabularius). Dla Kateřiny Volekovej kwestią decydującą jest pochodzenie materiału zawartego w słowniku: w przypadku glosariuszy były to glosy, wokabularze stanowiły zaś efekt własnej działalności zbierackiej i przekładowej autora (przez co należy chyba rozumieć również działalność kompilatorską) ${ }^{3}$. Natomiast O. Weijers, choć odnotowuje pierwotny związek glosariuszy z praktyką glosowania, za ich cechę konstytutywną uznaje lakoniczność (wyraz hasłowy był objaśniany najczęściej przy pomocy jednego lub dwóch odpowiedników, bez informacji gramatycznych lub przykładów użycia). Glossarium to również jeden z najstarszych terminów na określenie dzieła leksykograficznego. Popularne w późnym średniowieczu vocabularium pojawiło się nie wcześniej niż w XIV w. i mogło odnosić się do bardziej złożonych słowników, które nie były już traktowane jako zbiory glos, lecz zbiory słów (vocabula), wraz z dodatkowymi danymi leksykograficznymi, takimi jak informacja gramatyczna czy cytaty egzemplifikujące użycie danego wyrazu. Dość często wokabularzami tytułowano słowniki terminologii prawniczej'

Sytuację komplikuje fakt, że w praktyce często nie rozróżniano wokabularzy od glosariuszy ${ }^{5}$. Za przykład może posłużyć XI-wieczny słownik Papiasa, wymieniany często jako pierwszy wielki słownik średniowieczny. Sam Papias (określany później przydomkiem Vocabulista) zatytułował go Elementarium doctrinae rudimentum, a w przedmowie stwierdził, że zawierając $\mathrm{w}$ nim nie tylko proste objaśnienia, lecz również definicje, etymologie i ilustrujące hasło cytaty, stworzył coś więcej niż glosariusz 6 . Mimo to w rękopisach jego dzieło bywa tytułowane właśnie jako glossarium, jak również alphabetum, breviarium i vocabularium?

W obliczu tych trudności w niniejszym artykule zdecydowano się na użycie jak najprostszej terminologii, która w miarę możliwości nie byłaby sprzeczna ze średniowiecznym nazewnictwem ani nie zrywałaby $\mathrm{z}$ dotychczasową praktyką obecna $\mathrm{w}$ literaturze przedmiotu, a jednocześnie unikałaby niejednoznaczności. Wzorem wcześniejszej polskiej literatury ${ }^{8}$ zastosowano termin „słownik” w najszerszym, intuicyjnym znaczeniu, obejmującym każdy zbiór wyrazów opatrzonych objaśnieniami w tym samym lub innym języku, mający określoną mikro- i makrostrukturę 9 . Bez znaczenia jest również długość i rodzaj informacji zawartych w tych objaśnieniach, pod warunkiem, że przynajmniej w większości dotyczą one znaczenia wyrazów hasłowych, tj. rzeczywistości językowej. Mniej uwagi poświęcono dziełom leksykograficznym koncentrującym się na rzeczywistości empirycznej (w dzisiejszym rozumieniu: encyklopedycznym ${ }^{10}$ ). Do tych ostatnich zaliczyć można Etymologiae Izydora z Sewilli (ok. 560-636) czy Speculum maius Wincentego z Beauvais (ok. 1190-1264) ${ }^{11}$. Oba te dzieła są dziś określane

${ }^{3}$ K. Voleková, Česká lexikografie 15. století, Praha 2015, s. 11.

${ }^{4}$ O. Weijers, Dictionnaires et répertoires au moyen âge, s. 45 n.

5 Taż, Lexicography in the Middle Ages, s. 151.

${ }^{6}$ L.W. Daly, B.A. Daly, Some Techniques in Mediaeval Latin Lexicography, „Speculum”, 39, 1964, nr 2, s. 230.

7 O. Weijers, Lexicography in the Middle Ages, s. 141; J.-C. Boulanger, Les inventeurs de dictionnaires. De l'eduba des scribes mésopotamiens au scriptorium des moines médiévaux, Ottawa 2003, s. 273.

${ }^{8} \mathrm{Na}$ przykład T. Michałowska, Literatura polskiego średniowiecza, Warszawa 2011. W artykule nie skorzystano z propozycji terminologicznej M. Leńczuka (tenże, Zapisy polskie w stownikach i glosariuszach XV w. - terminy, źródta, perspektywy badawcze, „Polonica”, 35, 2015, s. 103-114), postulującej podział nadrzędnej kategorii słowników-wokabularzy na bardziej wyczerpujące tezaurusy i lakoniczne glosariusze, ze względu na jej arbitralność i rozbieżność z kategoriami pojęciowymi stosowanymi w średniowieczu (por. m.in. rzadkie występowanie określenia thesaurus w nazewnictwie średniowiecznych słowników; J.-C. Boulanger, Les inventeurs de dictionnaires, s. 459).

${ }^{9}$ Mikrostruktura to sposób organizacji danych leksykograficznych w obrębie artykułu hasłowego, makrostruktura oznacza natomiast sposób uporządkowania artykułów hasłowych w obrębie słownika (np. alfabetyczny lub rzeczowy). W przypadku niektórych słowników średniowiecznych, takich jak Vocabula rethoricalia, nie da się dostrzec wyraźnego zamysłu w kolejności haseł, makrostruktura jest zatem trudna do nazwania i określenia; zob. T. Michałowska, Literatura polskiego średniowiecza, s. 860

10 Pojęcia „słownik” i „encyklopedia” są jednak historycznie zmienne, a przy tym nie oznaczają dwóch całkowicie odrębnych nurtów, lecz reprezentują dwa krańce spektrum dzieł leksykograficznych; T. McArthur, Thematic Lexicography, w: The History of Lexicography, red. R.R.K. Hartmann, Amsterdam-Philadelphia 1986, s. 157 n.

11 J.-C. Boulanger, Les inventeurs de dictionnaires, s. 304-305. 
jako ,Średniowieczne encyklopedie”, warto jednak pamiętać, że nie zabrakło w nich części poświęconej słownictwu i gramatyce, a więc rzeczywistości językowej, aczkolwiek pełni ona rolę służebną wobec poznania rzeczywistości empirycznej. Tak więc np. Etymologiae oparte są na założeniu, że zrozumienie słowa - do którego dociera się chociażby przez zrozumienie jego etymologii - gwarantuje poznanie rzeczy ${ }^{12}$.

Z uwagi na wieloznaczność i niepewną definicję termin „wokabularz” używany jest w niniejszym artykule wyłącznie w sytuacji przywoływania nazw konkretnych słowników, czy to średniowiecznych (np. Vocabularius brevilogus, Vocabularius Ex quo), czy współczesnych, ale utrwalonych w literaturze przedmiotu (taka sytuacja zachodzi właśnie w przypadku wokabularza trydenckiego).

Problematyczny jest termin ,glosariusz”, pod którym w literaturze rozumie się albo słownik powstały bezpośrednio na bazie zbioru glos (istotne jest wówczas pochodzenie zawartego w nim materiału), albo krótki słownik zawierający minimalne objaśnienia wyrazów hasłowych ${ }^{13}$ (tu nacisk położony jest na formę, a glosariusz traktowany jest jako najprostsza forma słownika). Zważywszy na szerokie stosowanie tego określenia w nazewnictwie średniowiecznym i jego utrwalone znaczenie we współczesnej terminologii leksykograficznej, zachowanie tej dwuznaczności wydaje się nieuniknione. Pewnym uściśleniem może być rozróżnianie - tam, gdzie jest to niezbędne - glosariuszy „formalnych”, czyli słowników mających formę glosariusza, oraz glosariuszy „właściwych” ( glossae collectae).

Powyższa terminologia jest w pewnej mierze arbitralna i nie pozwala na wyczerpującą kategoryzację średniowiecznych dzieł leksykograficznych, jednak jej uszczegółowienie wymaga dalszych badań nad całym korpusem słowników średniowiecznych. Wybrane pojęcia należące do uzusu średniowiecznego (m.in. nominalia czy mamotrekt) zostaną omówione w dalszej części tekstu.

\subsection{Ksztaltowanie się leksykografii średniowiecznej}

W przeciwieństwie do „encyklopedycznej” tendencji leksykograficznej, dostarczającej informacji o świecie empirycznym, dla nurtu filologicznego priorytetem jest zapewnienie użytkownikowi słownika pomocy w uczeniu się języka, rozumieniu tekstów i tworzeniu nowych. W średniowieczu nurt ten powiązany był z gramatyką i retoryką, a obok słowników sensu stricto należały do niego zbiory modelowych tekstów na określony temat (colloquia i dialogi, z których wyewoluowały „rozmówki”), a także traktaty dydaktyczne ${ }^{14}$, takie jak Graecismus Eberharda z Béthune (zm. 1212), przedstawiający w formie wierszowanej zagadnienia z zakresu gramatyki i retoryki ${ }^{15}$. Wpływ leksykografii starożytnej - niezbyt zresztą bogatej $^{16}$ - na średniowieczną wydaje się znikomy, ograniczony do skrótu dokonanego w VIII w. przez Pawła Diakona z II-wiecznego De significatu verborum Festusa Sekstusa Pompejusza ${ }^{17}$. Ze starożytności przetrwały nie tyle dzieła leksykograficzne, ile pewne praktyki, przede wszystkim glosowanie. Choć w pierwotnym greckim znaczeniu glosa oznaczała nieznany wyraz wymagający objaśnienia, współcześnie stosuje się ten termin niemal wyłącznie w jego łacińskim sensie, a mianowicie jako objaśnienie nieznanego wyrazu wpisane na marginesie tekstu (glosy marginalne) lub między jego linijkami (glosy interlinearne). Istnieją glosy interpretacyjne, polegające na wyjaśnieniu danego słowa czy ustępu, oraz glosy przekładowe, zawierające thumaczenie danego słowa na inny język ${ }^{18}$. W starożytności glosowano

12 Tamże, s. 16, 264, 387.

13 Tak rozumiany jest glosariusz (ang. glossary, fr. glossaire) współcześnie i wiązany jest przede wszystkim z glottodydaktyką; zob. I. Burkhanov, Lexicography. A Dictionary of Basic Terminology, Rzeszów 2010, s. 92.

${ }^{14}$ C. Buridant, Lexicographie et glossographie médiévales. Esquisse de bilan et perspectives de recherche, „Lexique 4. La lexicographie au Moyen Âge", 1986, s. 17 n., 22.

15 J.-C. Boulanger, Les inventeurs de dictionnaires, s. 296.

${ }^{16}$ O. Weijers, Dictionnaires et répertoires au moyen âge, s. 41

17 Tamże; J.-C. Boulanger, Les inventeurs de dictionnaires, s. 203; B. Otwinowska, Stowniki, w: Stownik literatury staropolskiej, red. T. Michałowska, Wrocław-Warszawa-Kraków 1990, s. 779.

${ }^{18}$ K. Voleková, Česká lexikografie, s. 13. 
dawne teksty, których język przestał być zrozumiały, np. dzieła Homera ${ }^{19}$. Glosy spotyka się również w tekstach akkadyjskich i sumeryjskich, nie występują natomiast w hebrajskiej Bibliii ${ }^{20}$.

Łacińskie thumaczenie Biblii glosowano za to obficie w średniowieczu. Praktyką tą obejmowano także inne teksty, zarówno klasyczne (przykładem może być glosariusz Abstrusa z początku VII w., ułożony na podstawie komentarza do Wergiliusza) ${ }^{21}$, jak i średniowieczne traktaty religijne, prawnicze lub gramatyczno-dydaktyczne ${ }^{22}$. Przykładem glos tłumaczeniowych są XV-wieczne polskie glosy do kazań, które - choć spisane po łacinie - były wygłaszane w języku narodowym, w czym glosy mogły okazać się pomocne. Pewną zagadkę stanowi fakt, że nie zawsze glosowano wyrazy trudne i rzadkie; wręcz przeciwnie, wiele glos pojawia się przy słowach wręcz pospolitych, jak caritas lub ecclesia ${ }^{23}$.

W zachodniej Europie od początku VII w. zaczęto zbierać i notować trudne wyrazy wraz z odpowiadającymi im glosami na osobnych kartach, nierzadko w porządku alfabetycznym (czy raczej prealfabetycznym, ponieważ ograniczał się on do grupowania razem wszystkich słów zaczynających się na tę samą literę) $)^{24}$. Powstałe w ten sposób glossae collectae czy glossaria zawierały objaśnienia zdekontekstualizowane, choć w dalszym ciągu ograniczone do tego znaczenia, jakie dane słowo miało w konkretnym tekście, od którego zostało niejako oderwane ${ }^{25}$. Wykształcona w ten sposób tradycja glosograficzna stała się fundamentem całej późniejszej leksykografii ${ }^{26}$ : przepisywane przez kolejnych kopistów, glosariusze były modyfikowane, skracane i amplifikowane na podstawie innych źródeł, prowadząc do powstania nowych glosariuszy, a później również bardziej złożonych słowników.

Największym średniowiecznym glosariuszem był powstały we Francji pod koniec VIII w. Glossarium Ansileubi, znany też jako Liber glossarum. Składał się on z ponad 50 tys. glos, a czerpał z glosariuszy wcześniejszych oraz dzieł Izydora z Sewilli i Ojców Kościoła ${ }^{27}$. Liber glossarum był ważnym źródłem dla kolejnych dzieł leksykograficznych, takich jak IX-wieczne Glossae a Salomone collectae, znane też jako Vocabularius Salomonis i Mater verborum ${ }^{28}$. Mimo nazw sugerujących słownik językowy, w literaturze bywa określany jako encyklopedia ${ }^{29}$, co stanowi dowód na płynność granic między typami średniowiecznych dzieł leksykograficznych. Już w VIII w. zaczęły pojawiać się glosariusze wielojęzyczne (łacińsko-wernakularne) i one też przetrwały najdłużej, w przeciwieństwie do glosariuszy całkowicie łacińskich, które w późniejszych wiekach ustąpiły miejsca słownikom zawierającym więcej danych leksykograficznych, takich jak informacja gramatyczna i przykłady użycia ${ }^{30}$.

19 J.-C. Boulanger, Les inventeurs de dictionnaires, s. 208.

${ }^{20}$ E. Tov, Glosses, Interpolations, and Other Types of Scribal Additions in the Text of the Hebrew Bible, w: tenże, The Greek and Hebrew Bible, Leiden-Boston 1999, s. 54, 73 n.

21 J.-C. Boulanger, Les inventeurs de dictionnaires, s. 268.

22 C. Buridant, Lexicographie et glossographie médiévales, s. 12.

${ }^{23}$ E. Belcarzowa, Glosy polskie w tacińskich kazaniach średniowiecznych, cz. 3, Kraków 1997, s. 67; zob. też M. Leńczuk, Polskie glosy w XV-wiecznych łacińskich rękopisach jako problem historycznojęzykowy, w: Jak badać teksty staropolskie, red. T. Mika, D. Rojszczak-Robińska, O. Stramczewska, Poznań 2015, s. 80: „,analiza średniowiecznych komentarzy dowodzi, iż to nie znaczenie inusitata czy peregrina staje się głównym przedmiotem zainteresowania pisarzy, ale znaczenia wyrazów dobrze znanych i łatwo użytkownikowi dostępnych". Więcej o polskich glosach zob. m.in. tenże, Problemy terminologiczne w opisywaniu glos polskich na przykładzie XV-wiecznych tlumaczeń kanonu mszy św., „Kwartalnik Językoznawczy”, 2010, nr 2, s. 19-37. Objaśnianie pospolitych słów występuje również w mamotrektach; S. Urbańczyk, Słowniki, ich rodzaje i użyteczność, Wrocław 1964, s. 11.

${ }^{24}$ O. Weijers, Dictionnaires et répertoires au moyen âge, s. 41.

25 C. Buridant, Lexicographie et glossographie médiévales, s. 12; W.M. Lindsay, Note on the Use of Glossaries for the Dictionary of Medieval Latin, „ALMA” („Bulletin Ducange”), 1, 1924, s. 16 n.

${ }^{26}$ C. Buridant, Lexicographie et glossographie médiévales, s. 26.

${ }^{27}$ O. Weijers, Lexicography in the Middle Ages, s. 140; taż, Dictionnaires et répertoires au moyen âge, s. 41.

${ }^{28}$ Pod tą ostatnią nazwą znany jest przede wszystkim w Czechach, gdzie ważnym zabytkiem jest jego XIII-wieczna kopia w rękopisie Biblioteki Muzeum Narodowego w Pradze o sygn. X A 11, zawierająca liczne niemieckie i czeskie glosy z różnych okresów; K. Voleková, Česká lexikografie, s. 38-40.

29 P. Rychterová, The Manuscripts of Grünberg and Königinhof. Romantic Lies about the Glorious Past of the Czech Nation, w: Manufacturing a Past for the Present. Forgery and Authenticity in Medievalist Texts and Objects in Nineteenth-Century Europe, red. J.M. Bak, P.J. Geary, G. Klaniczay, Leiden-Boston 2014, s. 23.

${ }^{30} \mathrm{O}$. Weijers, Dictionnaires et répertoires au moyen âge, s. 42. 
Obok tradycji glosograficznej istniał nurt leksykograficzny związany ściślej z dydaktyką języka, nie zaś z lekturą określonych tekstów, choć jego bezpośrednim efektem również były słowniki mające formę glosariusza, określane jednak jako vocabularia rerum, hermeneumata albo nomina czy nomina$\mathrm{lia}^{31}$. Ważnym przedstawicielem tego gatunku są Nomina multarum rerum anglice, ułożone ok. $1000 \mathrm{r}$. przez Aelfrica z Canterbury, biskupa Eynsham, zwanego Gramatykiem, który był również autorem innych pomocy do nauczania łaciny klasztornych nowicjuszy ${ }^{32}$. Późniejszymi dziełami tego typu były De nominibus utensilium Aleksandra Neckama (druga połowa XII w.) lub Dictionarius Jana z Garlandii (początek XIII w.). Zjawiskiem znacznie rzadszym były nominalia służące nie do nauki łaciny, lecz języka wernakularnego, np. francuskiego, jak powstałe w XIII-wiecznej Anglii Nominale Waltera z Bibbesworth $^{33}$. Nominalia mogły również ograniczać się do konkretnej dziedziny, np. terminologii prawniczej lub teologicznej, nazw stosunków pokrewieństwa albo nazw roślin leczniczych ${ }^{34}$. Bardziej gramatyczno-retoryczny charakter miały zbiory synonimów (synonyma) oraz homonimów i paronimów (equivoca) ${ }^{35}$.

Jako najważniejsze średniowieczne słowniki, które mogły mieć ambicję opisania całokształtu łacińskiego słownictwa, wymienia się zazwyczaj dzieła Papiasa, Osberna z Gloucester, Huguciona z Pizy i Jana de Balbis z Genui ${ }^{36}$. Czerpiąc z wcześniejszej tradycji glosograficznej, gramatycznej i hermeneutycznej, stanowią one ciąg rozwojowy, ponieważ Hugucio czerpał i ze słownika Papiasa, i Osberna, Jan de Balbis zaś wykorzystał dzieła wszystkich trzech poprzedników.

Hasła w XI-wiecznym słowniku Elementarium doctrinae rudimentum Papiasa zwanego Vocabulistą ${ }^{37}$ były bardzo zróżnicowane - niektóre $\mathrm{z}$ nich zachowały glosariuszową zwięzłość, inne zaś były bardzo obszerne i miały charakter encyklopedyczny ${ }^{38}$. O wartości słownika świadczyły informacje gramatyczne na temat rodzaju rzeczowników czy deklinacji czasowników ${ }^{39}$, z cytatami egzemplifikującymi użycie poszczególnych wyrazów, istotnym osiągnięciem był również porządek alfabetyczny doprowadzony aż do trzeciej litery oraz zastosowanie - obok metody expositio, czyli objaśnienia definicyjnego ${ }^{40}$ - metody derivatio.

Warto w tym miejscu poświęcić kilka słów sposobom organizacji treści w słownikach średniowiecznych. Współcześnie w leksykografii wyróżnia się dwa typy makrostruktury: alfabetyczny i ideograficzny, zwany też rzeczowym, tematycznym lub pojęciowym. Ten pierwszy wiązany jest z leksykografią językową, ten drugi zaś - z encyklopedyczną ${ }^{41}$. W rzeczywistości związki te nie są tak oczywiste - można sobie wyobrazić słownik językowy w układzie rzeczowym, a tym bardziej dzieło encyklopedyczne w układzie alfabetycznym ${ }^{42}$. W średniowiecznej praktyce makrostruktura słowników była przeważnie mieszana, czego przykładem są powstałe w połowie XII w. Panormia lub Derivationes Osberna z Gloucester, który niezależnie od Papiasa zastosował derivatio równolegle do alfabetycznej glosografii ${ }^{43}$.

${ }^{31}$ Taż, Lexicography in the Middle Ages, s. 146; J.-C. Boulanger, Les inventeurs de dictionnaires, s. 448 n.; C. Buridant, Lexicographie et glossographie médiévales, s. 14.

32 J.-C. Boulanger, Les inventeurs de dictionnaires, s. 240.

${ }^{33}$ C. Buridant, Lexicographie et glossographie médiévales, s. 14.

${ }^{34}$ M. Plezia, Dzieje leksykografii łacińskiej w Polsce, w: Stownik łacińsko-polski, Warszawa 1959, s. VII.

${ }^{35}$ O. Weijers, Dictionnaires et répertoires au moyen âge, s. 53.

${ }^{36}$ M. Plezia, Dzieje leksykografii łacińskiej w Polsce, s. V.

37 Ponieważ o życiu Papiasa wiadomo bardzo niewiele, niektórzy badacze wysuwali tezę, że słowo „Papias”, po grecku oznaczające m.in. karmiciela, pierwotnie było nazwą słownika, którą dopiero później zaczęto rozumieć jako imię twórcy; J.-C. Boulanger, Les inventeurs de dictionnaires, s. 273. M. Leńczuk (tenże, Zapisy polskie, s. 104) twierdzi natomiast, że „Vocabulista” było nazwą słownika Papiasa (i to częstszą niż Elementarium doctrinae rudimentum) oraz późniejszego słownika Bertolda z Eisenach, zachowanego w rękopisie BJ nr 228. Słuszniejsza wydaje się teza, że nawet jeśli słowniki bywały w rękopisach tytułowane jako „Vocabulista”, działo się tak w wyniku metonimicznego użycia przydomka leksykografa jako nazwy jego dzieła.

${ }^{38}$ O. Weijers, Lexicography in the Middle Ages, s. 141; zob. B. Otwinowska, Stowniki, s. 779, gdzie słownik Papiasa zostaje zaliczony do „encyklopedycznych”, w opozycji do słowników „etymologicznych”, takich jak Derivationes Huguciona (zob. niżej).

${ }^{39}$ Choć w tym względzie słownik Papiasa nie zawsze jest konsekwentny; L.W. Daly, B.A. Daly, Some Techniques, s. 235.

40 A. Rossebastiano Bart, Alle origini della lessicografia italiana, „Lexique 4. La lexicographie au Moyen Âge”, 1986, s. 113.

${ }^{41}$ I. Burkhanov, Lexicography, s. 118.

42 T. McArthur, Thematic Lexicography, s. 158.

${ }^{43}$ O. Weijers, Lexicography in the Middle Ages, s. 142. 
Ta związana z etymologią metoda opiera się na założeniu, że istnieją rodziny wyrazów wywodzące się od wspólnego przodka - słowa pierwotnego czy rdzennego ${ }^{44}$. Zanim przeszła do leksykografii, należała do dziedziny gramatyki (np. u Pryscjana) i wchodziła w zakres ćwiczeń szkolnych, ułatwiając zrozumienie i zapamiętanie sensu słów ${ }^{45}$. Do leksykografii po raz pierwszy wprowadził ją Papias, którego słownik był w zasadzie alfabetyczny, jednak podawał również derywaty pochodzące od wyrazu hasłowego, zazwyczaj czasownika ${ }^{46}$. We współczesnych słownikach odpowiednikiem derivatio jest układ gniazdowy, który w literaturze wraz z układem rzeczowym zaliczany jest do ogólnej kategorii układów niealfabetycznych ${ }^{47}$, co wynika z dominacji porządku alfabetycznego w naszych czasach. W przypadku leksykografii średniowiecznej odpowiedniejszy byłby podział na porządek onomazjologiczny, związany z semantyką wyrazów, i semazjologiczny, związany z ich formą - i do tej właśnie kategorii należałby zarówno układ alfabetyczny, jak i derivatio.

Tę ostatnią do ostatecznych granic ${ }^{48}$ doprowadził Hugucio z Pizy ${ }^{49}$, kompilując w drugiej połowie XII w. swoje Derivationes, zwane magnae lub maiores, znane również jako Liber derivationum, wpisujące całe słownictwo łacińskie w ramy struktury derywacyjnej. Hasła ułożone są w porządku alfabetycznym ograniczonym do pierwszej litery, a w obrębie każdego z nich umieszczono wyrazy, które Hugucio uznał za spokrewnione $\mathrm{z}$ wyrazem hasłowym, kierując się kryteriami zarazem naiwnymi i erudycyjnymi ${ }^{50}$. Jako że wiele wyrazów wymienionych jest tylko wewnątrz haseł poświęconych wyrazom podstawowym, nieraz zaczynających się na inną literę niż derywat, już w XIII w. powstały repertoria, czyli indeksy do Derivationes ${ }^{51}$, umożliwiające wyszukanie konkretnego wyrazu w słowniku Huguciona.

Również w XIII w. w pełni wykształcił się znany nam porządek alfabetyczny. Przedtem, mimo że przejęto rzymską praktykę alfabetycznych list terminów medycznych, klejnotów, wyrazów rzadkich itp., alfabetyczny porządek w glosariuszach ograniczał się przeważnie do pierwszej lub pierwszych dwóch liter wyrazu ${ }^{52}$ (aż do trzeciej litery doprowadził go Papias). Trudności z alfabetyzacją wynikały nie tylko z pracochłonności, lecz przede wszystkim z niestabilnej grafii ${ }^{53}$ oraz rozbieżności między pisownią przekazaną przez tradycję a ewolucją wymowy. Rozwiązaniem było albo zastosowanie pisowni wynikającej z wymowy (np. zrównanie aeloe z $e$, jak to uczynił Wilhelm Brito w Expositiones vocabulorum Biblie ${ }^{54}$ ), albo arbitralne ustalenie jednej pisowni dla każdego wyrazu (jak w Catholiconie dominikanina Jana de Balbis z Genui $)^{55}$.

44 Taż, Les dictionnaires et autres répertoires, s. 200.

45 Taż, Lexicography in the Middle Ages, s. 147.

46 Tamże, s. 143.

47 P. Żmigrodzki, Wprowadzenie do leksykografii polskiej, Katowice 2009, s. 52 n.

48 O. Weijers, Lexicography in the Middle Ages, s. 143.

${ }^{49}$ W literaturze polskiej można spotkać również formy imienia Ugucio (J. Łoś, Początki piśmiennictwa polskiego, Lwów 1922, s. 114), Uguzio (Mamotrekty staropolskie, cz. 1, oprac. W. Żurowska-Górecka, V. Kyas, Wrocław 1977, s. V), Hugwicjo, Ugucjo, Hugucjo (M. Leńczuk, Zapisy polskie, s. 104) oraz Hugo (T. Michałowska, Literatura polskiego średniowiecza, s. 771). Podobnie jak Aelfric, Hugucio był także autorem innych dzieł, które można by określić jako językoznawcze i dydaktyczne. Jednym z nich jest gramatyka zatytułowana Rosarium lub Rosarius, którą M. Leńczuk (tenże, Zapisy polskie, s. 104) chyba niesłusznie utożsamia z Derivationes.

${ }^{50}$ O. Weijers, Lexicography in the Middle Ages, s. 149.

${ }^{51}$ L.W. Daly, B.A. Daly, Some Techniques, s. 235.

52 O. Weijers, Lexicography in the Middle Ages, s. 150.

53 Taż, Dictionnaires et répertoires au moyen âge, s. 16.

${ }^{54}$ Nazywany też Vocabulorium Biblie czy Summa Britonis, słownik ten powstał w drugiej połowie XIII w. (niedługo przed Catholiconem) i zachował się w 130 rękopisach, co świadczy o jego popularności; P. Courcelle, Summa Britonis sive Guillelmi Britonis expositiones vocabulorum Biblie (rec.), „Bibliothèque de l'école des chartes”, 134, 1976, s. 143. Jego autor - franciszkanin Wilhelm Brito - dokonał wyboru z dzieł Papiasa i Huguciona, i ograniczył się do 2500 wyrazów, w większości występujących w Piśmie Świętym i w liturgii. Hasła opatrzył cytatami z Biblii, ale też z pisarzy klasycznych lub średniowiecznych; O. Weijers, Lexicography in the Middle Ages, s. 145; J.-C. Boulanger, Les inventeurs de dictionnaires, s. 288-289. M. Plezia (tenże, Dzieje leksykografi łacińskiej w Polsce, s. VII) podaje, że słownik Wilhelma Brito był wierszowany, wydaje się jednak, że w rzeczywistości wierszowana była jedynie przedmowa; zob. J.-C. Boulanger, Les inventeurs de dictionnaires, s. 288.

${ }^{55} \mathrm{~K}$. Miethaner-Vent, L'alphabétisation dans la lexicographie médiévale; ordre alphabétique, ses différents emplois, ses formes et son développement, „Lexique 4. La lexicographie au Moyen Âge”, 1986, s. 111. 
Jako szczytowe osiągnięcie leksykografii średniowiecznej wymienia się często ten ostatni słownik, czy raczej jego piątą część (cztery wcześniejsze były poświęcone różnym działom gramatyki) ${ }^{56}$. Powstały pod koniec XIII w. Catholicon zawierał blisko 670 tys. słów z łaciny klasycznej, biblijnej i średniowiecznej, i stosował porządek alfabetyczny do ostatniej litery wyrazu, ze znacznie zredukowaną rolą derivatio $^{57}$. Ogromnie popularny, zachował się w ponad 200 rękopisach $^{58}$. Był też pierwszym słownikiem, jaki został wydrukowany (już w 1460 r.) i do końca XV w. miał 24 wydania ${ }^{59}$.

Pojawienie się pełnego porządku alfabetycznego nie oznaczało jego natychmiastowego triumfu. W słownikach XIV- i XV-wiecznych bywał on nadal ograniczony do kilku pierwszych liter, przyjmował formy odmienne niż znane nam współcześnie, a nieraz podporządkowywano go innym sposobom organizacji, np. według tematu lub derivatio ${ }^{60}$. W literaturze rozwój i upowszechnienie porządku alfabetycznego przedstawia się czasem - choćby w domyśle - jako postęp. Wynika to ze współczesnej koncepcji słownika, którego główną funkcją jest rozwiązanie konkretnego problemu ze zrozumieniem dowolnego tekstu ${ }^{61}$. Początków takiego rozumienia słowników można upatrywać w przekształceniu metod pracy intelektualnej, do którego doszło w XII i XIII w.: ówcześni ludzie „chcieli już nie tylko czytać teksty, lecz również móc wyszukiwać fragmenty, tematy i myśli, by następnie wykorzystać je we własnych pracach, w szczególności w kazaniach" ${ }^{2}$. To prowadziło do powstania konkordancji, zbiorów exemplów i distinctiones (czyli słowników objaśniających różne znaczenia wyrazów), a przede wszystkim do rozwoju porządku alfabetycznego, który umożliwiał łatwe wyszukiwanie, przydatne np. przy pracy thumaczeniowej ${ }^{63}$. Jest to jednak jedyna jego zaleta, stąd też nie był w średniowieczu wysoko ceniony $^{64}$. Jeszcze w 1647 r. francuski gramatyk Claude Favre de Vaugelas pisał, że porządek ten „był zawsze uważany za ostatni ze wszystkich, nie przyczynia się bowiem w żaden sposób do zrozumienia rzeczy, które się omawia" 65 - w przeciwieństwie do umotywowanej gramatycznie derivatio albo porządku onomazjologicznego (tematycznego). Poza słownikami dziedzinowymi, ograniczonymi do jednego tematu, istniały zatem słowniki i inne dzieła leksykograficzne uszeregowane według kategorii semantycznych $^{66}$. Dotyczy to szczególnie dzieł o przeznaczeniu pedagogicznym, takich jak wspomniane już Nomina multarum rerum anglice Aelfrica z Canterbury.

$\mathrm{Na}$ bazie wielkich słowników Papiasa, Osberna, Huguciona i Jana de Balbis powstawały kolejne, przy czym można wyróżnić dwa nurty kompilacyjne: z jednej strony erudycyjny, w którym zachowywano albo nawet amplifikowano olbrzymi aparat gramatyczny, etymologiczny i encyklopedyczny - wykształcony od czasów antycznych i ewentualnie wzbogacony odniesieniami do realiów współczesnych, z drugiej zaś strony nurt praktyczno-pedagogiczny, w którym obszerny materiał wielkich słowników, przede wszystkim Catholiconu, skracano i upraszczano na użytek osób uczących się łaciny ${ }^{67}$. $\mathrm{W}$ tym drugim nurcie celem nie było już przedstawienie słownictwa rzadkiego i trudnego, lecz również tego codziennego i powszechnego, opatrzonego podstawowymi informacjami gramatycznymi i - jako dodatkową pomocą - glosami tłumaczeniowymi w języku wernakularnym ${ }^{68}$. Właśnie przez glosowanie następował rozwój słowników wielojęzycznych, takich jak łacińsko-francuski Aalma z drugiej połowy

\footnotetext{
56 A. della Casa, Les glossaires et les traités de grammaires du Moyen Âge, w: La lexicographie du latin médiéval et ses rapports avec les recherches actuelles sur la civilisation du Moyen âge, „Bulletin des bibliothèques de France”, 8, 1982, s. 41.

57 O. Weijers, Lexicography in the Middle Ages, s. 144; J.-C. Boulanger, Les inventeurs de dictionnaires, s. 293.

${ }^{58}$ C. Buridant, Lexicographie et glossographie médiévales, s. 26.

${ }_{59}$ M. Plezia, Dzieje leksykografii tacińskiej w Polsce, s. VI.

${ }^{60} \mathrm{~K}$. Miethaner-Vent, L'alphabétisation, s. 111.

${ }_{61}$ T. Piotrowski, Zrozumieć leksykografię, Warszawa 2001, s. 44-46.

${ }^{62}$ O. Weijers, Dictionnaires et répertoires au moyen âge, s. 15 (thum. własne).

${ }^{63}$ C. Buridant, Lexicographie et glossographie médiévales, s. 20.

${ }^{64}$ K. Miethaner-Vent, L'alphabétisation, s. 111.

${ }^{65}$ C.F. de Vaugelas, Remarques sur la langue française, 1647, przedmowa, s. XXXIII; cyt. za: J.-C. Boulanger, Les inventeurs de dictionnaires, s. 223 (tłum. własne).

${ }^{66}$ C. Buridant, Lexicographie et glossographie médiévales, s. 14.

${ }^{67}$ Tamże, s. 31; A. Rossebastiano Bart, Alle origini della lessicografia italiana, s. 124.

${ }^{68}$ C. Buridant, Lexicographie et glossographie médiévales, s. 21, 31.
} 
XIV w., będący skrótem Catholiconu. Nurt „demokratyzujący” leksykografię łacińską pojawił się również na ziemiach niemieckich, gdzie jego reprezentantami były słowniki przeznaczone dla szerokiego odbiorcy i zawierające włączone w tekst słownika glosy niemieckie ${ }^{69}$ : Lucianus Henryka z Ratyzbony (druga połowa XIV w.), Vocabularius brevilogus lub breviloquus ${ }^{70}$ (ostatnia ćwierć XIV w.) oraz Vocabularius Ex quo (ok. 1400 r.). Ten ostatni cieszył się szczególną popularnością: zachował się w 280 rękopisach, miał również wiele wydań drukiem w drugiej połowie XV w. ${ }^{71}$ Podobnie jak Lucianus, znany był również na ziemiach polskich ${ }^{72}$. Należy podkreślić, że poszczególne kopie Vocabularius Ex quo bardzo różniły się między sobą zależnie od regionu, tak że niemal każdy rękopis może być uznany za nową wersję ${ }^{73}$. Jest to wyjątkowo wymowny przykład dużej zmienności geograficznej i indywidualnej słowników, która zaczęła zanikać dopiero wraz z rozwojem druku ${ }^{74}$.

Poza układami onomazjologicznymi i semazjologicznymi należy wspomnieć o porządkowaniu wyrazów w takiej kolejności, w jakiej występowały w tekście, do którego odnosił się słownik ${ }^{75}-\mathrm{np}$. w Biblii. Przykładem jest tu jedna z dwóch części VIII-wiecznego glosariusza z Reichenau ${ }^{76}$, ale i znacznie późniejszy, XIV-wieczny Mammotrectus franciszkanina Jana Marchesiniego. Wydaje się, że największy rozgłos zyskał on w literaturze czeskiej i polskiej. W drodze glosowania i kolejnych opracowań na jego podstawie powstawały słowniki łacińsko-wernakularne (łacińsko-czeskie zachowały się w dziewiętnastu rękopisach ${ }^{77}$, łacińsko-polskie w dwóch ${ }^{78}$ ), a słowo „mamotrekt” („mammotrekt”, „mamotrept”) stało się - chyba niesłusznie - rzeczownikiem pospolitym oznaczającym słownik biblijny, niekoniecznie czerpiący z dzieła Marchesiniego ${ }^{79}$.

Rodzi się pytanie o funkcje i funkcjonowanie leksykografii w średniowiecznym życiu intelektualnym i społecznym. Ponieważ w rozwoju leksykografii na świecie słowniki jednojęzykowe przeważnie powstają wcześniej niż dwujęzyczne, fakt, że początki słowników języków europejskich wiążą się z łacińsko-wernakularnymi glosariuszami może wydawać się pewną anomalią ${ }^{80}$. Nie należy jednak patrzeć na leksykografię średniowieczną przez pryzmat współczesnego krajobrazu językowo-kulturowego Europy oraz również współczesnego - i upraszczającego - przekonania o naturalnej jednojęzyczności kultury, czy wręcz równoważności język-kultura. W kulturę średniowiecza wpisana była dyglosja ${ }^{81}$, a łacina nie

69 Tamże, s. 28.

${ }^{70}$ Nazwa Vocabularius brevilogus jest starsza, breviloquus to zrelatynizowana forma, którą wprowadził Jan Reuchlin w momencie wydania słownika drukiem w 1475 r.; K. Voleková, Česká lexikografie, s. 20 n.

${ }^{71}$ B. Schnell, Le Vocabularius Ex quo, principal dictionnaire latin-allemand de la fin du Moyen Âge, „Lexique 4. La lexicographie au Moyen Âge", 1986, s. 81.

${ }^{72}$ M. Plezia, Dzieje leksykografii łacińskiej w Polsce, s. VI n. Lucianus pojawia się m.in. w rękopisie BN sygn. BOZ 62 z lat 1400-1430 oraz w rękopisie BJ nr 228 z 1437 r. A. Brückner (Z rękopisów petersburskich, cz. 2: Średniowieczne słownictwo polskie, „Prace Filologiczne”, 5, 1895, s. 5) pisał o „kilkunastu” kopiach Vocabulariusa Ex quo, które znalazł w Bibliotece Publicznej w Petersburgu, i wydał wybrane polskie glosy z sześciu z nich, które później zaginęły lub spłonęły w czasie wojny; zob. <http://eazpp.bn.org.pl/eazpp/files/dabrowka/eazpp-zabytki-polskie-do-1500.pdf> [dostęp: 23.02.2019]. M. Leńczuk (tenże, Zapisy polskie, s. 109) podaje dziewięć zachowanych do dzisiaj kopii tego słownika. Zachowane rękopisy w większości nie są wcześniejsze niż połowa XV w., najstarszy jest kodeks Biblioteki Ossolineum 1630/I z 1429 r.

73 C. Buridant, Lexicographie et glossographie médiévales, s. 26.

74 Tamże, s. 33.

75 A. Rossebastiano Bart (taż, Alle origini della lessicografia italiana, s. 119) określa go jako ordinamento casuale, czyli „porządek przypadkowy”, i ocenia, że jest on jeszcze daleki od jasnej intencji leksykograficznej.

${ }^{76}$ K. Voleková, Česká lexikografie, s. 314.

77 Szesnastu pełnych kopiach i trzech fragmentach; tamże, s. 67.

${ }_{78}$ Mamotrekty staropolskie, cz. 1-3, oprac. W. Żurowska-Górecka, V. Kyas, Wrocław 1977-1980.

79 A. Brückner (np. tenże, Z rękopisów petersburskich) i M. Leńczuk (tenże, Zapisy polskie) mianem polskich mamotrektów określają krótkie słowniczki biblijne (do kilkudziesięciu wyrazów), nieraz opatrzone jedynie sporadycznymi glosami polskimi.

${ }^{80}$ C. Boisson, P. Kirtchuk, H. Béjoint, Aux origines de la lexicographie. Les premiers dictionnaires monolingues et bilingues, „International Journal of Lexicography”, 4, 1991, nr 4, s. 284; za: J.-C. Boulanger, Les inventeurs de dictionnaires, s. 249.

${ }^{81}$ G. Thomas, The Role of diglossia in the Development of the Slavonic Literary Languages, „Slavistična revija”, 37, 1989, $\mathrm{nr}$ 1, s. 273-282. Dyglosja to sytuacja, w której społeczność posługuje się dwoma językami o różnym statusie: potocznym językiem ojczystym oraz językiem elitarnym, poznawanym w drodze formalnej edukacji. W niektórych kontekstach w średniowieczu można mówić o trilingwizmie, czyli współistnieniu trzech języków: łaciny uczonej, łaciny potocznej i języka wernakularnego; zob. P. Bourgain, La fin du moyen âge. Le recul du latin, w: Le Latin médiéval, Turnhout 2005, s. 63-65. 
była wobec niej czymś zewnętrznym. Wręcz przeciwnie, jako język religii i wiary oraz (przez długi czas) jedyny język piśmiennictwa, stanowiła integralną i żywą część tej kultury, i to część elitarną - do niej należeli litterati, głównie duchowni, dla których łacina była językiem „oficjalnym i profesjonalnym” ${ }^{2}$. Właśnie oni mogli być zainteresowani tworzeniem słowników i korzystaniem z nich ${ }^{83}$. Słowniki jako dydaktyczne narzędzie językowe ułatwiały lub wręcz umożliwiały uczestnictwo w łacińskojęzycznej kulturze religijnej i intelektualnej, na różnych jej poziomach ${ }^{84}$. Krąg odbiorców średniowiecznych słowników był szeroki i obejmował zarówno uczonych erudytów, dla których największą wartość miały obszerne objaśnienia etymologiczne i encyklopedyczne zawarte np. w Catholiconie, jak i simpliciores, potrzebujący prostszego i zwięźlejszego wykładu, szczególnie na użytek szkolny ${ }^{85}$.

Przypomnijmy, że pierwsze łacińskie słowniki były jednojęzykowe, i to one w dużej mierze przyczyniły się do wykształcenia kulturowego pojęcia słownika ${ }^{86}$. Glosariusze „właściwe” - glossae collectae - służyły jako pomoc w zrozumieniu tekstów, w tym przede wszystkim tekstu najważniejszego, czyli Biblii. Po dekontekstualizacji i kolejnych amplifikacjach zapewniały swoim użytkownikom aparat pojęciowy i specjalistyczną terminologię ułatwiającą lekturę i studiowanie literatury teologicznej, a po wprowadzeniu konsekwentnego porządku alfabetycznego słowniki mogły już służyć jako doraźna pomoc w zrozumieniu, a może i przekładzie ${ }^{87}$ dowolnych tekstów. Podobną rolę w obrębie właściwych dyscyplin pełniły słowniki dziedzinowe, np. prawnicze albo medyczne.

Zarówno te ostatnie, jak i nominalia służyły jako podręczniki wspomagające naukę języka. Wyszukiwanie słów w celu rozwiązania konkretnego problemu ze zrozumieniem tekstu było w takich słownikach utrudnione, jednak cel, jaki im przyświecał, był nieco inny: dzięki nim uczeń miał przyswoić określone słownictwo tak, by w późniejszym życiu móc się nim posługiwać bez konieczności konsultowania się ze słownikiem. Porządek rzeczowy czy wierszowana forma (w dziełach takich jak Dictionarius metricus Jana z Garlandii ${ }^{88}$ lub XIV-wieczne łacińsko-czeskie Bohemarz i Glosarz napisane leoninem przez Bartłomieja z Chlumca ${ }^{89}$ ) stanowily cenne pomoce mnemotechniczne.

Podobną, lecz odrębną kategorię stanowią słowniki opracowane według metody derivatio. Tu również celem było opanowanie języka, dokonywało się ono jednak poprzez poznanie określonych zasad gramatycznych. Derywacje i etymologie budowały sieć powiązań między wyrazami, przedstawiając język jako kompleksowy system, czego nie robiły lakoniczne glosariusze.

Słowniki wielojęzyczne wywodziły się z jednojęzykowych łacińskich, które opatrywano coraz częstszymi i coraz bardziej systematycznymi glosami w językach wernakularnych. Proces ten nastąpił w krajach germańskich i celtyckich wcześniej niż w krajach romańskich, gdzie związki między łaciną a vulgaris były na tyle ścisłe, że przez dłuższy czas nie postrzegano ich jako odrębnych języków ${ }^{90}$. Mimo to również tam już w VII-IX w. występowały znaczące różnice między językiem potocznym a językiem tekstów $^{91}$. Taka ewolucja nie zachodziła rzecz jasna na terenach, gdzie łacina wkroczyła dopiero wraz

${ }^{82}$ M. Plezia, Dzieje leksykografii tacińskiej w Polsce, s. V; A. Guriewicz, Problemy średniowiecznej kultury ludowej, thum. Z. Dobrzyniecki, Warszawa 1987, s. 15 n.

${ }^{83}$ Por. J. Domański, Leksykografia łacińska a kultura umysłowa średniowiecza [rec.: La lexicographie du latin médiéval et ses rapports avec les recherches actuelles sur la civilisation du moyen âge. Colloque international du Centre national de la recherche scientifique, Paris, 18-21 octobre 1978, Paris 1981], „Przegląd Tomistyczny”, 3, 1987, s. 219: „Może sama historia i sama historyczna rola tego języka wymaga, aby słownik łaciny średniowiecznej, bardziej niż słownik jakiegokolwiek innego języka, przypominał fachowe leksykony? Wszak łacina rychło stała się w średniowieczu elitarnym językiem inteligencji i intelektualistów [...]. Była zatem nade wszystko językiem fachowców, wyspecjalizowanym językiem szczególnych, elitarnych dziedzin życia".

${ }^{84}$ „Latin, [...] passport to religious and cultural elevation”; T. McArthur, Thematic Lexicography, s. 163.

${ }^{85}$ C. Buridant, Lexicographie et glossographie médiévales, s. 28.

${ }^{86}$ Tamże, s. 20.

${ }^{87}$ Tamże, s. 13; B. Schnell, Le Vocabularius Ex quo, s. 82.

${ }^{88}$ C. Buridant, Lexicographie et glossographie médiévales, s. $15 \mathrm{n}$.

${ }^{89}$ K. Voleková, Česká lexikografie, s. 152 n.

90 J.A.H. Murray, The Evolution of English Lexicography, London 1900, s. 8 n.

91 J.-C. Boulanger, Les inventeurs de dictionnaires, s. 227; D.A. Sikorski, Filologia łacińska średniowiecza, w: Vademecum historyka mediewisty, red. J. Nikodem, D.A. Sikorski, Warszawa 2012, s. 120. 
z chrystianizacją, np. w Polsce, jednak końcowa sytuacja dyglosji była podobna: w całej Europie łacina, jako język o ustabilizowanej gramatyce i ortografii oraz bogatym zasobie pojęciowym ${ }^{92}$, była jednocześnie językiem elitarnym, poznawanym w drodze formalnej edukacji, oraz językiem żywym, zmieniającym się również pod wpływem miejscowych języków wernakularnych ${ }^{93}$. Jeszcze w słownikach dwujęzycznych łacina przez długi czas stanowiła język wyjściowy, języki wernakularne pełniły zaś niejako rolę służebną. Ich pojawienie się świadczyło jednak o stopniowym wzroście ich znaczenia jako języków odniesienia oraz o ich rozwoju pojęciowym ${ }^{94}$. Proces ten miał odmienną dynamikę w różnych częściach Europy: np. we Francji toczył się już w XIII ${ }^{95}$, a w Polsce dopiero w XV w. ${ }^{96}$, i do tej pory pozostaje słabo rozpoznany.

Dotychczasowe badania nad polskimi słownikami sprzed 1500 r. prowadzone były niemal wyłącznie przez językoznawców, którzy traktowali je jako źródło do poznania staropolszczyzny, w mniejszym stopniu zaś jako świadectwo życia intelektualnego. Dlatego też badano niemal wyłącznie zawarte w nich polskie słownictwo, nie zaś stosowane w nich metody leksykograficzne. Podejście to odzwierciedla np. postępowanie Aleksandra Brücknera, który wydawał słowniki wspólnie z polskimi glosami do łacińskich tekstów, pomijając czasem niektóre łacińskie hasła i podając jedynie polskie odpowiedniki ${ }^{97}$.

Sporządzenie wyczerpującej listy wszystkich średniowiecznych słowników zachowanych na ziemiach polskich, która obejmowałaby również informację o ich wydaniach, wykracza poza ramy niniejszej pracy. W tym miejscu należy ograniczyć się do zasygnalizowania, że choć polska leksykografia pojawiła się dopiero w XV w., wykazywała się jednak względnym bogactwem i różnorodnością. Interesującym przykładem jest kodeks Biblioteki Publicznej w Petersburgu sygn. Lat.I.F.ch.254, pochodzący z 1455 r. ${ }^{98}$ Zawierał on rozmaite zabytki leksykograficzne: dzieło Huguciona, jakiś słownik łaciński, alfabetyczny słownik łacińsko-polski do litery e, sformułowania „wybrane z przywilejów”, grupy haseł ułożonych przedmiotowo (de consanguineitate, de dignitatibus, de animalibus), wyrazy z psałterza, listę czasowników złożonych (ułożoną gniazdowo, według metody derywacji: kolejno złożenia z putare, hibere, mittere itd.) oraz słownik rymowany zaczynający się od haseł fauilla - pyrzyna, annona - yarzyna.

XV-wieczna leksykografia w Polsce obejmowała zatem zarówno działalność rodzimą (liczne drobne słowniczki notowane na pustych kartach lub okładkach kodeksów, słowniki dziedzinowe, np. botaniczne Antibolomenum Jana Stanki z 1472 r.), jak i recepcję wielkich, erudycyjnych słowników zachodnioeuropejskich (np. Catholiconu) oraz słowników o węższym zakresie (jak przejęty za pośrednictwem czeskim Mammotrectus) i przeznaczeniu pedagogicznym (np. Vocabularius Ex quo). Na ziemiach polskich poddawane były kolejnym glosowaniom, kompilacjom, adaptacjom i modyfikacjom, które wciąż pozostają słabo przebadane, pomimo postulatu Mariana Plezi sprzed blisko 60 lat ${ }^{99}$.

\section{Wokabularz trydencki jako zabytek leksykograficzny}

\subsection{Kodeks trydencki}

Przed analizą wokabularza konieczne jest przyjrzenie się kodeksowi, którego stanowi część. Odnaleziony przez Edmunda Winklera w Archiwum Kapituły w Trydencie rękopis o sygnaturze 114 został

92 M. Plezia, Dzieje leksykografii łacińskiej w Polsce, s. V; D.A. Sikorski, Filologia łacińska średniowiecza, s. 122.

${ }^{93}$ K. Weyssenhoff-Brożkowa, Wplyw polszczyzny na łacinę średniowieczna w Polsce, Kraków 1991, s. 5-9.

94 C. Buridant, Lexicographie et glossographie médiévales, s. 20.

95 J.-C. Boulanger, Les inventeurs de dictionnaires, s. 227; P. Bourgain, La fin du moyen âge. Język francuski był w tym czasie coraz częściej używany np. w administracji, co w przypadku języka polskiego długo jeszcze nie miało miejsca.

${ }_{96}$ M. Plezia, Dzieje leksykografii tacińskiej w Polsce, s. VI.

${ }^{97}$ Zob. np. A. Brückner, Neue Quellen zur Geschichte des polnischen Sprache und Literatur, „Archiv für slavische philologie”, 14, 1892, s. 481-511.

98 Tamże, s. 484-496; A. Brückner, Z rękopisów petersburskich, s. 17. Rękopis zaginął i obecnie znany jest tylko z opisu A. Brücknera i jego fragmentarycznego wydania; zob. J. Kaliszuk, Codices deperditi. Średniowieczne rękopisy łacińskie Biblioteki Narodowej utracone w czasie II wojny światowej, t. 2: Katalog rękopisów utraconych, cz. 1, Wrocław 2016, s. 383 n.

${ }_{99}$ M. Plezia, Dzieje leksykografii łacińskiej w Polsce, s. VI. 
wydany w 1960 r. jako Liber disparata antiqua continens ${ }^{100}$, zgodnie z późnym zapisem na okładce. Liczy on 81 kart i poza dwoma wpisami na k. 65v (nr 231 i 232 ${ }^{101}$ ) w całości jest spisany jedną ręką, choć w dalszej części kodeksu pismo staje się mniej staranne ${ }^{102}$. Znaki wodne na papierze pozwalają datować go na lata $1408-1423^{103}$. Zawiera 96 dokumentów i 178 listów, powstałych przed 1416 r. i pochodzących w dużej części z kancelarii Władysława Jagiełły, choć występują w nim również teksty ułożone - w rzeczywistości lub rzekomo - przez urzędników, sędziów, rycerzy, duchownych czy mieszczan ${ }^{104}$. Niektóre z dokumentów i listów są fikcyjne ${ }^{105}$, a w wielu tekstach pominięto daty oraz zastąpiono inicjałami nazwy miejscowości i imiona osób. Jest to zgodne z praktyką tworzenia formularzy, których celem - w przeciwieństwie do kopiariuszy czy libri privilegiorum - było nie tyle zachowanie kopii konkretnych pism, co zebranie wzorów rozmaitych typów dokumentów i korespondencji, które służyły jako ćwiczenia stylistyczne i mogły być pomocne przy redagowaniu kolejnych tekstów (chociaż badacze wysuwają wątpliwości co do rzeczywistego użytkowania formularzy w pracy kancelaryjnej) ${ }^{106}$. Dlatego też kodeks jest w literaturze nazywany formularzem trydenckim lub formularzem Aleksandra ${ }^{107}$, mimo zastrzeżeń kuratorów wydania, którzy proponowali zaklasyfikować kodeks trydencki jako silva rerum. Argumentowali oni, że nie mieści się on w kategorii formularzy, ponieważ zawarte w nim teksty mają często nikłą wartość dyplomatyczną i dotyczą niepowtarzalnych sytuacji, a przy tym obok dokumentów i listów pojawiają się również schematy teorii retorycznych, które dla pisarza byłyby nieprzydatne ${ }^{108}$.

Oprócz wspomnianych już listów i dokumentów oraz schematów teorii retorycznych (nr 211 i 212) kodeks zawiera spis zwrotów adresatywnych uzależnionych od godności adresata (nr 214), a także najbardziej nas tu interesujący wokabularz trydencki (zapisany na k. 71r-74v, nr 260) oraz dwa kazania (lub fragmenty kazań) w języku czeskim, z których jedno otwiera, a drugie zamyka kodeks. E. Winkler nie włączył wokabularza i tekstów czeskich do wydania całego formularza, zamieszczając tylko ich fotokopie. Zostały one wydane osobno ${ }^{109}$ i może z tego względu szczególnie na temat tekstów czeskich w literaturze można znaleźć sprzeczne informacje. Sam E. Winkler określił je jako alokucje traktujące o wysokiej godności urzędu biskupa i znikomości tego świata ${ }^{110}$, kuratorzy wydania formularza pisali zaś o przedmowie (praefatio) i epilogu (epilogus) w jakimś języku słowiańskim, polskim albo czeskim $^{111}$. Być może na tej podstawie Irena Sułkowska-Kurasiowa wspomniała o „kazaniach po polsku” ${ }^{112}$.

Ze względu na kompilacyjny charakter kodeksu trydenckiego ustalenie jego autora nastręcza pewnych trudności. Słuszniej byłoby mówić o redaktorze, który zgromadził teksty pochodzące z różnych źródeł, być może niektóre przeredagowując, a inne tworząc od podstaw ${ }^{113}$. Trudno to jednak ustalić ze względu

100 „Liber disparata antiqua continens”. Alexandro Masoviensi episcopo Tridentino dicatus, wyd. E. Winkler, Elementa ad fontium editiones, t. 2, Romae 1960.

101 Numeracja według wydania E. Winklera.

102 C. Lanckorońska, W. Meysztowicz, Adnotationes curatorum editionis, w: „Liber disparata antiqua continens”, s. XI.

${ }^{103}$ E. Winkler, Praefatio, w: tamże, s. VI n.

${ }^{104}$ A. Larczyńska, Prawdziwe czy zmyślone? Źródła epistolarne i dokumentowe w formularzu księcia mazowieckiego Aleksandra. Próba rekonesansu badawczego, „Studia z Dziejów Średniowiecza”, 18, 2014, s. 143, 154.

105 Według obliczeń A. Larczyńskiej (tamże, s. 152) kodeks zawiera 208 autentycznych pism (119 listów i 89 dokumentów) oraz 66 fikcyjnych (59 listów i 7 dokumentów).

106 M. Koczerska, Fikcja i rzeczywistość w formularzach polskich, w: Literatura i kultura polskiego średniowiecza, red. P. Buchwald-Pelcowa, J. Pelc, Warszawa 1995, s. 23; G. Klimecka, Z historii tworzenia języka dokumentu polskiego wieków średnich. Formularz ciechanowski, Warszawa 1997, s. 13, 18

107 A. Larczyńska, Prawdziwe czy zmyślone?, s. 152.

${ }^{108}$ C. Lanckorońska, W. Meysztowicz, Adnotationes curatorum editionis, s. VIII.

109 Wydanie wokabularza: Il più antico dizionario latino-polacco (del 1424), wyd. E. Winkler, „Ricerche Slavistiche”, 8, 1960, s. 96-111; wydanie tekstów czeskich: Due testi cechi scoperti da E. Winkler nell'Archivio del Capitolo Trentino, wyd. B. Meriggi, „Ricerche Slavistiche”, 8, 1960, s. 112-125.

${ }_{110}$ Il più antico dizionario latino-polacco, s. 111.

111 C. Lanckorońska, W. Meysztowicz, Adnotationes curatorum editionis, s. X.

112 I. Sułkowska-Kurasiowa, Dokumenty królewskie i ich funkcja w państwie polskim za Andegawenów i pierwszych Jagiellonów, Warszawa 1977, s. 91.

113 C. Lanckorońska, W. Meysztowicz, Adnotationes curatorum editionis, s. X. 
na wielowarstwowość genetyczną średniowiecznych tekstów, nieraz wielokrotnie przepisywanych przez kolejnych kopistów, z których każdy był „mutatorem” tekstu „źródłowego” ${ }^{114}$. Sytuację komplikuje fakt, że ostateczny redaktor - ten, spod którego ręki wyszedł niemal cały kodeks trydencki - niekoniecznie był tożsamy z późniejszym właścicielem i użytkownikiem rękopisu. Jest to tym bardziej prawdopodobne, jeśli właścicielem był - tak jak się to przeważnie przyjmuje w literaturze - Aleksander mazowiecki (1395-1444), syn Siemowita IV i Aleksandry Olgierdówny, a zatem siostrzeniec Władysława Jagiełły. Bliskie pokrewieństwo z królem niewątpliwie ułatwiło mu karierę duchowną: już w 1409 r. otrzymał prowizję na prepozyturę płocką, której jednak nigdy nie udało mu się objąć, w 1414 r. zaś prowizję na prepozyturę gnieźnieńską ${ }^{115}$. Również w 1414 r. Jagiełło zaproponował jego kandydaturę na biskupstwo poznańskie, ostatecznie jednak stanowisko to objął Andrzej Łaskarz ${ }^{116}$. W 1417 r. Aleksander zapisał się na Uniwersytet Krakowski ${ }^{117}$, a w 1422 r. został jego rektorem. Ponieważ nie miał żadnego stopnia naukowego, wybór ten był niezgodny z prawem i motywowany najpewniej chęcią pozyskania przychylności Jagiełły ${ }^{118}$, choć w rekomendacji wygłoszonej przy objęciu rektoratu - notabene piętnującej wybory, w których elektorzy kierują się „carne, favore vel sanguine” - wychwala się zamiłowanie księcia do życia społecznego oraz jego silną rękę ${ }^{119}$. Po nominacji biskupiej Zbigniewa Oleśnickiego w 1423 r. mazowiecki książę objął po nim kanonię gnieźnieńską, a w październiku tego samego roku otrzymał od papieża nominację na biskupstwo w Trydencie ${ }^{120}$. Doszło do tego w wyniku trwającego cztery lata (od śmierci poprzedniego biskupa) sporu o obsadzenie biskupstwa trydenckiego między papieżem Marcinem V a Habsburgami z Tyrolu, którzy chcieli zachować kontrolę nad Trydentem. Kandydatura Aleksandra została prawdopodobnie zaproponowana za wstawiennictwem jego siostry Cymbarki, która od 1412 r. była żoną Ernesta Żelaznego. Powinowactwo z Habsburgami oraz, być może, chęć Marcina V, by załagodzić stosunki z Polską po Satyrze Jana Falkenberga, doprowadziły Aleksandra do godności biskupiej ${ }^{121}$. Do Trydentu wyruszył wiosną 1424 r., po przyjęciu wyższych święceń, a ingresu dokonał 26 czerwca, w uroczystość św. Wigiliusza, patrona miasta; święcenia biskupie przyjął dopiero we wrześniu $1425 \mathrm{r}$. ${ }^{122}$ Za swoich rządów próbował uniezależnić księstwo trydenckie od zwierzchnictwa tyrolskich Habsburgów ${ }^{123}$, zwołał synod diecezjalny i zarządził wizytacje parafii ${ }^{124}$. Za zasługę poczytuje mu się również kodyfikację prawa trydenckiego $\mathrm{w}$ formie tzw. Statutów Aleksandryjskich, które funkcjonowały do 1796 r. ${ }^{125}$ Trudno jednak stwierdzić, jaki był jego udział w ich opracowywaniu, skoro zostały skompilowane już w 1425 r. i wydaje się, że nowy biskup jedynie je zatwierdził ${ }^{126}$.

114 T. Mika, Genetyczna wielowarstwowość i złożoność tekstów staropolskich a ich badania historycznojęzykowe. Rekonesans, „Biuletyn Polskiego Towarzystwa Językoznawczego”, 68, 2013, s. 132, 137.

115 A. Radzimiński, Prałaci i kanonicy kapituly katedralnej płockiej w XIV i I pot. XV w. Studium prozopograficzne, t. 1: Prałaci, Toruń 1991, s. 60; L. Zygner, Piastowie mazowieccy na stolicach biskupich, w: Dziedzictwo ksiażat mazowieckich. Stan badań i postulaty badawcze, red. J. Grabowski, R. Mroczek, P. Mrozowski, Warszawa 2017, s. 146.

${ }^{116}$ L. Bąkowski, Książę mazowiecki Aleksander, biskup trydencki, Przegl. Hist., 16, 1913, nr 1, s. 6-7; J.W. Woś, Aleksander Mazowiecki - biskup trydencki (1423-1444), „Saeculum Christianum”, 6, 1999, nr 2, s. 20; tenże, Alessandro di Masovia, vescovo di Trento e patriarca di Aquilea (1400-1444), Roma-Trento 1998, s. 9.

${ }_{117}$ Metryka Uniwersytetu Krakowskiego z lat 1400-1508, t. 1, wyd. A. Gąsiorowski, T. Jurek, I. Skierska, Kraków 2004 , s. 91.

118 L. Zygner, Piastowie mazowieccy, s. 146.

119 Mowa znajduje się w rękopisie BJ 1629, k. 333v-336r; omówienie w: M. Kowalczyk, Krakowskie mowy uniwersyteckie z pierwszej połowy XV wieku, Kraków 1970, s. 39; J.W. Woś, Aleksander Mazowiecki, s. 22.

${ }^{120}$ L. Bąkowski, Ksiązę mazowiecki Aleksander, s. 7, 12; J.W. Woś, Alessandro di Masovia, s. 13.

${ }^{121}$ L. Bąkowski, Książę mazowiecki Aleksander, s. 11; J.W. Woś, Aleksander Mazowiecki, s. 18; tenże, Alessandro di Masovia, s. 13.

${ }^{122}$ L. Zygner, Piastowie mazowieccy, s. 148 n.

123 Tamże, s. 150; J.W. Woś, Aleksander Mazowiecki, s. 24.

124 J.W. Woś, Alessandro di Masovia, s. 33.

125 L. Zygner, Piastowie mazowieccy, s. 150.

${ }^{126}$ Zob. B. Andreolli, Per una campionatura delle rivolte cittadine e rurali nel Trentino medievale, „Annali dell Istituto »Alcide Cervi«”, 16, 1994, s. 39: „nel 1425 [...] compilazione dei nuovi statuti, approvati dal vescovo Alessandro di Mazovia e perciò detti Alessandrini". 
Aleksander popadł w konflikt z poddanymi, którzy w skardze z 1436 r. skierowanej do Fryderyka IV Habsburga zarzucali mu m.in. faworyzowanie Polaków ${ }^{127}$, sprzyjanie Żydom, fałszowanie dokumentów i rozwiązłość ${ }^{128}$. Niemożność sprawowania władzy w Trydencie z powodu tego konfliktu mogła być obok poparcia dla koncyliaryzmu - jednym z powodów, dla których Aleksander brał aktywny udział w soborze bazylejskim ${ }^{129}$. Z rąk soboru i antypapieża Feliksa V otrzymywał kolejne godności, choć niektóre z nich były tylko tytularne: w 1439 r. został patriarchą Akwilei, w 1440 r. legatem papieskim do króla Fryderyka III Habsburga oraz Węgier, Czech, Polski, Moraw, Austrii i Akwilei, a także kardynałem tytułu św. Wawrzyńca w Damaszku, w 1442 r. zaś - biskupem Chur i prepozytem kościoła św. Stefana w Wiedniu ${ }^{130}$. Zmarł 2 VI $1444 \mathrm{w}$ Wiedniu, nie spełniwszy misji powierzonej mu przez sobór ${ }^{131}$.

Za uznaniem Aleksandra za właściciela kodeksu trydenckiego ${ }^{132}$ przemawiała data powstania rękopisu oraz znalezienie go w Trydencie. Na tej podstawie - a także z uwagi na to, że skopiowanie dokumentów do kodeksu wymagało dostępu do kancelarii królewskiej - August Steffen ${ }^{133}$ stwierdził, że młody książę mazowiecki osobiście zebrał spisany w kodeksie materiał, odzwierciedlający zarówno jego bliskie związki z królem ${ }^{134}$, jak i powiązania uniwersyteckie. O tych ostatnich świadczyłby żartobliwy list studentów do rektora (nr 259), jak i przydatność formularza, listy zwrotów adresatywnych i słownika w wykładaniu na uniwersytecie. Z uwagi na najprawdopodobniej wyłącznie tytularny charakter godności rektorskiej Aleksandra oraz brak dowodów na skłonność księcia do wytężonej pracy intelektualnej ${ }^{135}$ teza A. Steffena wydaje się jednak wątpliwa. Nie wykluczając związku kodeksu z Aleksandrem, Stanisław Urbańczyk powątpiewał, by „taki pan miał czas na kopiowanie dokumentów”136; podobnie Agata Larczyńska twierdzi, że „książę, zajęty karierą kościelną, raczej nie mógł osobiście układać i kopiować pism wchodzących w skład rękopisu" ${ }^{137}$. Natomiast kuratorzy wydania powątpiewali w autorstwo Aleksandra ${ }^{138} \mathrm{z}$ innego powodu, który jednocześnie wydawał się decydującym argumentem za tym, że właścicielem rękopisu był właśnie książę mazowiecki. Chodzi o rzekomą dedykację skierowaną do młodego biskupa, zawartą $\mathrm{w}$ otwierającym kodeks tekście czeskim ${ }^{139}$. Z tego względu powstanie kodeksu datowano na okres między otrzymaniem przez Aleksandra nominacji a jego wyjazdem do Trydentu (koniec 1423 - początek 1424 r. $)^{140}$.

${ }^{127}$ Prawdą jest, że Aleksander przyznawał Polakom, którzy należeli do jego świty, wysokie stanowiska w księstwie trydenckim, a nawet tworzył takie stanowiska specjalnie dla nich, np. prepozyturę dla Stanisława Sobniowskiego; L. Bąkowski, Książe mazowiecki Aleksander, biskup trydencki (dokończenie), Przegl. Hist., 16, 1913, nr 2, s. 131.

128 Tamże; J. Grabowski, Dynastia Piastów mazowieckich, Kraków 2012, s. 524.

129 A. Salina, Polityka książąt mazowieckich wobec władz Kościoła od początku XIV wieku do 1526 roku, Poznań 2011, s. 242 n.

${ }^{130}$ L. Zygner, Piastowie mazowieccy, s. 152.

131 Tamże. Eneasz Sylwiusz Piccolomini, który był protegowanym i przyjacielem Aleksandra, po jego śmierci bardzo krytycznie napisał, że życie biskupa trydenckiego było mało pożyteczne dla soboru; R. Ojrzyński, Obraz Polski i Polaków w pismach Eneasz Sylwiusza Piccolominiego (papieża Piusa II), Warszawa 2014, s. 72.

132 Zob. np. A. Larczyńska, Prawdziwe czy zmyślone?, s. 142: „[kodeks] należał do Aleksandra”.

133 Stowniczek trydencki, wyd. A. Steffen, „Teki Historyczne”, 11, 1960-1961, s. 221-223.

134 „Przypuszczam, że Aleksander zaczął gromadzić materiał dopiero po przeprowadzeniu się do Krakowa i to w porozumieniu z królem, bo od królewskich dokumentów zaczyna się budowa dzieła. Wystarczy popatrzeć na te dokumenty. Taki materiał dostać mógł tylko bliski krewny, któremu król był oddany sercem i duszą"; tamże, s. 222.

135 I. Zarębski, Stosunki Eneasza Sylwiusza z Polska i Polakami, Kraków 1939, s. 29 n.: „nie bardzo interesował się nauką i nie umiał stworzyć w Trydencie ogniska, do którego by ściągały sławy humanistyczne".

136 Wokabularz trydencki, wyd. S. Urbańczyk, „Język Polski”, 42, 1962, nr 1, s. 15; zob. też M. Koczerska, Fikcja i rzeczywistość, s. 38: „[formularze] tworzył niższy personel notarialny kancelarii królewskiej lub biskupiej, zaznaczając przy poszczególnych tekstach ich redaktora".

137 A. Larczyńska, Prawdziwe czy zmyślone?, s. 146.

138 C. Lanckorońska, W. Meysztowicz, Adnotationes curatorum editionis, s. XI

139 „In primo folio voluminis nostri dedicatio invenitur in lingua, quae nobis Polonica videtur: »Reverendo Alexandro, comiti magno«" (tamże, s. VIII); „alokucja o wysokiej godności urzędu biskupa w języku staroczeskim, dedykowana Aleksandrowi z żalem opuszczającemu rodzinny kraj, by objął biskupstwo w Trydencie" (Il più antico dizionario latino-polacco, s. 111); zob. też I. Sułkowska-Kurasiowa, Dokumenty królewskie, s. 91: „sądząc z dedykacji na niej wpisanej, [książka] była własnością księcia mazowieckiego Aleksandra".

140 Il più antico dizionario latino-polacco, s. 111. 
W rzeczywistości domniemana dedykacja to fraza „Cztemy o Alexandru graby velykeho”, która stanowi początek exemplum o Aleksandrze Wielkim przytłoczonym ciężarem korony. Historia ta przytoczona została w ramach kazania, w którym więcej miejsca niż pouczenie dla duszpasterzy (co można by jeszcze skojarzyć z nowo uzyskaną godnością Aleksandra) zajmuje opis Chrystusa jako dobrego pasterza $^{141}$. Tekst zamykający kodeks informuje natomiast nie tyle o marności świata, jak twierdził E. Winkler, ile o zmartwychwstaniu, wychodząc od słów Chrystusa „Modicum et iam non videbitis me et iterum modicum et videbitis me"142 (J 16, 16).

Imię księcia Aleksandra nie pada też w żadnym innym miejscu kodeksu. Również związki z Mazowszem nie są zbyt liczne: spośród 274 dokumentów i listów jedynie dwa (177 - list do Jagiełly i 216 - formularz lokacyjny) pochodzą ponad wszelką wątpliwość z kancelarii księcia Siemowita ${ }^{143}$. Większość osób i miejsc pojawiających się w tekstach wiąże się z Małopolską - często pojawia się Kraków, Sandomierz czy Stary Sącz ${ }^{144}$.

Choć mimo wszystko nie jest wykluczone, że kodeks rzeczywiście był w posiadaniu Aleksandra, to rozluźnienie związku z tą postacią, a przede wszystkim z jego nominacją biskupią, pozwala po pierwsze przesunąć terminus a quo powstania kodeksu nawet do 1416 r. (data najpóźniejszego zawartego W nim dokumentu ${ }^{145}$, a po drugie dopuścić możliwość, że do Trydentu rękopis trafił za pośrednictwem któregoś z członków świty Aleksandra.

Mógł to być Stanisław Sobniowski (zm. 1454), który od 1416 r. wykładał na Wydziale Sztuk Uniwersytetu Krakowskiego, a w semestrze 1419/1420 był dziekanem tego wydziału. Od razu po nominacji biskupiej Aleksandra otrzymał od niego urząd kanclerza księstwa Trydentu i razem z nim pojechał do Włoch. Później został również kanonikiem i prepozytem trydenckim oraz prepozytem płockim, a także posłem na sobór bazylejski, na którym przebywał wraz z Aleksandrem ${ }^{146}$. Fakt, że podarował Uniwersytetowi Krakowskiemu księgi, głównie filozoficzne, Ludwik Bąkowski interpretuje jako dowód zamiłowania Sobniowskiego do nauki ${ }^{147}$. Już po śmierci Aleksandra, w 1446 r., Sobniowski został rektorem Uniwersytetu Krakowskiego ${ }^{148}$.

Innym kandydatem byłby Jakub Zaborowski (zm. 1449), doktor dekretów, wykładowca prawa oraz pięciokrotny rektor Uniwersytetu Krakowskiego (w latach 1420, 1424, 1437, 1444, 1447) - a zatem żartobliwy list od studentów wspomniany przez A. Steffena (nr 259), jeżeli był autentyczny, równie dobrze mógł być adresowany do niego. Również Zaborowski mógłby korzystać z kodeksu jako pomocy dydaktycznej. Do Trydentu przyjechał na zaproszenie Aleksandra dopiero w 1427 r., otrzymując od biskupa kilka prebend ${ }^{149}$. Leszek Zygner właśnie Zaborowskiemu przypisuje zarówno sprowadzenie kodeksu trydenckiego ${ }^{150}$, jak i kodyfikację prawa trydenckiego w formie Statutów Aleksandryjskich ${ }^{151}$, choć szczególnie to ostatnie osiągnięcie jest mało prawdopodobne, skoro zostały one skompilowane już w 1425 r. Zaborowski przebywał zresztą w Trydencie zaledwie dwa lata. W późniejszym okresie brał udział w obradach soboru bazylejskiego ${ }^{152}$.

\footnotetext{
${ }^{141}$ Due testi cechi, s. 112.

142 Tamże, s. 115.

${ }^{143}$ G. Klimecka, Z historii tworzenia języka dokumentu, s. 41. A. Steffen (Stowniczek trydencki, 1960-1961, s. 222) mówi o czterech dokumentach, trudno jednak powiedzieć, na czym opiera to stwierdzenie.

144 C. Lanckorońska, W. Meysztowicz, Adnotationes curatorum editionis, s. IX.

145 Wokabularz trydencki, s. 15.

${ }_{146}$ M. Wolski, Stanisław Sobniowski h. Strzemię, iPSB, <https://www.ipsb.nina.gov.pl/a/biografia/stanislaw-sobniowski-h-strzemie> [dostep: 23.02.2019]; L. Bąkowski, Książę mazowiecki Aleksander, biskup trydencki (dokończenie), s. 130-133.

${ }^{147}$ L. Bąkowski, Książę mazowiecki Aleksander, biskup trydencki (dokończenie), s. 133.

148 M. Wolski, Stanisław Sobniowski.

149 Z. Kozłowska-Budkowa, Jakub z Zaborowa, w: PSB, t. 10, Wrocław 1962-1964, s. 368 n.; L. Bąkowski, Ksiązę mazowiecki Aleksander, biskup trydencki (dokończenie), s. $133 \mathrm{n}$.

${ }^{150} \mathrm{O}$ tym, że Jakub Zaborowski mógł być autorem Wokabularza trydenckiego, wspomniał A. Litwornia, Dante w kulturze staropolskiej: stulecia XV-XVI, „Pamiętnik Literacki”, 81, 1990, nr 2, s. 189.

${ }^{151}$ L. Zygner, Piastowie mazowieccy, s. 151.

${ }^{152}$ L. Bąkowski, Ksiązę mazowiecki Aleksander, biskup trydencki (dokończenie), s. 134.
} 
Do otoczenia Aleksandra należeli również Jan Moszyński, syn Gottarda, kanonik trydencki (co najmniej od 1428) i kustosz płocki, również uczestniczący w obradach soboru i znany z zainteresowania traktatami antyhusyckimi ${ }^{153}$; Jan ze Strzelc zwany de Tenno - od miejscowości, w której był proboszczem $^{154}$; Jan Moszyński, syn Andrzeja, kanonik trydencki w latach 30.; a także Jan Rogala i Mikołaj, syn Piotra „Maskoni”, o których wiadomo tylko, że również byli kanonikami w Trydencie ${ }^{155}$. Oprócz tego Aleksander sprowadzał też do swojego księstwa ludzi świeckich, takich jak gubernator zamku Mikołaj Kunicki oraz Piotr z Kłopoczyna, dowódca wojska trydenckiego i starosta ważnej miejscowości Stenico ${ }^{156}$.

Jeśli to któryś z Polaków z otoczenia Aleksandra przywiózł kodeks do Trydentu, bardziej prawdopodobne jest oczywiście, że był to jeden z duchownych, szczególnie związanych z uniwersytetem. Warto zaznaczyć, że w takim wypadku możliwy jest również późniejszy terminus ad quem powstania kodeksu, nieograniczony już wyjazdem Aleksandra w 1424 r. Bez względu jednak na to, za czyją sprawą kodeks trafił do Trydentu, osoba ta nie musi być tożsama z jego autorem.

Do tej ostatniej roli wysuwa się często kandydaturę Mikołaja z Bolesławia lub Bolesławca ${ }^{157}$, poświadczonego w źródłach jako notariusz królewski w latach 1404-1408, pleban w Dziekanowicach w latach 1412-1414, kanonik kurzelowski w latach 1416-1419, poseł królewski do Rzymu w 1413 r. i uczestnik soboru w Konstancji ${ }^{158}$. Hipoteza o jego autorstwie uzasadniona jest ośmiokrotnym wystąpieniem jego osoby w tekstach formularza ${ }^{159}$. Dodatkowym argumentem może być fakt, że podczas pobytu na soborze w Konstancji Mikołaj przygotował spis najważniejszych godności, co przypomina listę zwrotów adresatywnych z kodeksu trydenckiego (nr 214) ${ }^{160}$.

Jego autorstwo pozostaje jednak niepewne, a przy tym raz jeszcze należy podnieść kwestię wielowarstwowości genetycznej średniowiecznych tekstów. Nie można wszak wykluczyć, że część formularza skompilował rzeczywiście Mikołaj z Bolesławia ${ }^{161}$, a następnie ktoś inny przepisał i uzupełnił jego pracę, np. włączając do kodeksu wokabularz. Pewne wydaje się to, że kodeks powstał w środowisku małopolskim, w kręgach zbliżonych do kancelarii królewskiej oraz uniwersytetu, a na którymś etapie znalazł się w rękach osoby, która zawiozła go na dwór biskupi Aleksandra w Trydencie. Mimo braku dedykacji niewykluczone jest również, że kodeks rzeczywiście przygotowano z okazji wyjazdu Aleksandra, by służył mu pomocą na nowym stanowisku, choć trudno stwierdzić, czy był wykorzystywany ${ }^{162}$.

\subsection{Wokabularz trydencki}

Słownik łacińsko-polski (nr 260 według numeracji w edycji kodeksu trydenckiego), zapisany w dwóch kolumnach na k. $71 \mathrm{v}-74 \mathrm{r}^{163}$ kodeksu, był wydawany trzykrotnie, co stanowi ewenement na tle sporadycznych i fragmentarycznych edycji innych polskich zabytków leksykograficznych. Jako pierwszy ogłosił go E. Winkler ${ }^{164}$, który wydał również fotokopie słownika ${ }^{165}$, następnie A. Steffen ${ }^{166}$, po raz trzeci zaś

153 Tamże, s. 135-137.

154 Tamże, s. $137 \mathrm{n}$.

155 Tamże, s. 139.

156 J.W. Woś, Aleksander Mazowiecki, s. 24.

${ }^{157}$ C. Lanckorońska, W. Meysztowicz, Adnotationes curatorum editionis, s. XI; I. Sułkowska-Kurasiowa, Dokumenty królewskie, s. 92; A. Larczyńska, Prawdziwe czy zmyślone?, s. 153.

158 K. Ożóg, Uczeni w monarchii Jadwigi Andegaweńskiej i Władysława Jagiełty (1384-1434), Kraków 2004, s. 156.

$159 \mathrm{Nr} 9,16,31,37,45,59,62,74$.

160 A. Larczyńska, Prawdziwe czy zmyślone?, s. 146.

161 Warto zauważyć, że jego nazwisko nie pojawia się już po 74. (z 281) zapisie w kodeksie.

162 A. Larczyńska, Prawdziwe czy zmyślone?, s. 152 n.

${ }^{163}$ Karty te należą do serii trzech składek (czwartej, piątej i szóstej), na których widnieją znaki wodne datowane na 1409 r.; E. Winkler, Praefatio, s. VI.

164 Il più antico dizionario latino-polacco, s. 96-111.

165 „Liber disparata antiqua continens”, tab. VI-XVII. Wydania A. Steffena i S. Urbańczyka powstały na podstawie tych właśnie fotokopii.

166 Stowniczek trydencki, 1960-1961, s. 221-243. 
- z uwagi na niewielką dostępność poprzednich edycji oraz zawarte w nich błędy - S. Urbańczyk ${ }^{167}$. Mimo polemiki z tym ostatnim podjętej przez A. Steffena ${ }^{168}$, wydanie S. Urbańczyka - z późniejszymi poprawkami ${ }^{169}$ - jest traktowane w literaturze jako definitywne i na nim też opiera się niniejszy artykuł. $\mathrm{Z}$ niego również pochodzi zwyczajowa nazwa zabytku - wokabularz trydencki.

Wokabularz zawiera 504 hasła $^{170}$, z których 64 są całkowicie łacińskie, bez polskich odpowiedników. Ma formę glosariusza, w którym wyjściowe są zawsze wyrazy łacińskie; wyrazy polskie służą jako objaśnienia, czasem wkomponowane wprost we frazy lacińskie, np. 231. garitus sczeboth avium ${ }^{171}$ albo 18. gelima wal trawi uel feni. Mimo pewnych odchyleń mikrostrukturę wokabularza można zatem zdefiniować jako „wyraz(y) łaciński(e) - polski(e) odpowiednik(i)”. Jego makrostruktura jest natomiast bardziej skomplikowana, a przed jej zbadaniem konieczne jest przyjrzenie się materiałowi zawartemu w wokabularzu oraz jego możliwym źródłom.

\subsubsection{Stan badań}

Wszyscy trzej wydawcy analizowali pokrótce strukturę wokabularza oraz - przede wszystkim zawarte w nim słownictwo i stosowaną pisownię, traktując zabytek w pierwszej kolejności jako źródło do poznania języka staropolskiego. Stawiali również hipotezy co do autorstwa, źródeł i okoliczności powstania wokabularza, czyniąc przy tym wiele interesujących, choć często pozbawionych systematyczności spostrzeżeń.

Poza analizami, które towarzyszyły wyżej wymienionym wydaniom, oraz nielicznymi artykułami filologicznymi ${ }^{172}$ informacje o wokabularzu w literaturze przedmiotu ograniczają się z reguły do skrótowych, ogólnikowych wzmianek, opartych - jak się wydaje - przede wszystkim na omówieniu S. Urbańczyka. Czasem oprócz przyjętej daty powstania (1424 r.) oraz liczby wyrazów (500-600, zależnie od sposobu liczenia) pojawia się informacja o rodzaju słownictwa, jakie zawiera wokabularz (prawo i administracja, wojskowość i choroby ${ }^{173}$; prawo, życie społeczne, przyroda, kultura materialna ${ }^{174}$; prawo, wojskowość, administracja itp. ${ }^{175}$, życie publiczne i codzienne ${ }^{176}$ ). Zdarza się, że wokabularz określany jest wręcz jako słownik prawniczy ${ }^{177}$.

167 Wokabularz trydencki, s. 15-29.

168 Stowniczek trydencki, wyd. A. Steffen, wyd. 2 popr., Prace Językowe, t. 1, Londyn 1963.

169 S. Urbańczyk, Pokłosie Wokabularza trydenckiego, „Język Polski”, 42, 1962, nr 5, s. 385 n.; tenże, O poprawne odczytanie Wokabularza trydenckiego, „Język Polski”, 44, 1964, nr 5, s. 299-310.

170 Jako hasło przyjmuje się tu ciąg wyrazów łacińskich i polskich odnoszących się do tego samego denotatu. Według numeracji S. Urbańczyka haseł powinno być 510, rozbijał on jednak niekiedy jedno hasło, jeśli pojawiało się w nim więcej odpowiedników polskich (np. 193. densetum gøste uel 194. alio nomine ganscze, 310. Witta zawoy uel 311. podwika in muliere, ale też 242. preco wosni uel podw<ojs $>k i$ ), natomiast wiele synonimów łacińskich włączał przeważnie do jednego hasła (np. 148. Mansus laneus lan, 360. Manes penates vbosze, ale też 361. tartarus 362. Auernus 363. baratrum, wszystkie trzy objaśnione łącznie jako infernus). Mimo tych niekonsekwencji, aby umożliwić bezpośrednie odniesienie do edycji źródła, w niniejszej pracy stosowana jest numeracja S. Urbańczyka, jednak przy obliczaniu liczby haseł w celach statystycznych stosowane jest kryterium jednego denotatu, tj. np. hasła 361-363 są traktowane jako jedno.

${ }^{171} \mathrm{~W}$ artykule uproszczono transliterację S. Urbańczyka, rezygnując z oznaczania skrótów, korekt i przekreśleń. Zachowano jedynie oznaczenie liter dodanych przez wydawcę (nawias trójkątny).

172 A. Steffen, Biga Stowniczka trydenckiego, „Język Polski”, 45, 1965, nr 4, s. 239-241; A. Bańkowski, Wyrazy trudne w Wokabularzu trydenckim, „Prace Filologiczne”, 36, 1991, s. 245-253. Słownictwo z wokabularza jest wykorzystywane $\mathrm{w}$ artykułach nt. leksyki średniowiecznej; np. K. Bracha, Uboże w świecie zmarlych, w: Dynamika przemian społecznych i religijnych $w$ średniowieczu, red. T. Grabarczyk, T. Nowak, Warszawa 2011, s. 49-70.

173 S. Urbańczyk, Stowniki, s. 9.

174 T. Michałowska, Średniowiecze, Warszawa 1995, s. 331.

175 P. Żmigrodzki, Wprowadzenie do leksykografii polskiej, s. 126.

176 T. Michałowska, Literatura polskiego średniowiecza, s. 884.

177 I. Sułkowska-Kurasiowa, Dokumenty królewskie, s. 91; M. Leńczuk, Zapisy polskie, s. 110. 


\subsubsection{Material leksykograficzny}

Zamieszczona poniżej tabela A prezentuje podział słownictwa zawartego w wokabularzu trydenckim na dziedziny tematyczne. Jest on częściowo inspirowany strukturą semantyczną zastosowaną w Słowniku pojęciowym języka staropolskiego, został jednak dostosowany do materiału zawartego w wokabularzu trydenckim. Dziedziny zostały nakreślone w taki sposób, by pomieściły ten materiał w sposób jak najpełniejszy. Jednocześnie zrezygnowano z uszczegóławiania niektórych dziedzin, aby zapobiec ich nadmiernemu rozdrobnieniu, które utrudniłoby wyciągnięcie ogólnych wniosków o treści słownika. Sześć haseł, które albo mają niepewne znaczenie, albo też wymagałyby utworzenia dziedziny obejmującej tylko jeden przykład, włączono do kategorii ,inne”. Czasami, ze względu na wieloznaczność wyrazów, niepewne odczytania, możliwe błędy kopisty oraz bardzo ograniczony kontekst, ustalenie dokładnego denotatu hasła było utrudnione nawet przy pomocy Słownika staropolskiego ${ }^{178}$ i słowników łaciny średniowiecznej; w kilku przypadkach pomocne okazały się inne średniowieczne słowniki.

Ogromna większość haseł poświęcona jest rzeczownikom, i to rzeczownikom konkretnym i pospolitym; tylko cztery hasła (296-297. presepe preneste sunt propria nomina ciuitatem, 364. Cyclas est [...] proprium nomen insule in mari, 397. ulixes proprium nomen) dotyczą nazw własnych. Haseł czasownikowych jest zaledwie 18, tyle samo co przymiotnikowych. Występuje również jedno hasło przysłówkowe (246. licitum phas - podobno).

Tabela A. Liczebność dziedzin tematycznych w wokabularzu trydenckim ${ }^{179}$

\begin{tabular}{|c|c|c|}
\hline $\begin{array}{l}\text { Dziedzina } \\
\text { tematyczna }\end{array}$ & $\begin{array}{l}\text { Liczba } \\
\text { hasel }\end{array}$ & $\begin{array}{c}\text { Numery hasel } \\
\text { (według numeracji S. Urbańczyka) }\end{array}$ \\
\hline I. Przyroda nieożywiona i zjawiska naturalne & 31 & \\
\hline I.1. Niebo i zjawiska atmosferyczne & 7 & $74,92,209,257,340,353,355$ \\
\hline I.2. Kierunki geograficzne & 2 & 232,233 \\
\hline I.3. Ziemia i woda & 16 & $\begin{array}{l}27,56,57,80,145,161,162,265,334,335,365,366 \\
416,423,426,466\end{array}$ \\
\hline I.4. Inne zjawiska naturalne & 6 & $65,126,158(?), 159,338,339$ \\
\hline II. Rośliny & 36 & \\
\hline II.1. Części roślin & 10 & $55,104,105,107,184,205,269,384,413,442$ \\
\hline II.2. Zgrupowania roślinności i inne terminy ogólne & 6 & $58,59-60,193-194,195,445,446$ \\
\hline II.3. Rośliny uprawne & 14 & $\begin{array}{l}69,70,104,105,107,184,205,248,269,287,288 \\
289,408,462\end{array}$ \\
\hline II.4. Rośliny dzikie rodzime i grzyby & 9 & $155,160,187,189,293,301,317,393,436$ \\
\hline II.5. Rośliny egzotyczne & 3 & $383,384,392$ \\
\hline III. Zwierzęta & 65 & \\
\hline III.1. Części ciała zwierząt & 4 & $103,273,368,375$ \\
\hline
\end{tabular}

178 Por. D. Masłej, Stownik a tekst. Problem znaczenia odpowiedników leksykalnych w staropolskich przekladach Psalmu 50, w: Jak badać teksty staropolskie, s. 103: „Gdy jednak zaczyna się pracę na tekście, niejednokrotnie trzeba zmierzyć się z problemem nieadekwatności definicji z Sstp., wyznaczanych na podstawie całego zachowanego materiału średniowiecznej polszczyzny, często także na podstawie źródeł łacińskich, do znaczeń wyznaczanych kontekstowo w pracy na jednym tekście”; M. Leńczuk, Polskie glosy, s. 97: „Większość analiz semantycznych opiera się na ustaleniach współcześnie redagowanych słowników historycznych i etymologicznych, których twórcy nie zawsze byli w stanie uchwycić intencje pisarzy żyjących w określonych realiach XV wieku".

179 Za jedno hasło przyjmuje się ciąg wyrazów odnoszących się do jednego denotatu. Hasła, które występują w wokabularzu kilkakrotnie, są liczone za każdym razem. Hasła przyporządkowane do kilku podkategorii są liczone tylko raz, w ramach jednej kategorii nadrzędnej. Znakiem zapytania oznaczono hasła o niepewnym znaczeniu. Hasła zapisane z łącznikiem liczone są jako jedno. Gwiazdką oznaczono hasła, które oznaczone są jako jedno w wydaniu S. Urbańczyka, obejmują jednak dwa denotaty i w związku z tym tutaj liczone są podwójnie. 


\begin{tabular}{|c|c|c|}
\hline $\begin{array}{l}\text { Dziedzina } \\
\text { tematyczna }\end{array}$ & $\begin{array}{c}\text { Liczba } \\
\text { hasel }\end{array}$ & $\begin{array}{c}\text { Numery hasel } \\
\text { (według numeracji S. Urbańczyka) }\end{array}$ \\
\hline III.2. Legowiska i domy zwierząt & 3 & $301,321,400$ \\
\hline III.3. Zwierzęta udomowione (oprócz koni) & 6 & $37,42,93,94,102,164$ \\
\hline III.4. Hodowla zwierząt (oprócz koni) & 6 & $82,321,349,350,351,409$ \\
\hline III.5. Konie & 5 & $39,40,41,44,47$ \\
\hline III.6. Hodowla koni & 4 & $2,81,199,506$ \\
\hline III.7. Rząd koński & 10 & $38,63,169,170,171,172,173,174,175,320$ \\
\hline III.8. Zwierzęta dzikie & 23 & \\
\hline III.8.1. Zwierzęta czworonożne & 5 & $68,87,299,300,303$ \\
\hline III.8.2. Ptaki & 8 & $131,163,165,188,231,315,398,429$ \\
\hline III.8.3. Inne & 10 & $13,166,207,251,358(?), 359(?), 391,430,469,470$ \\
\hline III.9. Zwierzęta fantastyczne & 2 & 252,394 \\
\hline III.10. Polowanie i chwytanie & 3 & $117,123,124$ \\
\hline IV. Ciało ludzkie & 41 & \\
\hline IV.1. Części ciała ludzkiego (zob. też. III.1) & 34 & $\begin{array}{l}3,15,16,25,28 *, 29,33,96,97,120,139,206,274, \\
275,276,277(?), 278,279,280,281,282,283,284,285 \text {, } \\
291,312,348,352,367,370,376,435,456\end{array}$ \\
\hline IV.2. Choroby, zranienia i medycyna & 7 & $14,130,204,219,226,415,471$ \\
\hline V. Czynności & 18 & $\begin{array}{l}43,140,156,157,203,238,261,262,263,292,374, \\
380,382,421,422,424,465\end{array}$ \\
\hline VI. Cechy i i właściwości fizyczne & 18 & $\begin{array}{l}\text { 4, 167, 168, 196, 197(?), 200, 208, 247, 326, 327, 369, } \\
371-372,373,379,448,449,453,454\end{array}$ \\
\hline VII. Związki międzyludzkie & 29 & \\
\hline VII.1. Życie w rodzinie & 27 & \\
\hline VII.1.1. Relacje pokrewieństwa i powinowactwa & 10 & $108,109,190,250,485,486,487,488,489,490$ \\
\hline VII.1.2. Inne terminy zwiazane $z$ rodzina & 17 & $\begin{array}{l}5,6,66,67,79,133,135,136,140,236,237,317-318, \\
411,413,467,481,483\end{array}$ \\
\hline VII.2. Inne związki międzyludzkie & 2 & 402,403 \\
\hline VIII. Życie codzienne i kultura materialna & 102 & \\
\hline VIII.1. Narzędzia i przyrządy & 20 & $\begin{array}{l}2,123,124,125,137,138,202,229,286,304(?)^{180}, 319 \text {, } \\
344,443,463,493,494,503,506,507\end{array}$ \\
\hline VIII.2. Dom i budownictwo & 14 & $\begin{array}{l}1,75,76,77,122,234,268,308,324,491,492,495, \\
497,500\end{array}$ \\
\hline VIII.3. Meble i wyposażenie & 13 & $\begin{array}{l}48,294,295,328,329,330,331,332,333,417,418 \text {, } \\
419,420\end{array}$ \\
\hline VIII.4. Naczynia i pojemniki & 15 & $\begin{array}{l}34,35,37,111,112,134,306,307(?), 318,356,431 \text {, } \\
501,502,504,505,508\end{array}$ \\
\hline VIII.5. Ogrzewanie i oświetlenie & 9 & $290,337,425,493,494,495,496,500,503$ \\
\hline VIII.6. Jedzenie & 17 & $\begin{array}{l}69,70,132,224,288,289,292,293,300,317,345,349 \text {, } \\
399,408,437,474,508\end{array}$ \\
\hline VIII.7. Ubrania & 20 & $\begin{array}{l}53,142,143,186,192,211,212,213,214,215,216, \\
310-311,313-314,384,382,385,386,434,447,460\end{array}$ \\
\hline IX. Uczucia & 7 & $220,221,261,410,421,455,459$ \\
\hline X. Cechy charakteru i sposób postępowania & 10 & $198,201,225,254,255,404,405,438,450,451$ \\
\hline
\end{tabular}

180 Strumen krantan - brak pewności co do znaczenia hasła; S. Urbańczyk proponował „część warsztatu tkackiego”; A. Bańkowski poprawiał na „stramen - kętnar” i rozumiał jako ,podkład” (np. pod beczkę), jednak według Słownika polszczyzny XVI wieku „kętnar” ma postać grubej drewnianej belki, natomiast łac. „stramen” to „podściółka ze słomy”. 


\begin{tabular}{|c|c|c|}
\hline $\begin{array}{c}\text { Dziedzina } \\
\text { tematyczna }\end{array}$ & $\begin{array}{l}\text { Liczba } \\
\text { hasel }\end{array}$ & $\begin{array}{c}\text { Numery hasel } \\
\text { (według numeracji S. Urbańczyka) }\end{array}$ \\
\hline XI. Śmierć i zniszczenie & 5 & $130,271,342,346,347$ \\
\hline XII. Religia & 10 & $1^{181}, 129,210,270,272,336,385,405,412,436$ \\
\hline XIII. Czary, wróżby i sfera nadprzyrodzona & 8 & $71,85,86,144,230,249,360,361-363$ \\
\hline XIV. Gospodarka & 116 & \\
\hline XIV.1. Rolnictwo & 68 & \\
\hline XIV.1.1. Uprawa roślin & 26 & $\begin{array}{l}7^{*}, 18,62,69,70,104,105,106,107,137,138,184,205 \\
248,258,262,269,287,288,289,320,373,408,462,507\end{array}$ \\
\hline XIV.1.2. Przeksztatcenia krajobrazu & 4 & $36,259,377,427$ \\
\hline XIV.1.3. Hodowla zwierząt (w tym koni) & 32 & $\begin{array}{l}2,37,38,39,40,41,42,43,44,47,63,81,82,93,94, \\
102,103,164,169,170,171,172,173,174,175,199, \\
320,321,351,368,409,506\end{array}$ \\
\hline XIV.1.4. Inne & 6 & $200,369,371-372,373,447,472$ \\
\hline XIV.2. Wydobycie, rzemiosło, przetwórstwo & 16 & $\begin{array}{l}61,126,127,162,202,203,228,264,265,304(?)^{182} \text {, } \\
305,316,461,472,498,499\end{array}$ \\
\hline XIV.3. Handel i obrót pieniężny & 8 & $72,73,128,191,326,357,401,441$ \\
\hline XIV.4. Zawody i zajęcia & 24 & $\begin{array}{l}30,45,46,49,51,52,54,81,82,85,86,99,121,154, \\
228,230,235,236,237,256,316,387,290,482\end{array}$ \\
\hline XV. Praca intelektualna, pismo, literatura & 6 & $30,256,309,341^{183}, 396,397$ \\
\hline XVI. Rozrywka & 7 & $51,52,152,154,388,389,467$ \\
\hline XVII. Transport, lokomocja, podróż & 18 & $\begin{array}{l}26,38,48,64,98(?)^{184}, 113,114,115,116,150,151, \\
152,239,240,378,458,509,510(?)\end{array}$ \\
\hline XVIII. Życie publiczne & 62 & \\
\hline $\begin{array}{l}\text { XVIII.1. Nazwy urzędów/godności (z wyłączeniem } \\
\text { wojskowych - zob. XIX.1) }\end{array}$ & 19 & $\begin{array}{l}8,9,12,17,19,20,54,81,88,89,241,242,243,244, \\
476,477,478,479,480\end{array}$ \\
\hline XVIII.2. Insygnia władzy/godności/urzędu & 5 & $385,386,417,418,419$ \\
\hline XVIII.3. Zwroty grzecznościowe & 5 & $24,245,255,402,405$ \\
\hline XVIII.4. Terminy związane z procesem sądowym & 17 & $\begin{array}{l}17,23,88,89,90,81,241,242,253,298,343,419,457, \\
465,468,475,480\end{array}$ \\
\hline XVIII.5. Opłaty i daniny & 6 & $19,20,21,22,152,350$ \\
\hline XVIII.6. Miary i obliczenia & 10 & $146,147,148,149,227,322,323,344,377,464$ \\
\hline XVIII.7. Świat „poza prawem” i przestępczość & 10 & $31,32,49,50,66-67,406,414,439,440,452$ \\
\hline XIX. Walka i uzbrojenie & 32 & \\
\hline XIX.1. Stanowiska, godności i funkcje & 9 & $10,11,46,83,84,99,235,390,482$ \\
\hline XIX.2. Uzbrojenie & 19 & $\begin{array}{l}41,95,100,101,118-119,176,177,178,179,180,181, \\
182,183,185,395,428,432,433,434\end{array}$ \\
\hline XIX.3. Fortyfikacje & 2 & 266,267 \\
\hline XIX.4. Walka & 2 & 140,457 \\
\hline XX. Nazwy własne & 4 & $296,297,364,397$ \\
\hline XXI. Inne & 6 & $78,110,222,246,354(?), 484(?)$ \\
\hline
\end{tabular}

${ }^{181}$ Cenofaya chlodnicza - jeśli przyjąć znaczenie scenopegia związane ze Świętem Szałasów.

182 Zob. przyp. 180.

183 Momentum [a. Monimentum] precium ab equo - por. Owidiusz, Amores, Elegia X, 27-28: „non equa munus equum, non taurum vacca poposcit, / non aries placitam munere captat ovem". Komentarz z wydania z 1689 r., Pub. Ovidii Nasonis Opera, t. 1, Lugduni 1689, s. 276, brzmi: „Equa non petit pretium ab equo, non vacca a tauro”.

184 Vector czolnek - brak pewności co do znaczenia hasła, „vector” to „przewoźnik” lub „pasażer”, „,czołnek” według Słownika staropolskiego może oznaczać „łódkę” albo „czółenko tkackie”. 
Przegląd dziedzin, do których należy słownictwo wokabularza, pozwala stwierdzić, że te wysuwane często na pierwszy plan w literaturze, przede wszystkim prawo i administracja, nie są bynajmniej dominujące. $Z$ pewnością przesadą jest określanie wokabularza jako słowniczka prawniczego. Kategoria „życie publiczne” (XVIII) obejmuje wprawdzie aż 62 hasła, jednak oprócz nazw godności i urzędów administracyjnych oraz terminologii typowo prawniczej zaliczono do niej również zwroty grzecznościowe, miary oraz świat „poza prawem”. Również wspominana nieraz w literaturze dziedzina wojskowości (XIX), choć stosunkowo obszerna, nie dominuje pod względem liczebności wśród innych kategorii; uwagę badaczy zwróciła być może swoją względną zwartością, jako że hasła z tej dziedziny często występują w wokabularzu obok siebie w zgrupowaniach $(10-11,83-84,100-101$, 118-119, dłuższa seria 176-185, 266-267, 432-434). Ciekawe, że podobnego nacisku nie położono na podobną pod względem liczebności dziedzinę „części ciała ludzkiego” (IV.1), której wyrazy również występują w seriach (15-16; 28-29; większa grupa 273-285, obejmująca głównie części głowy i nóg; 367-370, 375-376).

Okazuje się zatem, że „prawo” i ,wojskowość” nie są bynajmniej kategoriami reprezentatywnymi dla wokabularza. Wręcz przeciwnie, wyróżniają się spośród reszty zawartości, która należy w dużej części do mniej przemawiającej do wyobraźni dziedziny życia codziennego i kultury materialnej (VIII), obejmując nazwy narzędzi, wyposażenia, naczyń, ubrań, jedzenia, części domu itp. Wyróżnić można wyrazy związane z ogniem i paleniskiem (VIII.5) oraz całą serię haseł odnoszących się do łóżka (328-333). Co ciekawe, wśród ubrań przeważają przedmioty drobne (np. nazwy zaponek, 214-216), często służące głównie ozdobie - np. 142. pretexta tkanicza (ozdobny pas np. do bramowania szat), 186. strophium opasane lub 213. Supara powesitki (ozdoba rękawa). Aż 8 z 20 haseł dotyczących ubrań dotyczy nakryć głowy, często kobiecych: 143. Aurile patlik, 192. Tyara yalmunicza, 211. reticulum Cepecz, 310-311. Witta zawoy uel podwika in muliere, 313-314. Redimiculum sloyerz uel Cranecz, 381. Sertum venecz oraz 385. Infula dicitur corona episcopi i 386. dyadema corona regis. Po tych ostatnich przykładach widać, że strój może być również symbolem godności.

Uwagę zwraca także duża liczba haseł związanych z rolnictwem, krajobrazem wiejskim oraz przyrodą ożywioną i nieożywioną (I-III, XIV.1). W kategorii roślin (II) dużo jest terminów ogólnych, takich jak „kora” (55) czy ,gaj” (59-60). Występują jednak również odniesienia do konkretnych gatunków lub typów roślinności, przede wszystkim roślin rosnących dziko, ale też uprawnych (m.in. zbóż, pojawiających się jako kłosy i plewy [104-107], kapusty [70 i 408] oraz winorośli [287-289]) i egzotycznych (reprezentowanych przez wawrzyn [383-394] i bawełnę [392]).

Różnorodna jest także kategoria zwierząt (III), gdzie obok stworzeń fantastycznych (takich jak smok [252] albo Spinx [394]) i egzotycznych (gamaleon [358] czy jedwabnik [391]) pojawiają się rodzime dzikie (np. cietrzew [163], wydra [303], wąż [251] czy jesiotr [469], a także 420. buffo solw) i udomowione (np. kot [94], baran [42], byk [102]). Na szczególną uwagę w tej ostatniej kategorii zasługuje koń (III.5-III.7), który może nosić różne nazwy w zależności od swojej funkcji (jak pociągowy 39. Veredus wosnik lub bojowy 41. hastiber horzs) i z którym wiąże się obfita terminologia dotycząca uprzęży. Czasem zwierzęta pojawiają się tylko częściowo (np. jako zwisające podgardle [103], wymię [368] albo grzywa [273 i 375]), czasem zaś na pierwszy plan wysuwa się ich siedziba (barłóg [301 i 400] lub gołębnik [321]). Istotną częścią terminologii związanej ze światem zwierząt jest z pewnością ta opisująca działania podejmowane wobec nich przez człowieka: może on na nie polować (przy pomocy sideł [123-124] lub sieci [117]), ale może je również hodować (a wtedy potrzebny jest pasterz [82], pastwisko [84], żłób [409] i zgrzebła [201 i 506]) oraz wykorzystywać do pracy (w tym mieści się wspomniana już terminologia dotycząca uprzęży, która musiała szczególnie zainteresować jednego z użytkowników wokabularza, ponieważ na marginesie serii haseł 169-175 oznaczył ją manikulą).

Przyroda nieożywiona (I) obejmuje przede wszystkim elementy krajobrazu (np. pagórki [27], skały [80 i 426], jeziora [335] i bagna [161 i 334]), a także różnorakie zjawiska naturalne, również atmosferyczne (np. grom [340] czy 355. Aurora zaza [tj. zorza]). Do tej dziedziny zalicza się również tajemnicze hasło 466. frecella gellutrix gruda, zawierające nieznane skądinąd wyrazy łacińskie; należy jednak chyba rozumieć je jako „zmrożoną grudę ziemi”. 
Znacznie skromniej (XIV.2) wypada wydobycie (metali [127, 162, 264-265) i soli [472]), rzemiosło (reprezentowane przez tkactwo [202-203, 304?-305], zduństwo [228] i bednarstwo [316]) oraz przetwórstwo (w zasadzie ograniczone do produkcji piwa [61, 498-499]). Określeń związanych z handlem i gospodarką pieniężną jest zaledwie garstka (XIV.3). Także kategoria religii (XII) nie imponuje rozmiarami i obejmuje terminy związane z zewnętrznymi elementami kultu (np. kruchta [270], krzyżmo [336] czy palma wielkanocna [436]), jak również całkowicie - wydawałoby się - podstawowe hasło 129. Eukaristia corpus christi. Dwa hasła (272 i 412) dotyczą odstępstw od ortodoksji; interesujące jest pierwsze hasło wokabularza Cenofaya chlodnicza, które można rozumieć jako odniesienie do żydowskiego Święta Szałasów.

Kategoria związków międzyludzkich, dotycząca przede wszystkim życia w rodzinie (VII), nie należy do najliczniejszych, ale jest dobrze widoczna dzięki zgrupowaniu w serii haseł 481-490. Obok terminów dotyczących stricte określenia pokrewieństwa występują też funkcje związane $\mathrm{z}$ małżeństwem i narodzinami dzieci (jak dziewosłąb [79 i 483] czy mamka [236]), a także nazwy oznaczające ród $(133,217-218,411,413)$.

Słownik zawiera ponadto wyrazy m.in. z dziedzin cech i właściwości fizycznych (VI), uczuć (IX), czarów (XIII), rozrywki (XVI) czy lokomocji i transportu, zarówno wodnego, jak i lądowego (XVII). Całościowe spojrzenie na materiał leksykograficzny wokabularza pozwala wysnuć dwa wnioski. Po pierwsze, jest to z całą pewnością słownik wielodziedzinowy, o bardzo różnorodnej zawartości, w której trudno wyróżnić jakąs dominantę. Gdyby jednak próbować wskazać obszar, który wydaje się najważniejszy dla twórcy wokabularza, to byłoby to życie codzienne, i to raczej w wydaniu wiejskim i rolniczym. Po drugie, nie jest to słownik terminologiczny: zawarte w nim słownictwo, choć nieraz bardzo szczegółowe, trudno nazwać specjalistycznym czy fachowym, może z wyjątkiem ok. 30 wyrazów związanych ściśle z prawem i administracją.

\subsection{3. Źródla i geneza wokabularza}

Ponieważ niektóre hasła występują w wokabularzu dwukrotnie, $\mathrm{i}$ to $\mathrm{w}$ różnej pisowni ${ }^{185}$, już E. Winkler uważał, że jego twórca spisywał je z co najmniej dwóch źródeł, pochodzących z różnych okresów ${ }^{186}$. Cytując go, S. Urbańczyk pominął kwalifikator „co najmniej”"187, zauważył również, że wokabularz musi być kopią starszego rękopisu, na co wskazują błędy (np. 354. conticinium prziswi zamiast „pirwospy”). Kopistą miał być jego zdaniem ,jakiś ksiądz, blisko związany z [Aleksandrem - B.K.], z dworem królewskim i z uniwersytetem, może któryś z tych, co się z biskupem wybrali w daleką drogę do Trydentu"188.

Również A. Steffen stwierdził, że wokabularz jest odpisem (jak zresztą wszystko w kodeksie), i zwrócił uwagę m.in. na niestaranności pisowni oraz błędne przepisanie wyrazu czotka (ciotka) jako kotka (250). Był przy tym zdania, że cechy pisowni wskazują na to, iż oryginał wokabularza wyszedł w całości spod ręki anonimowego autora w pierwszej połowie XIV w. (a zatem 70-100 lat przed kopią, która przetrwała w kodeksie trydenckim). Ten anonimowy autor miał ułożyć wokabularz samodzielnie, wykazując się pomysłowością, zamiłowaniem do słownictwa i dobrym wykształceniem ${ }^{189}$.

Odrzucić należy hipotezę Andrzeja Bańkowskiego, wedle której wokabularz został spisany już we Włoszech, i to przez Włocha, któremu treść podyktował Polak z otoczenia Aleksandra, co miałoby

${ }^{185}$ Haseł powtarzających się zarówno w części łacińskiej, jak i polskiej jest 14. Są to: 2. Strigillis grzeblo / 506. strigillis greblo, 9. Senascallus marsalek / 478. Senascallus marsalek, 58. Virgultum zapusta / 195. Virgultum zapusta, 79. procus dewoslab / 483. prochus dzewosløb, 80. Saxum scala / 426. petra Saxum scala, 95. pilum strala / 185. pilum strala, 107. Spica klos / 184. Spica clossz, 120. grabla [sic] pzedzal / 348. Glabra przedal, 136. Virago masatka / 481. Virago møsrzatka, 149. stadium stage / 322. Stadium stage, 219. Cikatrix sram uel rana / 415. Cycastrix sram, 247. velox celer røczy / 448. celer røczy, 273. Coma grrzywa / 375. Coma grziwa, 301. Cubile barlog / 400. Cubile barlog.

186 Il più antico dizionario latino-polacco, s. 99.

187 Wokabularz trydencki, s. 17.

188 Tamże, s. 16.

189 Stowniczek trydencki, 1960-1961, s. 232, 237. 
tłumaczyć błędy w pisowni polskiej i osobliwości łaciny ${ }^{190}$. Pomijając już karkołomność takiego przedsięwzięcia, przypomnieć trzeba, że niemal cały kodeks spisano jedną ręką, a związek pozostałych zawartych w nim materiałów z Polską jest niezaprzeczalny. Zresztą i w samym wokabularzu występują terminy typowe dla kontekstu polskiego, np. 253. banitum judicium gayni søndz.

A. Bańkowski dostrzegał również w wokabularzu „liczne dialektyzmy staromazowieckie"191, w czym zgadzał się z S. Urbańczykiem, który także - choć z większą ostrożnością - wysunął tezę, że pisarz pochodził z Polski północnej. Na uzasadnienie tego twierdzenia podał jednak tylko kilka przykładów, a ważniejszym argumentem niż charakterystyka polszczyzny wokabularza wydaje się mazowieckie pochodzenie księcia Aleksandra, jako że „obecność jakiegoś księdza Mazura w otoczeniu potomka książąt płockich byłaby jak najbardziej naturalna" ${ }^{192}$. Należy jednak pamiętać, że pisarz wokabularza najprawdopodobniej nie był jego twórcą, lecz kopiował jakiś wcześniejszy tekst (lub teksty, jeśli dopiero on dokonał ich kompilacji), o nieznanym czasie i miejscu powstania. Można powątpiewać, czy pisownia w wokabularzu trydenckim pozwala wnioskować o wymowie pisarza, a w konsekwencji o jego przynależności regionalnej ${ }^{193}$. Gdyby jednak podjąć taką próbę, to cechy poszczególnych dialektów wskazane przez Marię Bargieł ${ }^{194}$ pozwalają równie dobrze na identyfikację z dialektem mazowieckim, jak i małopolskim. Przypomnijmy, że reszta kodeksu - listy i dokumenty pochodzące w dużej części z kancelarii królewskiej oraz dwa czeskie kazania - wskazywałyby raczej na Polskę południową.

Wydaje się, że osoba pisarza, tak samo jak twórcy wokabularza, musi pozostać nieuchwytna. Bardziej owocna może okazać się próba ustalenia źródeł zawartego w wokabularzu słownictwa. W pierwszej kolejności należy się zastanowić, czy może ono w części pochodzić z pozostałej części kodeksu. 86 wyrazów łacińskich z wokabularza pojawia się w innych wpisach zawartych w kodeksie, a przeważająca ich część (26) należy do kategorii ,życie publiczne”, co nie dziwi, zważywszy na w większości formularzową treść kodeksu. Również wyrazy z innych kategorii występują w kontekstach prawniczych - tak jest np. w przypadku dampnum i periculum, jak również sanus, które pojawia się najczęściej we frazach typu sanus mente. Wyrazy deuotus, famosus, consors, prouidus i circumspectus występują m.in. w zwrotach adresatywnych. Jednocześnie należy zauważyć, że mimo stosunkowo dużej grupy wyrazów dotyczących życia publicznego, ani wszystkie hasła z tej dziedziny, które występują w wokabularzu, nie pojawiają się w reszcie kodeksu (powtarza się około połowa haseł: 10 z 19 nazw urzędów i godności oraz 8 z 17 terminów związanych z procesem sądowym), ani też wszystkie wyrazy z tej dziedziny w kodeksie nie mają swoich objaśnionych odpowiedników w wokabularzu (swoich haseł nie mają np. subiudicus, procurator czy burgravius). Porządek haseł nie odzwierciedla też kolejności, w jakiej wyrazy występują w pozostałej części kodeksu; jedyne wyjątki to grupa 169. antela popersini, 170. postela pochwy, 175. selipendia czebenczy, jako że wszystkie trzy wyrazy lacińskie pojawiają się we wpisie nr 153, dotyczącym zakupu siodła, oraz być może para 176. lorica pancer i 183. pixis misile puska, która ma swój odpowiednik we fragmencie wpisu $\mathrm{nr} 42$,ex parte vestri unam loricam cum casside et pixidibus nobis obtulit pro munere" ${ }^{195}$. Warto zauważyć, że wyraz cassis, który również występuje w tym fragmencie, w wokabularzu pojawia się w całkiem innym miejscu, tj. w haśle 118 . $\mathrm{Z}$ tego względu wydaje się mało prawdopodobne, by wokabularz powstał - choćby częściowo - na podstawie formularzowej części kodeksu.

Źródłem mniej wątpliwym jest Graecismus Eberharda z Béthune - bardzo popularny, znany również w Polsce ${ }^{196}$, wierszowany traktat gramatyczny wykorzystywany w nauczaniu łaciny. Zbieżności między

190 A. Bańkowski, Wyrazy trudne, s. 245.

191 Tamże.

192 Wokabularz trydencki, s. 19.

${ }^{193}$ Por. M. Trawińska, Cechy dialektalne wielkopolskich rot sądowych w świetle badań nad rękopisem poznańskiej księgi ziemskiej, „Prace Filologiczne”, 56, 2009, s. 357: „wielu zagadnień językowych nie można rozpatrywać w oderwaniu od grafii, która jest bardzo skomplikowana i często wręcz uniemożliwia ustalenie relacji litera - głoska".

194 M. Bargieł, Cechy dialektyczne polskich zabytków rękopiśmiennych pierwszej połowy XVI wieku, Prace Językoznawcze Komitetu Językoznawstwa PAN, t. 55, Wrocław 1969, s. 154 n.

195 „Liber disparata antiqua continens”, s. 23.

196 T. Michałowska, Średniowieczna teoria literatury w Polsce. Rekonesans, Toruń 2016, s. 50. 
wokabularzem trydenckim a rozdziałami IX-XII tego traktatu przedstawiono w tabeli 1 (zob. Aneks). Graecismus (nazwany tak od rozdz. VIII, w którym omówione są wyrazy pochodzenia greckiego) nie jest ściśle rzecz biorąc słownikiem. Jego rozdziały poświęcone słownictwu zawierają wprawdzie objaśnienia, czy to przez synonimię, czy to definicję (expositio), czy to przez wskazanie etymologii ${ }^{197}$, czasem jednak ograniczają się do zestawienia dwóch lub więcej słów paronimicznych (podobnych brzmieniowo $)^{198}$ albo pochodzących z jednej dziedziny ${ }^{199}$, po to, by zasygnalizować różnicę w znaczeniu. W wokabularzu trydenckim takie zestawienia bywają przytaczane nieraz dosłownie (najjaskrawszy przykład to 28 . In dorso gibus / In pectore giber ${ }^{200}$ ), natomiast w innych przypadkach jego twórca wynotowywał tylko wyraz z traktatu i dopisywał do niego polski odpowiednik.

Konstruowanie wokabularza na bazie Graecismusa jest najbardziej widoczne na początku, gdzie najwięcej jest haseł następujących po sobie w kolejności podobnej do tej, w jakiej występują w dziele Eberharda. Zapożyczenia $\mathrm{z}$ traktatu przewijają się jednak w zasadzie do samego końca wokabularza, aż do 441. fenus dux usura, które to hasło staje się jaśniejsze dzięki frazie duplex usura u Eberharda. Innym zapisem zyskującym na przejrzystości jest 394. Spinx monstrum marinum, które musi być zniekształconym w toku przepisywania pistrix. W tabeli podano 145 miejsc wspólnych, ale w rzeczywistości ich liczba jest zapewne bliższa 100. Niektóre hasła w wokabularzu powtarzają się, a chociaż również w Graecismusie zdarzają się powtórki, bardziej prawdopodobne jest, że „dublety” przywędrowały do wokabularza skądinąd. Również w przypadku pojedynczych haseł możliwe jest, że dany wyraz przyszedł do wokabularza z innego źródła. Tam jednak, gdzie sąsiadują ze sobą hasła, które również w Graecismusie występują blisko siebie, zapożyczenie nie ulega wątpliwości. Dobrym przykładem są hasła 437 i 438, czyli Condimentum vcrasene i sal significat sapientiam 2-modo, których odpowiednikiem w Graecismusie są wersy 17-18 rozdz. XII: „Sal neutri generis condimentum notat oris / Hic sal si dicas id quod sapientia signat". Analogicznie jest z parą 266-267: Menia czena (które nastręczało niemałych trudności wydawcom) i propugnaculum colowrotni, co odpowiada wersom 69-70 w rozdz. XI: „Materiam gracilem murorum menia dicas / Ast intersticia sunt propugnacula dicta”.

Jeden z „dubletów” w wokabularzu można uzasadnić właśnie zniekształconym nawiązaniem do Graecismusa. Chodzi tu o hasło 184. Spica clossz, przerywające ciągnącą się od nr. 176 serię wyrazów związanych z uzbrojeniem i sąsiadujące z 185. pilum $s t<r>$ ala. Ze względu na ten kontekst A. Bańkowski kwestionował odczytanie S. Urbańczyka i postulował, by przyjąć znaczenie „grot, ostrze strzały”. Twierdził też, że wyraz polski jest słabo czytelny i należałoby widzieć w nim „ostrsz” lub „ostssz”201. Z tym ostatnim trudno się zgodzić: w rękopisie wyraźnie zapisano „clossz”, jak to odczytał S. Urbańczyk (podobnie zresztą jak A. Steffen, u którego jest „closs”). Porównanie z Graecismusem częściowo potwierdza jednak intuicję A. Bańkowskiego: rozdz. XI zawiera wersety „Dicitur a iactu iaculum; telum quia longum / Missile nomen habet quia mittitur impetuose / Spicla simul pyla generaliter ista vocantur", które były podstawą dla serii 181-185 w wokabularzu trydenckim, poświęconej właśnie nazwom pocisków. Wskutek błędu kopisty spicla (grot strzały) zmieniło się w spica i dopiero po tej pomyłce zostało objaśnione po polsku jako „kłos”. Rodzi to pytania o proces tworzenia wokabularza: wydaje się, że najpierw powstała lista wyrazów łacińskich, do której dopisano później polskie odpowiedniki. Przykład spica clossz wyklucza możliwość, by twórca wokabularza korzystał z glosowanej kopii Graecismusa.

Można również dostrzec pewne podobieństwa między wokabularzem trydenckim a innymi słownikami $\mathrm{z}$ tego okresu. S. Urbańczyk wykluczył pokrewieństwo z granariuszami (Vocabularius Ex quo), dostrzegł natomiast zbieżności ze słownikiem zapisanym na marginesie dzieła Bertolda z Eisenach w rękopisie

\footnotetext{
197 Na przykład Dicitur unguentum quoniam nos ungimur illo - rozdz. XI; cyt. w przyp. 197-199 według inkunabułu Graecismus cum commento z 1487-1488 r., zdygitalizowanego i dostępnego na stronie $<$ https://archive.org/details/OEXV571_P2> [dostep: 23.02.2019].

198 Na przykład Palma manus; palma est arbor; victoria palma - rozdz. X.

199 Na przykład Virgo pudiciciam notat; etatemque puella / Sed tamen improprie pro virgine dico puellam - rozdz. X.

200 Już S. Urbańczyk (Wokabularz trydencki, s. 17) zwrócił uwagę, że fraza ta pojawia się jako przykład u Charles’a du Fresne du Cange.

${ }^{201}$ A. Bańkowski, Wyrazy trudne, s. 250.
} 
BJ nr 228 oraz z dwoma słownikami późniejszymi, z XVI w., w tym ze słownikiem Bartłomieja z Bydgoszczy ${ }^{202}$. Zdaniem Hanny Popowskiej-Taborskiej 250 wyrazów polskich zawartych w wokabularzu trydenckim występuje również w tym ostatnim ${ }^{203}$. Trudno jednak mówić o wpływach bezpośrednich, bardziej prawdopodobne jest korzystanie przez twórców słowników ze wspólnych źródeł ${ }^{204}$.

W charakterze przykładu w pozostałych kolumnach tabeli 1 przedstawiono zbieżności - bardziej lub mniej pewne $-\mathrm{z}$ dwoma słownikami polskimi oraz jednym czeskim, które wybrano ze względu na czas powstania (od końca XIV do połowy XV w.), formę (objętość: kilkaset haseł, dominująca mikrostruktura: wyraz[y] łaciński[e] - odpowiednik[i] polski[e]) oraz dostrzeżone zbieżności z zawartością wokabularza trydenckiego ${ }^{205}$.

Choć S. Urbańczyk negował wpływy czeskie w wokabularzu trydenckim ${ }^{206}$, wykazuje on podobieństwa z tzw. słowniczkiem świętowickim (slovniček svatovitský) z końca XIV w. Znaleziono 84 zbieżności między nimi. Nie jest to wprawdzie wynik imponujący (odpowiada niespełna $17 \%$ haseł wokabularza trydenckiego i nieco ponad 13\% haseł słowniczka świętowickiego), jednak podobieństwa są znamienne i nieraz rzucają nieco światła na niektóre wyrazy w wokabularzu trydenckim: można potraktować np. 277. Cerebellum plecz jako zniekształconą wersję czeskiego 72. Cerebellum leb. Bardziej zrozumiałe stają się również hasła 408. beta odrosly (por. 267. betha hlawatyczye) oraz 304. strumen krantan (por. 620. Stramen Slama). Interesujące jest zwłaszcza hasło w czeskim słowniku 304. penus pywnyczna ssygye, odpowiadające polskiemu 234. penus piwniczna sziga. Słownik staropolski notuje przy haśle „piwniczna szyja" tylko jeden przykład, właśnie z wokabularza trydenckiego, możliwe zatem, że jest to bohemizm.

Obydwa słowniki polskie, z którymi porównano wokabularz trydencki, są od niego późniejsze. Pierwszy z nich to słownik na marginesie traktatu Bertolda z Eisenach w rękopisie BJ 228 III z 1437 r. Ma on porządek alfabetyczny, choć ograniczony do pierwszej litery wyrazu hasłowego. Na końcu, po haśle zeuma ząel, następuje jeszcze 41 haseł ułożonych mniej więcej w porządku rzeczowym (można wyróżnić grupy wyrazów z kategorii odzienia, naczyń, uzbrojenia i części domu), przy czym niektóre dublują się z hasłami z części alfabetycznej (galea helm, magale chalupa). Z ciekawszych zbieżności między tym słownikiem a wokabularzem trydenckim warto wymienić trójkę 178. collis przigorek - 182. callus modzel vel via - 185. callis twarda droga, która odpowiada w wokabularzu trydenckim serii 25. Callus modzel-26. Callis goscinecz - 27. Collis pagorek. Wspomniany powyżej wyraz penus słownik z BJ nr 228 tłumaczy jako przetpywnicze. W sumie można doliczyć się 113 podobieństw między nim a wokabularzem trydenckim, czy to w zakresie polskiej i łacińskiej, czy też tylko łacińskiej części hasła.

Drugi z polskich słowników pochodzi z zaginionego rękopisu Lat.I.F.ch.254, który A. Brückner datował na 1455 r. Tu zbieżności jest tylko 77, ale niektóre z nich są interesujące: np. łacińskie buffo zostaje objaśnione jako zolwy (por. 430. buffo solw w wokabularzu trydenckim i, dla kontrastu, 497. Buffo zaba w słowniczku świętowickim). Hasło 57. campaster polnycza bliskie jest trydenckiemu 447. Campestre polnicza, które S. Urbańczyk tłumaczył jako „ubiór roboczy”, powołując się na słownik jezuity Grzegorza Knapskiego. W zaginionym rękopisie wystąpiło również hasło 471. stripla garleda sucadium

202 Wokabularz trydencki, s. 19

203 H. Popowska-Taborska, Czy Słownik Bartłomieja z Bydgoszczy jest zwykłą kompilacją wcześniejszych zbiorów leksykalnych, „Język Polski”, 52, 1972, nr 3, s. 178.

204 Wokabularz trydencki, s. 19.

$205 \mathrm{Na}$ potrzeby niniejszego artykułu wystarczające było porównanie na podstawie dostępnych edycji źródeł. Słownictwo wokabularza trydenckiego porównano również ze słownikiem Vocabula rethoricalia z rkps. BJ 2503, datowanym na 1428 r., polską zawartością w dwóch kopiach Vocabulariusa Ex quo wydanych przez A. Brücknera (Lat.XVI.Q.ch.32/33 i Lat.XVI.F.ch.12; rękopisy spłonęły w czasie wojny, wyd. w: A. Brückner, Z rękopisów petersburskich) oraz w będącym również kopią Vocabulariusa Ex quo „słowniku Piotra z Uścia” (Archiwum Biblioteki Krakowskiej Kapituły Katedralnej, sygn. KP 224 z 1450 r., wyd. wyrazów polskich w: I. Polkowski, Katalog rękopisów kapitulnych katedry krakowskiej, Kraków 1884, s. 163-164), jednak nie odnaleziono w nich zbieżności z wokabularzem.

206 Wokabularz trydencki, s. 19. Tezę tę, oprócz podobieństw z czeskim słownikiem, podważa również m.in. hasło 457. duellum id est duorum bellum uel wlgariter szadane, które zidentyfikowano jako bohemizm „siadanie”; zob. Słownik pojęciowy języka staropolskiego, <http://spjs.ijp.pan.pl/haslo/index/14926> [dostęp: 23.02.2019]. 
kwaszenyna, mogące stanowić argument za odczytaniem przez S. Urbańczyka hasła 132. Scriffa quasenina, które przysporzyło wydawcom niemałych problemów.

Zbieżności z innymi słownikami nigdy nie przekraczają 20\% słownictwa wokabularza, a podobieństwa dotyczą przede wszystkim wyrazów łacińskich, rzadziej natomiast ich odpowiedników w językach wernakularnych, które zwykle różnią się w zależności od słownika. Odmienna jest także kolejność haseł. O ile między Graecismusem a wokabularzem trydenckim istnieją w tym względzie wyraźne podobieństwa, o tyle w trzech słownikach porządek jest zupełnie inny (w słowniku na marginesie Bertolda w większości alfabetyczny, w zaginionym słowniku wydanym przez A. Brücknera - częściowo alfabetyczny, częściowo rzeczowy, częściowo tekstowy, a w słowniku czeskim bez dokładniejszej analizy trudno określić rodzaj makrostruktury). Warto też zauważyć, że niektóre łacińskie wyrazy hasłowe powtarzają się w trzech lub czterech z pięciu porównywanych źródeł, co wskazuje na istnienie średniowiecznych tradycji leksykograficznych. Niektóre zbieżności mogą być przypadkowe, wiele jednak wynika najprawdopodobniej z korzystania przez twórców słowników ze wspólnych źródeł - czy to gotowych już dzieł leksykograficznych, czy też innych tekstów, np. gramatycznych, takich jak Graecismus.

\subsubsection{Makrostruktura wokabularza}

E. Winkler określał porządek wokabularza jako rzeczowy („per materie”) ${ }^{207}$, z czym nie zgadzał się A. Steffen, mówiąc o bardzo ograniczonym występowaniu zgrupowań tematycznych i częstym rozproszeniu materiału dziedzinowego na kilka serii zapisanych w różnych miejscach. Zwrócił za to większą uwagę na podążanie autora słownika za skojarzeniami wynikającymi z podobieństwa formy wyrazów i pokrewieństwa słowotwórczego ${ }^{208}$. A. Bańkowski wyróżnił natomiast zestawy wyrazów paronimicznych, synonimicznych, pokrewnych słowotwórczo i ,związanych semantycznie z konkretnym tematem realnym" ${ }^{209}$. W rzeczywistości podział ten nie jest zupełnie jasny, bardzo często mamy bowiem do czynienia ze współwystępowaniem relacji onomazjologicznych i semazjologicznych. Zgrupowane wyrazy jednocześnie należą do jednej dziedziny tematycznej, są ze sobą powiązane słowotwórczo i mają na tyle odmienne znaczenie, że można uznać je za paronimy: przykładem hasła 69. olus ger i 70. olera odrosly czy 156. fugio vcekam i 157. fugo gonø (w tym ostatnim przypadku można mówić jeszcze o antonimii).

$\mathrm{W}$ tabeli 2 (zob. Aneks) przedstawiono sposoby uporządkowania haseł w wokabularzu, wyróżniając trzy rodzaje relacji między nimi: onomazjologiczne, czyli tematyczne; paronimiczne, czyli związane z podobieństwem formy wyrazów; etymologiczne, czyli związane z pokrewieństwem słowotwórczym. Wbrew zastrzeżeniom A. Steffena porządek onomazjologiczny wydaje się dominować, choć dłuższych serii haseł przedstawiających w sposób względnie wyczerpujący słownictwo z danej dziedziny jest stosunkowo niewiele. Na tle całego wokabularza wyróżniają się zgrupowania dotyczące koni (7 haseł, 38-48), uprzęży (7 haseł, 169-175), uzbrojenia (9 haseł $\left.{ }^{210}, 176-185\right)$, części ciała (13 haseł, 273-285) i rodziny ( 8 hasel, 481-490). Inne zestawy tematyczne są krótsze, a czasem ta sama kategoria semantyczna powraca kilkakrotnie w odrębnych seriach, jak nazwy urzędów i godności (8-9, 242-244, 476-480). Najczęściej występują zestawienia dwóch lub trzech haseł, które albo należą do tej samej dziedziny tematycznej (np. miary: 322. Stadium stage i 323. Juger wrzecen lub słownictwo związane z transportem wodnym: 150. Remus woslo i 151. Naulum plet), odnoszą się do zjawisk pokrewnych, lecz wyraźnie skontrastowanych (np. 5. pupillus sirota i.e. carens matre i 6. Orphanus carens utroque lub 72. Moneta signum in grosso i 73. Munisma signum in minimo), są bliskoznaczne (np. 346. periculum sguba, 347. dampnum skoda) albo też antonimiczne (np. 450. Sewus crudelis idem sunt i 451. blandus lagodni).

207 Il più antico dizionario latino-polacco, s. 98.

208 Stowniczek trydencki, 1960-1961, s. 234-236.

209 A. Bańkowski, Wyrazy trudne, s. 246.

${ }^{210}$ Gdyby nie pomyłka kopisty w wyrazie „spicla”, w wyniku której powstało 184. Spica - clossz (zob. wyżej), ciąg ten byłby nieprzerwany i liczyłby 10 haseł. 
Kategoria paronimiczna przywodzi na myśl takie rodzaje średniowiecznych dzieł leksykograficznych jak distinctiones, czyli słowniki wyszczególniające różne znaczenia wyrazów, oraz equivoca, czyli słowniki homonimów i paronimów. Obejmuje 31 zestawień, które częściowo zachodzą na kategorię onomazjologiczną, np. w zestawieniu 137. falx sirp - 138. falcastrum kossa, do którego dołączono jeszcze 139. faux celuscz, należące do zupełnie innej dziedziny (części ciała). Zgrupowania należące do tej kategorii nigdy nie przekraczają trzech haseł. Niektóre odnoszą się do wyrazów wieloznacznych (np. 364. Cyclas est nobilis pannus uel uestis et eciam est proprium nomen insule in mari; 395. Anceps gladius ex utroque scindens - 396. anceps dubius sermo; 368. Vber vyme - 369. Vber plodni), inne tylko do wyrazów podobnych brzmieniowo, w większym lub mniejszym stopniu (61. Aridarium osnicza-62. Viridarium zagroda; 65. Caries prochno-66. Spurius wileganecz). Najbardziej znamiennym przykładem wśród tych ostatnich jest zestawienie 128. Carist $<i>a$ glod drogoscz - 129. Eukaristia corpus christi, gdzie można odnieść wrażenie, że zupełnie podstawowe hasło drugie zostało dodane wyłącznie w celu mnemotechnicznego skontrastowania z pierwszym. A. Steffen pisał również o paronimii wyrazów polskich ${ }^{211}$, ale jedynym przykładem, i to wątpliwym, jest zestawienie 37. Alueolus muto scobp - 42. Aries scop. Zważywszy, że w wokabularzu wyrazy hasłowe (wyjściowe) zawsze są łacińskie i łacińskie były najprawdopodobniej również źródła, z których korzystał jego twórca, można wykluczyć udział skojarzeń między wyrazami polskimi w powstawaniu słownika.

Także kategoria etymologiczna częściowo zachodzi na dwie pozostałe. Zawiera 20 zestawień dwuwyrazowych oraz dwa hasła objaśnione wyłącznie przy pomocy metody derivatio (110. fauto est actus ex fauendo, 404. Veco $<r>s$ habens ve in corde). W kilku przypadkach pokrewieństwo słowotwórcze zostało zaznaczone określeniami metajęzykowymi (3-4. Cruor posoka Inde cruentatus krawy; 299-300. fera sw<ie $>$ rzø inde ferina swerzina).

Zdarza się, że w obrębie jednej serii wyrazowej pojawiają się relacje należące do różnych kategorii, np. 368. Vber vyme - 369. Vber plodni-370. Mamma apud mulierem-371-372. sterilis lasciuus idem est yalowy - 373. fertilis plodni. Ciąg ten łączy dwie serie tematyczne (części ciała u ludzi i zwierząt: 368 i 370, płodność: 369 i 371-373) oraz zestawienie paronimiczne (368 i 369).

Część zestawień (w tabeli 2 zostały one pogrubione) pochodzi z Graecismusa Eberharda z Béthune, który również łączył onomazjologię $\mathrm{z}$ paronimią $\mathrm{i}$ etymologią. W niektórych przypadkach pokrewieństwo z tym traktatem wyjaśnia kolejność, w jakiej hasła pojawiają się w wokabularzu. Dotyczy to np. omówionego powyżej hasła 184. Spica clossz, ale też zestawień 103. Torus est cuctis bouis in gutture - 104. palea plewa oraz 437. Condimentum vcrasene - 438. sal significat sapientiam 2-modo etc, w których można mówić o „ukrytej” paronimii. W pierwszym przypadku w Graecismusie pojawia się wyraz palearia, będący synonimem wyrazu torus; w drugim, jak już wspomniano, dwuwiersz Eberharda zestawia dwa znaczenia sal - jako condimentum i jako sapientia, z czego twórca wokabularza zachował tylko drugie, pierwsze przekształcając $\mathrm{w}$ osobne hasło $\mathrm{z}$ polskim objaśnieniem.

Porządek haseł w wokabularzu zgadza się mniej więcej z porządkiem w Graecismusie, ale między hasłami przejętymi z tego traktatu pojawia się wiele innych. O ile dość łatwo jest domyślić się powodów, dla których dane wyrazy zostały zgrupowane w kilkuwyrazowe zestawienia, o tyle wyjaśnienie kolejności tych zestawień nastręcza już większych trudności. Można się zastanawiać, czy jakiś wpływ miały tu inne źródła, z których zaczerpnięto słownictwo, czy też jest to efekt samodzielnej działalności twórcy lub twórców słownika.

Makrostruktura wokabularza trydenckiego jest zatem mieszana, nie do końca usystematyzowana i nie w pełni konsekwentna. Składa się z segmentów, które najczęściej obejmują dwa hasła, zestawione na zasadzie kontrastu lub, przeciwnie, podobieństwa, przy czym zestawienia onomazjologiczne przeważają nad semazjologicznymi (paronimicznymi i derywacyjnymi). Poszczególne segmenty ułożone są przynajmniej częściowo w porządku tekstowym, zgodnym z kolejnością, w jakiej objaśniane wyrazy występują w Graecismusie.

\footnotetext{
211 Stowniczek trydencki, 1960-1961, s. 235.
} 


\subsubsection{Funkcja wokabularza}

Nie wszyscy badacze wokabularza zastanawiali się nad jego funkcją i celem zapisania w kodeksie trydenckim. S. Urbańczyk pominął tę kwestię. A. Bańkowski postawił tezę, wedle której ułożony już w Trydencie wokabularz miał rozwiązać problemy w porozumiewaniu się, jakie napotkał biskup i jego świta $\mathrm{w}$ zetknięciu z włoską łaciną, różną od polskiej czy to ze względu na archaiczność trydenckiego dialektu, czy też na wzrastające wpływy humanistów ${ }^{212}$. Z przyczyn wyjaśnionych $\mathrm{w}$ punkcie 2.2 .3 wydaje się to jednak wątpliwe.

Według A. Steffena za przyczynę powstania słownika (które datował na pierwszą połowę XIV w.) należy uznawać „modę, która wpychała się do nas zza granicy”213, sam wokabularz zaś miał być dla jego rozmiłowanego w języku twórcy głównie zabawą intelektualną. Do kodeksu trydenckiego został natomiast przepisany po to, by służyć księciu Aleksandrowi jako materiał dydaktyczny do wykładów dla studentów Uniwersytetu Krakowskiego. Wokabularz miałby wręcz okazać się nieocenioną pomocą w objaśnianiu zawartych w kodeksie formuł dokumentów i listów ${ }^{214}$. Wątpliwości co do wiązania kodeksu z postacią Aleksandra przedstawiono już wyżej (zob. 2.1). Nawet gdyby rzeczywiście był on jego właścicielem, to można powątpiewać, by parał się nauczaniem w czasie swojego honorowego raczej rektoratu. Ponadto w punkcie 2.2.2 ustalono, że materiał leksykograficzny w wokabularzu tylko w niewielkim stopniu dotyczy terminologii prawnej i oficjalnej, a choć pokrywa się częściowo z wyrazami występującymi w głównej, stricte formularzowej części kodeksu, to związki między nimi są znikome (zob. 2.2.3). Być może wokabularz rzeczywiście zwrócił uwagę kopisty albo jego zleceniodawcy ze względu na obecność wyrazów takich jak capitaneus albo reus, ale przecież hasła z tej kategorii stanowią tylko niewielką część słownika, a ich rozproszenie utrudniałoby stosowanie go jako pomocy w przypadku problemów ze zrozumieniem bądź przekładem pozostałych części kodeksu.

Jan Władysław Woś zajął stanowisko przeciwne do A. Steffena: sugerował mianowicie, że słownik miał być pomocą dla Aleksandra na nowym stanowisku w Trydencie, tym potrzebniejszą, że znajomość łaciny mazowieckiego księcia zapewne pozostawiała wiele do życzenia ${ }^{215}$. W innym miejscu badacz ten wyraził przypuszczenie podobne do tezy A. Bańkowskiego, jakoby wokabularz był dowodem problemów komunikacyjnych, w jakimi zmagała się polska kolonia w Trydencie ${ }^{216}$.

Próbę określenia rzeczywistej funkcji wokabularza można podjąć po analizie zawartej w punktach 2.2.2.-2.2.4. Przypomnijmy, że materiał leksykograficzny obecny w wokabularzu jest bardzo zróżnicowany, jednak dominuje $\mathrm{w}$ nim terminologia związana $\mathrm{z}$ życiem codziennym i światem wiejskim oraz słownictwo raczej potoczne niż specjalistyczne. Część haseł pochodzi z Graecismusa, czyli traktatu gramatycznego o przeznaczeniu dydaktycznym, choć prawdopodobnie nie zostały przejęte zeń bezpośrednio, na co wskazują błędy (184. Spica clossz zamiast spicla, 394. Spinx monstrum marinum zamiast Pistrix, 441. fenus est dux usura zamiast duplex usura). Łączenie haseł w krótkie zestawienia tematyczne, paronimiczne lub etymologiczne ma niewątpliwe zalety mnemotechniczne. Wszystkie te cechy wskazują na to, że wokabularz powstał w kontekście szkolnym (może w krakowskim środowisku uniwersyteckim). Oderwanie od pierwotnego tekstu traktatu Eberharda z Béthune oraz obecność wielu haseł pochodzących z innych źródeł wyklucza możliwość, by wokabularz był niejako „słowniczkiem do Graecismusa”. Ograniczona musiała być również jego przydatność w rozwiązywaniu szczegółowych problemów przy lekturze tekstów czy w porozumiewaniu się, a to z uwagi na brak konsekwencji w organizacji treści. Wokabularz miał zapewne pełnić funkcję dydaktyczną jako pomoc do nauczania i uczenia się łaciny, a konkretnie do zapamiętywania słownictwa. Pod tym względem przypomina nominalia, mimo że jego ogólna makrostruktura jest znacznie mniej uporządkowana niż np. Nominalia Aelfrica z Canterbury. Możliwe, że wokabularz był - przynajmniej początkowo - osobistą notatką sporządzoną np. przez

212 A. Bańkowski, Wyrazy trudne, s. 245, 247.

213 Stowniczek trydencki, 1960-1961, s. 232.

214 Tamże, s. 223.

215 J.W. Woś, Alessandro di Masovia, s. 16.

${ }^{216}$ Tenże, Alessandro di Masovia, vescovo di Trento (1423-1444), Trento 2001, s. 10. 
studenta do prywatnego użytku, niekoniecznie zaś materiałem dydaktycznym ułożonym przez profesora, choć nie da się również wykluczyć, że był wykorzystywany na różne sposoby.

Rzeczywista przydatność wokabularza musi pozostać w sferze domysłów. Tak jak trudno nieraz stwierdzić, czy formularze były rzeczywiście stosowane w praktyce kancelaryjnej, tak też trudno orzec, kto i jak intensywnie korzystał z wokabularza, ani dlaczego w ogóle zdecydowano o wpisaniu go do kodeksu trydenckiego. Jedynym śladem czyjegoś zainteresowania jest wspomniana już manikula na marginesie k. 72r, wskazująca nie na którekolwiek z haseł prawniczych, lecz na serię dotyczącą uprzęży.

\section{Podsumowanie}

Analiza wokabularza trydenckiego na tle leksykografii średniowiecznej pozwala określić jego charakter, genezę i przeznaczenie, jak również doprecyzować albo skorygować niektóre powielane w literaturze stwierdzenia. Wydaje się, że należy ostrożniej podchodzić do tezy wiążącej ten zabytek z osobą księcia mazowieckiego Aleksandra i dopuścić możliwość, że kodeks należał np. do Jakuba Zaborowskiego lub Stanisława Sobniowskiego. Za całkowicie bezpodstawne trzeba natomiast uznać zaklasyfikowanie wokabularza do słowników prawniczych.

Podkreślenia wymaga fakt, że wokabularz w kodeksie trydenckim jest kopią, należy zatem oddzielić osobę jego pierwotnego twórcy (lub twórców) od pisarza, który ok. 1420 r. zapełnił karty znanego nam rękopisu, oraz od właściciela (lub właścicieli) kodeksu. Nie sposób stwierdzić, czy dopiero pisarz kodeksu dokonał kompilacji dwóch lub więcej źródeł, czy też przepisał w całości jeden istniejący już słownik. Niezależnie od tego, w którym momencie utworzona została całość znana z wokabularza trydenckiego, wydaje się, że jednym z jej źródeł musiało być dzieło łacińskie - albo glosariusz, albo tylko lista wyrazów wypisanych z Graecismusa Eberharda z Béthune. Korzenie siegające tego popularnego traktatu gramatycznego, a także zbieżności z innymi słownikami z tego okresu pozwalają umieścić wokabularz w obrębie ogólnoeuropejskiej tradycji leksykograficznej, opartej tak jak całe średniowieczne piśmiennictwo na cytatach, zapożyczeniach i przekształceniach w kolejnych kopiach nieuchwytnego oryginału.

Jako najstarszy tak obszerny łacińsko-polski zabytek leksykograficzny wokabularz trydencki może sprawiać wrażenie pierwociny gatunku, o nie w pełni jeszcze wykształconych formach i nie zawsze konsekwentnej konstrukcji. Możliwe jest jednak ustalenie celu, jaki najprawdopodobniej przyświecał jego twórcy. Słownictwo dotyczące $\mathrm{w}$ większości życia codziennego i świata wiejskiego, w niewielkim zaś tylko stopniu specjalistyczne, a przy tym częściowo zaczerpnięte z dydaktycznego traktatu gramatycznego, wskazuje na przynależność wokabularza do nurtu słowników szkolnych, przeznaczonych dla osób, które dopiero poznają łacinę. Na dydaktyczno-szkolny charakter wokabularza trydenckiego wskazuje również jego mnemotechniczna struktura, w której pobrzmiewają echa nominaliorum, equivocorum i distinctionum. Z dużym prawdopodobieństwem przypuszczać można, że powstał w środowisku uniwersyteckim, do kodeksu trydenckiego mógł zaś zostać wpisany jako rzecz przynajmniej teoretycznie przydatna dydaktycznie, na równi z wzorami listów i dokumentów, spisem formuł adresatywnych czy schematami dotyczącymi teorii retoryki.

Analiza wokabularza trydenckiego uwydatniła potrzebę dalszych, pogłębionych badań nad polskimi słownikami średniowiecznymi, które pozostają dziedziną słabo opisaną, często zbywaną ogólnikowymi, a czasem nawet nieścisłymi odwołaniami do dawniejszej literatury przedmiotu. Można wręcz zaryzykować stwierdzenie, że tak jak polska leksykografia w średniowieczu była opóźniona w stosunku do leksykografii zachodnioeuropejskiej, tak i dzisiaj badania nad nią pozostają w tyle. Konieczne jest przede wszystkim sporządzenie wyczerpującego wykazu zachowanych słowników łacińsko-polskich (i odróżnienie ich od słowników łacińskich z okazjonalnymi glosami polskimi), co pozwoliłoby zorientować się w rozmiarach i zróżnicowaniu całego zjawiska. Niezbędne są również badania nad poszczególnymi słownikami, i to nie tylko nad zawartym w nich słownictwem, do czego często ograniczają się zainteresowania filologów, ale też nad ich mikro- i makrostrukturą, możliwymi do zidentyfikowania źródłami i okolicznościami powstania. Próba takiej całościowej analizy podjęta w niniejszym artykule pozwoliła pełniej scharakteryzować wokabularz trydencki, stanowiąc przyczynek do poznania tendencji intelektualnych i dydaktycznych w Polsce w pierwszej połowie XV w. 


\section{Aneks}

Tabela 1. Zbieżności wokabularza trydenckiego z Graecismusem Eberharda z Béthune oraz trzema wybranymi słownikami z XIV-XV w.

\begin{tabular}{|c|c|c|c|c|}
\hline Graecismus $^{217}$ & $\begin{array}{c}\text { Slowniczek } \\
\text { świętowicki }{ }^{218}\end{array}$ & $\begin{array}{c}\text { BJ, } \\
\text { rkps } 228^{219}\end{array}$ & $\begin{array}{c}\text { Rkps } \\
\text { Lat.I.F.ch.254 } \\
\end{array}$ & $\begin{array}{l}\text { Wokabularz } \\
\text { trydencki }^{221}\end{array}$ \\
\hline $\begin{array}{l}\text { 10) } 62 . \text { Purgat equum strigilis; strigilis } \\
\text { quoque ferrea cratis [113] }\end{array}$ & & & & 2. Strigillis grzeblo \\
\hline $\begin{array}{l}\text { 9) } 5 \text {. Sanguis alit corpus: cruor est } \\
\text { a corpore fusus / } 6 \text {. Extractus venis: } \\
\text { cruor est in corpore sanguis [85] }\end{array}$ & & $\begin{array}{l}\text { 135. cruor } \\
\text { possoka }\end{array}$ & 99. cruor poszoka & 3. Cruor posoka \\
\hline $\begin{array}{l}\text { 9) 7. Pupillus matre caret: orphanus } \\
\text { est sine patre [85] }\end{array}$ & & & & $\begin{array}{l}\text { 5. pupillus siro } \\
\text { ta (i.e. carens matre) }\end{array}$ \\
\hline $\begin{array}{l}\text { 9) } 6 . \text { Orphanus ac proprie magis est } \\
\text { privatus utroque [85] }\end{array}$ & $\begin{array}{l}\text { 188. Orphanus } \\
\text { syrotek }\end{array}$ & & & $\begin{array}{l}\text { 6. Orphanus carens } \\
\text { utroque }\end{array}$ \\
\hline $\begin{array}{l}\text { 9) } 9 . \text { Rure fugo lepores [85] // } 157 \text {. } \\
\text { Rusticus a rure quoniam rus est sibi } \\
\text { cure [94] }\end{array}$ & & & 304. rus karcz & 7. rus pole \\
\hline 9)17. Presentat dapifer epulas [86] & & & $\begin{array}{l}\text { 202. dapifer } \\
\text { stolnyk }\end{array}$ & 8. dapiffer postole \\
\hline $\begin{array}{l}\text { 9) } 18 \text {. Estque senescalus cuius sit sub } \\
\text { duce iussus [86] }\end{array}$ & $\begin{array}{l}\text { 344. Senascalus } \\
\text { Marssalek }\end{array}$ & $\begin{array}{l}\text { 736. senascalus } \\
\text { marszalek }\end{array}$ & & $\begin{array}{l}\text { 9. Senascallus } \\
\text { marsalek }\end{array}$ \\
\hline $\begin{array}{l}\text { 9) } 20 \text {. Anteque signarius idem solet esse } \\
\text { vocatus [86] }\end{array}$ & & & & $\begin{array}{l}\text { 10. Vexilifer } \\
\text { an }<\text { te }>\text { signarius } \\
\text { chorøsze }\end{array}$ \\
\hline $\begin{array}{l}\text { 9) 19. Primipylus notat in bellis vexilla } \\
\text { ferentem [86] }\end{array}$ & & & & $\begin{array}{l}\text { 11. primipillus primus } \\
\text { sagittarius in bello }\end{array}$ \\
\hline \multirow[t]{4}{*}{$\begin{array}{l}\text { 9) } 21 \text {. Ac lictor signans vindictam } \\
\text { prevehit ensem [86] }\end{array}$} & & $\begin{array}{l}519 . \text { lictor qui } \\
\text { portat gladium } \\
\text { regis }\end{array}$ & $\begin{array}{l}\text { 369. 1litor } \\
\text { oprzawcza }\end{array}$ & $\begin{array}{l}\text { 12. lictor qui portat } \\
\text { gladium ante regem }\end{array}$ \\
\hline & & $\begin{array}{l}\text { 792. sangwissuga } \\
\text { pyawycza }\end{array}$ & & $\begin{array}{l}\text { 13. Sang }<\text { ui }>\text { suga } \\
\text { pyavicza }\end{array}$ \\
\hline & $\begin{array}{l}\text { 124. papilla } \\
\text { bradawyczye }\end{array}$ & & & $\begin{array}{l}\text { 15. pupilla nodulus } \\
\text { circa mamam }\end{array}$ \\
\hline & $\begin{array}{l}\text { 76. pupilla } \\
\text { zrzyedlnycze }\end{array}$ & $\begin{array}{l}\text { 675. pupilla } \\
\text { powyeczka }\end{array}$ & 334. ? zrenycza & $\begin{array}{l}\text { 16. pupilla szrenicza } \\
\text { oculi }\end{array}$ \\
\hline $\begin{array}{l}\text { 9) 40. Dicitur in causis iudex; in lite } \\
\text { sequester [87] }\end{array}$ & & $\begin{array}{l}\text { 785. sequester } \\
\text { roswadzacz }\end{array}$ & & $\begin{array}{l}\text { 17. sequester qui } \\
\text { diuidit litem }\end{array}$ \\
\hline $\begin{array}{l}\text { 9) } 81 \text {. Dicatur gelima manibus } \\
\text { pedibusque ligata [90] }\end{array}$ & & & & $\begin{array}{l}\text { 18. gelima wal trawi } \\
\text { uel feni }\end{array}$ \\
\hline
\end{tabular}

217 Pierwsza liczba - z nawiasem okrągłym - oznacza numer rozdziału, druga - z kropką - numer wiersza. Wszystkie cytaty pochodzą ze zdygitalizowanego inkunabułu Graecismus cum commento z 1487-1488 r., dostępnego na stronie: $<$ https:// archive.org/details/OEXV571_P2> [dostęp: 16.05.2018]. Liczba w nawiasie kwadratowym oznacza numer strony w tym wydaniu.

218 Słownik z końca XIV w. zawarty na k. 91r-95v rkps. D 84 z zasobu rękopisów biblioteki kapituły katedry św. Wita w Archiwum Zamku Praskiego; edycja: Svatovitský rukopis, wyd. A. Patera, Praha 1886, s. 312-322. Numeracja własna, w edycji hasła są nienumerowane.

${ }^{219}$ Katalog rękopisów Biblioteki Uniwersytetu Jagiellońskiego, cz. 1, wyd. W. Wisłocki, Cracoviae 1877-1881, s. 84-89. Numeracja własna, w edycji hasła sa nienumerowane.

${ }^{220}$ A. Brückner, Neue Quellen, s. 488-496; tenże, Z rękopisów petersburskich, s. 17. Numeracja własna, w edycji hasła są nienumerowane. Znak zapytania oznacza, że A. Brückner pominął wyraz łaciński.

${ }^{221}$ Numeracja według wydania S. Urbańczyka. 


\begin{tabular}{|c|c|c|c|c|}
\hline Graecismus & $\begin{array}{l}\text { Słowniczek } \\
\text { świętowicki }\end{array}$ & $\begin{array}{l}\text { BJ, } \\
\text { rkps } 228\end{array}$ & $\begin{array}{c}\text { Rkps } \\
\text { Lat.I.F.ch.254 }\end{array}$ & $\begin{array}{l}\text { Wokabularz } \\
\text { trydencki }\end{array}$ \\
\hline & & 284. exaccio szosz & & 21. Exaccio pobor \\
\hline $\begin{array}{l}\text { 9) 103. Qui solet accipere sub rege } \\
\text { tributa tribunus [91] }\end{array}$ & & & & 19. Tribunus bercza \\
\hline $\begin{array}{l}\text { 9) 103. Qui solet accipere sub rege } \\
\text { tributa tribunus [91] }\end{array}$ & & $\begin{array}{l}\text { 798. tributum } \\
\text { poradlne i.e. porąp }\end{array}$ & $\begin{array}{l}\text { 652. tributum } \\
\text { poradlnye; } 663 . \\
\text { tributum porab }\end{array}$ & 22. Tributum berna \\
\hline $\begin{array}{l}\text { 9) } 91 \text {. Assensum dictis consensum dic } \\
\text { fore factis [90] }\end{array}$ & & & & $\begin{array}{l}\text { 23. Consensus et } \\
\text { assensus id est } \\
\text { powolene }\end{array}$ \\
\hline $\begin{array}{l}\text { 9) 104. Auctor ab augendo nomen trahit } \\
\text { [91] }\end{array}$ & & & $\begin{array}{l}\text { 218. autor } \\
\text { szląwyanthny }\end{array}$ & 24. Autor slawatni \\
\hline $\begin{array}{l}\text { 9) 112. Duricies manuum callus [92] // } \\
\text { 12) 35. Callus duricies [137] }\end{array}$ & & $\begin{array}{l}\text { 182. callus } \\
\text { modzel vel via }\end{array}$ & $\begin{array}{l}\text { 106. callus } \\
\text { modzel }\end{array}$ & 25. Callus modzel \\
\hline $\begin{array}{l}\text { 9) 112. callis via stricta [92]; 12) } 35 \text {. } \\
\text { dicatur semita callis [137] }\end{array}$ & & $\begin{array}{l}\text { 185. callis twarda } \\
\text { droga }\end{array}$ & & 26. Callis goscinecz \\
\hline 9) 113. Dic collem montem [92] & & $\begin{array}{l}\text { 178. collis } \\
\text { przigorek }\end{array}$ & 374. ? pagorzek & 27. Collis pagorek \\
\hline $\begin{array}{l}\text { 9) 109. In dorso gibbus: in pectore } \\
\text { gibber habetur [92] }\end{array}$ & & & & $\begin{array}{l}\text { 28. In dorso gibus } \\
\text { In pectore giber }\end{array}$ \\
\hline $\begin{array}{l}\text { 9) 111. Gibbus terga premit pectore } \\
\text { struma tumet [91] }\end{array}$ & 99. Struma wole & & & 29. struna wol \\
\hline \multirow[t]{2}{*}{$\begin{array}{l}\text { 9) 116. Denotat officium scriptor: } \\
\text { scribaque magistrum [92] }\end{array}$} & & & & $\begin{array}{l}\text { 30. Scriba dicitur } \\
\text { magister }\end{array}$ \\
\hline & & 565. menda blisna & 359. ? pyega & $\begin{array}{l}\text { 33. lentigo menda } \\
\text { pega }\end{array}$ \\
\hline \multirow[t]{3}{*}{ 9) 118. Discus scutella tibi sit [92] } & & & $\begin{array}{l}\text { 127. discus } \\
\text { krzynow }\end{array}$ & 34. Discus crzinow \\
\hline & 617. Capete kopa & & & 35. Capistrum copana \\
\hline & 285. Canale zleb & 141. canale rina & & $\begin{array}{l}\text { 36. Canale slob uel } \\
\text { rinna }\end{array}$ \\
\hline $\begin{array}{l}\text { 9) } 129 . \text { Et quia sit mutus poterit bene } \\
\text { muto vocari [93] }\end{array}$ & & & $\begin{array}{l}\text { 614. mulsum } \\
\text { skopyecz }\end{array}$ & $\begin{array}{l}\text { 37. Alueolus muto } \\
\text { scobp }\end{array}$ \\
\hline $\begin{array}{l}\text { 9) } 178 . \text { Est veredus equus vectans } \\
\text { redam quasi currum [96] }\end{array}$ & & & 364. reda szlya & 38. Reda sla \\
\hline $\begin{array}{l}\text { 9) } 178 \text {. Est veredus equus vectans } \\
\text { redam quasi currum [96] }\end{array}$ & & & & 39. Veredus wosnik \\
\hline $\begin{array}{l}\text { 9) } 131 \text {. Nominis huius equus est equo } \\
\text { caput; ratioque / } 132 \text {. Dicitur a currus } \\
\text { antiquo more trahendi / } 133 \text {. Quod pede } \\
\text { tellurem solet ipsem cavare caballus [93] }\end{array}$ & $\begin{array}{l}\text { 441. Cabella } \\
\text { kobyla }\end{array}$ & & $\begin{array}{l}\text { 254. caballus } \\
\text { szkapa }\end{array}$ & 40. Caballus scapa \\
\hline $\begin{array}{l}\text { 9) 127. Est aries dictus quia sit } \\
\text { mactatus ad aras / } 128 \text {. Vel quia grex } \\
\text { fortis aries dicatur ab ares [93] }\end{array}$ & $\begin{array}{l}\text { 462. Aries } \\
\text { skopecz }\end{array}$ & & & 42. Aries scop \\
\hline $\begin{array}{l}\text { 9) 136. Inde gradarius est qui pede } \\
\text { mollis eat [93] }\end{array}$ & & $\begin{array}{l}\text { 388. gradarius } \\
\text { drabarz }\end{array}$ & $\begin{array}{l}\text { 255. gradarius } \\
\text { drabarz }\end{array}$ & $\begin{array}{l}\text { 44. Gradarius } \\
\text { drabarzy }\end{array}$ \\
\hline \multirow[t]{2}{*}{$\begin{array}{l}\text { 9) 122. Libertate carens colibertus } \\
\text { dicitur esse [93] }\end{array}$} & & & & $\begin{array}{l}\text { 45. Colibertus } \\
\text { nevolni }\end{array}$ \\
\hline & $\begin{array}{l}\text { 439. Ambulator } \\
\text { mymochodnyk }\end{array}$ & $\begin{array}{l}\text { 68. ambulator } \\
\text { mymochodnyk }\end{array}$ & $\begin{array}{l}\text { 256. ambulator } \\
\text { yvnochothnyk / } \\
682 \text {. ambulator } \\
\text { yvnochodnyk }\end{array}$ & $\begin{array}{l}\text { 47. Ambulator } \\
\text { polefredus } \\
\text { junochodnik }\end{array}$ \\
\hline
\end{tabular}




\begin{tabular}{|c|c|c|c|c|}
\hline Graecismus & $\begin{array}{l}\text { Słowniczek } \\
\text { świętowicki }\end{array}$ & $\begin{array}{c}\text { BJ, } \\
\text { rkps } 228\end{array}$ & $\begin{array}{c}\text { Rkps } \\
\text { Lat.I.F.ch.254 }\end{array}$ & $\begin{array}{l}\text { Wokabularz } \\
\text { trydencki }\end{array}$ \\
\hline & & & 73. ? kolepka & $\begin{array}{l}\text { 48. Cunabulus } \\
\text { Colebka }\end{array}$ \\
\hline $\begin{array}{l}\text { 9) } 152 . \text { meretricum sit tibi leno [94] // } \\
\text { 12) } 22 \text {. Fornix lenonis locus est pariter } \\
\text { meretricis [136] }\end{array}$ & & $\begin{array}{l}\text { 525. leno } \\
\text { porobnik }\end{array}$ & & 49. leno porobni \\
\hline \multirow[t]{3}{*}{$\begin{array}{l}\text { 9) } 153 \text {. Intentusque gule parasitus } \\
\text { dicitur esse [94] }\end{array}$} & & $\begin{array}{l}\text { 683. parasitus } \\
\text { passyrzit }\end{array}$ & & 50. parasitus pasiszit \\
\hline & & & $\begin{array}{l}\text { 222. hystrio } \\
\text { spylman }\end{array}$ & 51. histrio spilman \\
\hline & & $\begin{array}{l}\text { 681. prestigiator } \\
\text { kuglerz }\end{array}$ & & $\begin{array}{l}\text { 52. prestigiator } \\
\text { cuglarz }\end{array}$ \\
\hline $\begin{array}{l}\text { 9) } 169 \text {. Pars prior est cortex liber altera } \\
\text { tertia suber [95] }\end{array}$ & & & & 55. Cortex scora \\
\hline $\begin{array}{l}\text { 9) 170. Equivoce vinumque latex et } \\
\text { limpha vocatur / 171. Et idcirco latex } \\
\text { vinum quoniam latet uva / 172. Limpha } \\
\text { latex ideo quoniam terre latet imo [95] } \\
\text { // 12) 159. Dicitur inde latex quoniam } \\
\text { lateat [153] }\end{array}$ & & & & $\begin{array}{l}\text { 56. latex, aqua } \\
\text { currens sub terra }\end{array}$ \\
\hline $\begin{array}{l}\text { 9) 170. Equivoce vinumque latex et } \\
\text { limpha vocatur / 171. Et idcirco latex } \\
\text { vinum quoniam latet uva / 172. Limpha } \\
\text { latex ideo quoniam terre latet imo [95] } \\
/ / \text { 10) } 258 \text {. Fontis limpha [126] }\end{array}$ & & & & $\begin{array}{l}\text { 57. limpha, aqua } \\
\text { fontanea }\end{array}$ \\
\hline $\begin{array}{l}\text { 9) } 177 \text {. Virgulti custos homo dicitur } \\
\text { esse viredus [96] }\end{array}$ & & & $\begin{array}{l}\text { 678.virgultum } \\
\text { przath }\end{array}$ & $\begin{array}{l}\text { 58. Virgultum } \\
\text { zapusta }\end{array}$ \\
\hline \multirow{7}{*}{$\begin{array}{l}\text { 12) 122. sit lucus a luceo quod sit } \\
\text { opacus / 123. Sicque per antifrasim } \\
\text { dices a luceo lucum [143] }\end{array}$} & 536. lucus luh & & 300. lucus gąscz & 59. lucus gay \\
\hline & $\begin{array}{l}\text { 287. Aridarium } \\
\text { polyczye }\end{array}$ & & & $\begin{array}{l}\text { 61. Aridarium } \\
\text { osnicza }\end{array}$ \\
\hline & $\begin{array}{l}\text { 47. viridarium } \\
\text { trawnyk }\end{array}$ & & & $\begin{array}{l}\text { 62. Viridarium } \\
\text { zagroda }\end{array}$ \\
\hline & & & 89. ? chomatho & $\begin{array}{l}\text { 63. Colependium } \\
\text { chomato }\end{array}$ \\
\hline & & 550. longale oge & & 64. longale onicze \\
\hline & & $\begin{array}{l}\text { 168. caries } \\
\text { prochno }\end{array}$ & 67. ? prochno & 65. Caries prochno \\
\hline & $\begin{array}{l}\text { 213. Spurius } \\
\text { zenynycz }\end{array}$ & & & $\begin{array}{l}\text { 66. Spurius } \\
\text { wileganecz }\end{array}$ \\
\hline \multirow[t]{2}{*}{$\begin{array}{l}\text { 9) 202. Capreolus vero siluestris dicitur } \\
\text { esse [97] }\end{array}$} & & & & 68. Capreolus sarn \\
\hline & 264. Olus zele & & & 69. olus ger \\
\hline 12) 34. Dic caules olera [137] & & & & 70. olera - odrosly \\
\hline $\begin{array}{l}\text { 9) } 216 \text {. Dicas textoris radium. Radium } \\
\text { quoque solis / } 217 \text { Atque rote radius tibi } \\
\text { sit non invenio plus [99] }\end{array}$ & $\begin{array}{l}\text { 600. radius } \\
\text { stpiczye }\end{array}$ & $\begin{array}{l}\text { 712. radius } \\
\text { promyen }\end{array}$ & & 74. Radius plomen \\
\hline $\begin{array}{l}\text { 9) } 231 \text {. Est testudo balistaque } \\
\text { semicirculus est as [101] }\end{array}$ & $\begin{array}{l}\text { 494. Testudo } \\
\text { hlemyzd }\end{array}$ & $\begin{array}{l}\text { 796. testudo slep, } \\
\text { sklep }\end{array}$ & & 76. Testudo sclep \\
\hline
\end{tabular}




\begin{tabular}{|c|c|c|c|c|}
\hline Graecismus & $\begin{array}{l}\text { Słowniczek } \\
\text { świętowicki }\end{array}$ & $\begin{array}{l}\text { BJ, } \\
\text { rkps } 228\end{array}$ & $\begin{array}{c}\text { Rkps } \\
\text { Lat.I.F.ch.254 }\end{array}$ & $\begin{array}{l}\text { Wokabularz } \\
\text { trydencki }\end{array}$ \\
\hline & & $\begin{array}{l}\text { 668. pauimentum } \\
\text { podloga }\end{array}$ & & $\begin{array}{l}\text { 77. pauimentum } \\
\text { podloga }\end{array}$ \\
\hline & $\begin{array}{l}\text { 238. procus } \\
\text { dyewosnub }\end{array}$ & $\begin{array}{l}\text { 662. procus } \\
\text { frigerz }\end{array}$ & $\begin{array}{l}\text { 192. procus } \\
\text { dzewoslab }\end{array}$ & 79. procus dewoslab \\
\hline & & $\begin{array}{l}\text { 787. subagazo } \\
\text { potkonye }\end{array}$ & $\begin{array}{l}\text { 205. subagaso } \\
\text { pothkonye }\end{array}$ & $\begin{array}{l}\text { 81. Subagazo } \\
\text { podkone }\end{array}$ \\
\hline 9) 258. ovium sit opilio pastor [102] & & $\begin{array}{l}625 . \text { opilio } \\
\text { ofczarz sc. } \\
\text { gregarius, est } \\
\text { nomen generale } \\
\text { ad illa omnia }\end{array}$ & & $\begin{array}{l}\text { 82. opilio pastor } \\
\text { ovium }\end{array}$ \\
\hline $\begin{array}{l}\text { 9) } 272 \text {. Ast ecatontarcha seu vis } \\
\text { centurio centum / 273. possidet; }\end{array}$ & & & & $\begin{array}{l}\text { 83. Centurio qui } \\
\text { possidet centum }\end{array}$ \\
\hline $\begin{array}{l}\text { 9) 273. ac mille dux chiliarcha tenet } \\
\text { [103] }\end{array}$ & & & & $\begin{array}{l}\text { 84. Ciliarcha qui } \\
\text { possidet mille }\end{array}$ \\
\hline $\begin{array}{l}\text { 9) 278. Incantatores serpentum dicimus } \\
\text { esse [103] }\end{array}$ & & & & $\begin{array}{l}\begin{array}{l}\text { 85. Incatator } \\
\text { czarounik }\end{array} \\
\end{array}$ \\
\hline \multirow[t]{3}{*}{$\begin{array}{l}\text { 9) } 280 \text {. Bos est camporum; bubalus est } \\
\text { nemorum [104] }\end{array}$} & 459. Bubalus zubr & & & 87. bubalus thur \\
\hline & & $\begin{array}{l}\text { 145. causidicus } \\
\text { rzecznik }\end{array}$ & $\begin{array}{l}\text { 690. causidicus } \\
\text { przecznyk }\end{array}$ & $\begin{array}{l}\text { 88. Causidicus } \\
\text { prawedlnik }\end{array}$ \\
\hline & & $\begin{array}{l}\text { 650. prelocutor } \\
\text { rzecznik }\end{array}$ & $\begin{array}{l}\text { 691. prolocutor } \\
\text { rzecznyk }\end{array}$ & $\begin{array}{l}\text { 89. prelocutor } \\
\text { rzecznik }\end{array}$ \\
\hline 9) $104 / 105$. ast ab agendo actor [91] & & & & 91. Actor powod \\
\hline $\begin{array}{l}\text { 9) } 299 . \text { Aera dic nostrum sed dicas } \\
\text { ethera sursum [105] }\end{array}$ & & & & 92. Ether est celum \\
\hline \multirow[t]{4}{*}{$\begin{array}{l}\text { 9) } 318 \text {. Dicatur catulus minimus canis } \\
\text { a cane dictus / } 319 / \text { a cato dictus catus } \\
\text { erit minimus [106] }\end{array}$} & $\begin{array}{l}\text { 473. Catulus } \\
\text { stenye }\end{array}$ & & & 93. Catulus scenø \\
\hline & $\begin{array}{l}\text { 481. Murilegus } \\
\text { koczur }\end{array}$ & & & 94. Murilegus coth \\
\hline & 29. pilum gystba & & & 95. pilum strala \\
\hline & $\begin{array}{l}\text { 155. Talus } \\
\text { czlanek }\end{array}$ & 808. talus gloszn & 355. talus gloszn & 96. talus costka \\
\hline \multirow[t]{2}{*}{$\begin{array}{l}\text { 9) 322. Lanas et telas pecten parat } \\
\text { atque capillos / } 323 \text {. Pubes et piscis } \\
\text { litque chorea tibi [107] }\end{array}$} & & & & $\begin{array}{l}\text { 97. pubes inferior } \\
\text { barba }\end{array}$ \\
\hline & $\begin{array}{l}594 . \text { vector } \\
\text { wozatay }\end{array}$ & & & 98. Vector czolnek \\
\hline $\begin{array}{l}\text { 10) } 20 \text {. De tenui factam corio galeam } \\
\text { voco mitram }[110] / / 12) 110 \text {. Hec } \\
\text { cassis galeam dicas [143] }\end{array}$ & & $\begin{array}{l}\text { 392. galea helm / } \\
\text { 873. galea helm }\end{array}$ & & 100. galea helm \\
\hline $\begin{array}{l}\text { 9) 332. Esse thoros dicas tauri palearia } \\
\text { [107] }\end{array}$ & & & 244. ? byk & $\begin{array}{l}\text { 102. taurus bik uel } \\
\text { celecz }\end{array}$ \\
\hline \multirow[t]{2}{*}{$\begin{array}{l}\text { 9) 332. Esse thoros dicas tauri palearia } \\
\text { [107] }\end{array}$} & & & & $\begin{array}{l}\text { 103. Torus est cuctis } \\
\text { bouis in gutture }\end{array}$ \\
\hline & 254. palea pleua & & & 104. palea plewa \\
\hline $\begin{array}{l}\text { 12) } 79 . \text { Ex usu portus acus et lacus et } \\
\text { tribus inde / } 80 \text {. Ante bus u teneant arc } \\
\text { art part ex ratione [147] }\end{array}$ & & & & 105. Acus oscz \\
\hline
\end{tabular}




\begin{tabular}{|c|c|c|c|c|}
\hline Graecismus & $\begin{array}{l}\text { Słowniczek } \\
\text { świętowicki }\end{array}$ & $\begin{array}{l}\text { BJ, } \\
\text { rkps } 228\end{array}$ & $\begin{array}{c}\text { Rkps } \\
\text { Lat.I.F.ch.254 }\end{array}$ & $\begin{array}{l}\text { Wokabularz } \\
\text { trydencki }\end{array}$ \\
\hline \multirow[t]{2}{*}{$\begin{array}{l}\text { 9) 332. Esse thoros dicas tauri palearia } \\
\text { [107] }\end{array}$} & & & & 106. palearia plewna \\
\hline & & $\begin{array}{l}\text { 752. spica } \\
\text { powrzoslo }\end{array}$ & & 107. Spica klos \\
\hline $\begin{array}{l}\text { 9) } 334 \text {. Est avus et proavus; abavus; } \\
\text { atavus; tritavusque [107] }\end{array}$ & 202. Avus dyed & & & 108. Awus daczd \\
\hline $\begin{array}{l}\text { 9) } 334 \text {. Est avus et proavus; abavus; } \\
\text { atavus; tritavusque [107] }\end{array}$ & $\begin{array}{l}\text { 203. Abavus } \\
\text { pradyed }\end{array}$ & & & 109. Atauus pradad \\
\hline \multirow[t]{2}{*}{ 9) 336. A faveo fautor [108] } & & & & $\begin{array}{l}\text { 110. fauto est actus } \\
\text { ex fauendo }\end{array}$ \\
\hline & & 187. crater rost & & $\begin{array}{l}\text { 111. Crater magnus } \\
\text { ciphus }\end{array}$ \\
\hline $\begin{array}{l}\text { 10) } 12 \text {. Anchora lintea velaque carbasa } \\
\text { sive cherucus / } 13 \text {. Contus seu remus } \\
\text { amplustreque transtra rudentes [109] }\end{array}$ & & $\begin{array}{l}\text { 79. amplustre } \\
\text { paczmi }\end{array}$ & $\begin{array}{l}\text { 15. amplustra } \\
\text { paczyna lodna }\end{array}$ & $\begin{array}{l}\text { 114. Amplustra } \\
\text { paczina }\end{array}$ \\
\hline $\begin{array}{l}\text { 10) } 12 \text {. Anchora lintea velaque carbasa } \\
\text { sive cherucus / } 13 \text {. Contus seu remus } \\
\text { amplustreque transtra rudentes [109] }\end{array}$ & & & & 115. anchora eciam \\
\hline $\begin{array}{l}\text { 10) } 12 \text {. Anchora lintea velaque carbasa } \\
\text { sive cherucus / } 13 \text {. Contus seu remus } \\
\text { amplustreque transtra rudentes [109] }\end{array}$ & & & & 116. Carbasus lodza \\
\hline $\begin{array}{l}\text { 10) } 21 \text {. De puro calibe cassida dic } \\
\text { proprie }[110] / / 12) 110 \text {. Hec cassis } \\
\text { galeam dicas }[143]\end{array}$ & & & & $\begin{array}{l}\text { 118-119. Cassis } \\
\text { clobucek uel alio } \\
\text { nomine helm }\end{array}$ \\
\hline 10) 58. Muscipule murum sunt [113] & & & & $\begin{array}{l}\text { 123. muscipula } \\
\text { sameka? }\end{array}$ \\
\hline 10) 58. decipuleque luporum [113] & & $\begin{array}{l}\text { 270. decipula } \\
\text { stąpa luporum }\end{array}$ & & $\begin{array}{l}\text { 124. decipula } \\
\text { stąpicza }\end{array}$ \\
\hline $\begin{array}{l}\text { 10) } 62 . \text { Purgat equum strigilis; strigilis } \\
\text { quoque ferrea cratis [113] }\end{array}$ & & & & 125. Strigillis rost \\
\hline $\begin{array}{l}\text { 10) } 99 . \text { Dic auri spumam; scoriam dicas } \\
\text { fore ferri [115] }\end{array}$ & & $\begin{array}{l}\text { 750. scorea } \\
\text { zuzelicza }\end{array}$ & $\begin{array}{l}\text { 640. scoria } \\
\text { zuzelicza }\end{array}$ & 127. scorea zuzelicza \\
\hline \multirow[t]{2}{*}{$\begin{array}{l}\text { 9) } 175 . \text { Dicitur hinc cignus quia cantus } \\
\text { congruus eius / 176. Quodtotus candet } \\
\text { ipse vocatur olor [96] }\end{array}$} & & & & 131. Olor dropa \\
\hline & & & $\begin{array}{l}\text { 471. stripla } \\
\text { garleda sucadium } \\
\text { kwaszenyna }\end{array}$ & $\begin{array}{l}\text { 132. Scriffa } \\
\text { quasenina }\end{array}$ \\
\hline $\begin{array}{l}\text { 9) } 25 \text {. Est nati stirps mascla nepos est } \\
\text { luxuriosus [86] // 10) 182. Stirps ambit } \\
\text { prosapia [122] // 12) 203. Stirps de } \\
\text { progenie; stirps radix dicitur esse / } 204 \text {. } \\
\text { Arboribus dabitur hic stirps; animalibus } \\
\text { hec stirps [157] }\end{array}$ & 513. Stirps kmen & & & 133. Stirps pokolene \\
\hline $\begin{array}{l}\text { 10) } 16 \text {. Est mater vidua si sit viduata } \\
\text { marito [109] }\end{array}$ & $\begin{array}{l}\text { 245. vidua } \\
\text { wdowa }\end{array}$ & & & 135. Vidua wdowa \\
\hline $\begin{array}{l}\text { 10) 199. Si proprie attendas parva est } \\
\text { virguncula virgo / 200. illibata viro } \\
\text { virgo est; matrona virago [123] }\end{array}$ & $\begin{array}{l}\text { 190. virago } \\
\text { musyczye }\end{array}$ & & $\begin{array}{l}\text { 197. virago } \\
\text { mazathka }\end{array}$ & 136. Virago masatka \\
\hline 10) 233. Falx metit aut scindit [125] & 294. Falx srp & & & 137. falx sirp \\
\hline
\end{tabular}




\begin{tabular}{|c|c|c|c|c|}
\hline Graecismus & $\begin{array}{l}\text { Słowniczek } \\
\text { świętowicki }\end{array}$ & $\begin{array}{l}\text { BJ, } \\
\text { rkps } 228\end{array}$ & $\begin{array}{l}\text { Rkps } \\
\text { Lat.I.F.ch.254 }\end{array}$ & $\begin{array}{l}\text { Wokabularz } \\
\text { trydencki }\end{array}$ \\
\hline & $\begin{array}{l}\text { 295. Callastrum } \\
\text { kosa }\end{array}$ & & & 138. falcastrum kossa \\
\hline \multirow[t]{2}{*}{ 10) 233. faux quoque mandit [125] } & & & $\begin{array}{l}\text { 336. ffaux } \\
\text { obuscze }\end{array}$ & 139. faux celuscz \\
\hline & & & $\begin{array}{l}533 \text { aurile } \\
\text { panthlyk }\end{array}$ & 143. Aurile patlik \\
\hline $\begin{array}{l}\text { 10) } 256 \text {. Siren trahit; undit scilla; } \\
\text { voratque caribdis [125] }\end{array}$ & & & 113. ? othchlan & 144. Caribdis otclan \\
\hline \multirow{4}{*}{$\begin{array}{l}\text { 12) 93. sed cedens sub frigiditate calori } \\
\text { / } 94 \text {. Est puteus locus intus habens } \\
\text { latices gravis haustu [148] }\end{array}$} & & & & 145.puteus srzodlo \\
\hline & & $\begin{array}{l}\text { 664. passus } \\
\text { craczey }\end{array}$ & $\begin{array}{l}\text { 707. passus } \\
\text { kraczyey }\end{array}$ & 146. passus cracay \\
\hline & 584. Iuger gytro & $\begin{array}{l}\text { 554. mansus } \\
\text { wloka, lon }\end{array}$ & & 147. Juger wreczen \\
\hline & & $\begin{array}{l}828 . \text { vectigal } \\
\text { hurlom }\end{array}$ & & 152. Vectigal furlon \\
\hline $\begin{array}{l}\text { 10) 269. Tibia tibicen tubicen tuba } \\
\text { [126] }\end{array}$ & & & & 153. tuba traba \\
\hline $\begin{array}{l}\text { 10) 269. Tibia tibicen tubicen tuba } \\
\text { [126] }\end{array}$ & & & & 154. tubicen trabac \\
\hline $\begin{array}{l}\text { 10) 273. Abietis ex abies fit; et ex abies } \\
\text { abiei [127] }\end{array}$ & 529. Abies gyedl & & & 155. Abies yedl \\
\hline $\begin{array}{l}\text { 10) } 275 \text {. A fugio fuga si veniat tibi sit } \\
\text { fugientis [127] }\end{array}$ & & & & 156. fugio vcekam \\
\hline $\begin{array}{l}\text { 10) } 276 \text {. Si fugo sit caput illius solet } \\
\text { esse fugantis [127] }\end{array}$ & & & & 157. fugo gonø \\
\hline $\begin{array}{l}\text { 10) } 281 / 282 \text {. Aerugo sepe tempestas } \\
\text { dicitur esse aeris [127] }\end{array}$ & & 305. eruga rdza & & 158. Arugo pokmura \\
\hline $\begin{array}{l}\text { 10) } 286 \text {. Dicitur alga maris; sed dicitur } \\
\text { alva paludis [127] }\end{array}$ & & 70. alga szytowye & & $\begin{array}{l}\text { 160. Alga trescz } \\
\text { morska }\end{array}$ \\
\hline \multirow[t]{6}{*}{$\begin{array}{l}\text { 10) } 286 \text {. Dicitur alga maris; sed dicitur } \\
\text { alva paludis [127]// 12) } 91 \text {. Stans ex } \\
\text { natura palus est [148] }\end{array}$} & $\begin{array}{l}\text { 25. palus } \\
\text { moczydlo }\end{array}$ & $\begin{array}{l}\text { 642. palus } \\
\text { moczidlo }\end{array}$ & & $\begin{array}{l}\text { 161. palus et stagnum } \\
\text { bagno }\end{array}$ \\
\hline & & 590. minera ruda & & 162. Minera ruda \\
\hline & $\begin{array}{l}\text { 380. Cornix } \\
\text { wrana }\end{array}$ & & 271. ? czeczerza & 163. cornix czeczerza \\
\hline & & & $\begin{array}{l}\text { 79. conturnix } \\
\text { yarząb }\end{array}$ & $\begin{array}{l}\text { 164. Conturnix } \\
\text { yarzøb }\end{array}$ \\
\hline & $\begin{array}{l}\text { 184. Macer } \\
\text { chirawy }\end{array}$ & $\begin{array}{l}\text { 557. macies } \\
\text { chudoscz }\end{array}$ & & 167. Macer chudi \\
\hline & & $\begin{array}{l}\text { 65. attenuatus } \\
\text { vsdrączoni }\end{array}$ & & $\begin{array}{l}\text { 168. attenuatus } \\
\text { precharsli }\end{array}$ \\
\hline $\begin{array}{l}\text { 10) 291. Est antela quod est in pectore } \\
\text { quadrupedantis [129] }\end{array}$ & $\begin{array}{l}\text { 448. Anena } \\
\text { prsosyny }\end{array}$ & $\begin{array}{l}\text { 73. antela } \\
\text { potpyrsznik }\end{array}$ & & 169. antela popersiny \\
\hline \multirow[t]{2}{*}{$\begin{array}{l}\text { 10) } 292 . \text { Dicatur postela quod est } \\
\text { a posteriori [129] }\end{array}$} & $\begin{array}{l}\text { 449. Postema } \\
\text { pochwy }\end{array}$ & & & 170. postela pochwy \\
\hline & $\begin{array}{l}\text { 445. capistrum } \\
\text { ohlaw }\end{array}$ & & & $\begin{array}{l}\text { 172. Capistrum } \\
\text { oglow }\end{array}$ \\
\hline
\end{tabular}




\begin{tabular}{|c|c|c|c|c|}
\hline Graecismus & $\begin{array}{l}\text { Słowniczek } \\
\text { świętowicki }\end{array}$ & $\begin{array}{c}\text { BJ, } \\
\text { rkps } 228\end{array}$ & $\begin{array}{c}\text { Rkps } \\
\text { Lat.I.F.ch.254 }\end{array}$ & $\begin{array}{l}\text { Wokabularz } \\
\text { trydencki }\end{array}$ \\
\hline & $\begin{array}{l}\text { 443. Subsella } \\
\text { podklad }\end{array}$ & & & $\begin{array}{l}\text { 173. Subsella } \\
\text { podclad }\end{array}$ \\
\hline & & $\begin{array}{l}\text { 418. habena } \\
\text { wodze }\end{array}$ & & 174. Abena wodze \\
\hline $\begin{array}{l}\text { 12) } 265 \text {. Est thorax pectus thorax lorica } \\
\text { liquorque [159] }\end{array}$ & & & & 176. lorica pancer \\
\hline \multirow[t]{2}{*}{$\begin{array}{l}\text { 12) } 265 \text {. Est thorax pectus thorax lorica } \\
\text { liquorque [159] }\end{array}$} & & & & 177. Torax latti \\
\hline & & $\begin{array}{l}\text { 644. pectorale } \\
\text { blusbrach }\end{array}$ & & $\begin{array}{l}\text { 178. pectorale } \\
\text { blusprach }\end{array}$ \\
\hline $\begin{array}{l}\text { 10) } 65 . \text { Et tegimen pharetre strigilis } \\
\text { esse solet [113] }\end{array}$ & & & & 180. faretra tul \\
\hline \multirow[t]{2}{*}{$\begin{array}{l}\text { 10) } 66 \text {. Et stantis strigilis currit per } \\
\text { stagmina tele [113] // 11) 14. Dicitur } \\
\text { a iactu iaculum; telum quia longum } \\
{[131]}\end{array}$} & & $\begin{array}{l}800 . \text { telum } \\
\text { brzechwa / } 872 . \\
\text { telum ssyp }\end{array}$ & & 181. telum brechwa \\
\hline & 259. furca wydly & 354. furka vydli & & $\begin{array}{l}\text { 182. biscuspis furca } \\
\text { vidlicza }\end{array}$ \\
\hline $\begin{array}{l}\text { 11) } 15 \text {. Missile nomen habet quia } \\
\text { mittitur impetuose [131] }\end{array}$ & & & & $\begin{array}{l}\text { 183. pixis misile } \\
\text { puska }\end{array}$ \\
\hline $\begin{array}{l}\text { 11) } 16 . \text { Spicla simul pyla generaliter } \\
\text { ista vocantur [131] }\end{array}$ & & & & 184. Spica clossz \\
\hline \multirow[t]{4}{*}{$\begin{array}{l}\text { 11) } 16 . \text { Spicla simul pyla generaliter } \\
\text { ista vocantur [131] }\end{array}$} & 29. pilum gystba & & & 185. pilum $\mathrm{st}<\mathrm{r}>$ ala \\
\hline & & $\begin{array}{l}\text { 760. strofeum } \\
\text { opassanye }\end{array}$ & & $\begin{array}{l}\text { 186. strophium } \\
\text { opasane }\end{array}$ \\
\hline & $\begin{array}{l}\text { 394. hirundo } \\
\text { wlastowyczye }\end{array}$ & & & $\begin{array}{l}\text { 188. Irundo } \\
\text { jastcolicza }\end{array}$ \\
\hline & 361. Nepos wnuk & 604. nepos nyecz & 182. nepos nyecz & 190. Nepos necz \\
\hline $\begin{array}{l}\text { 12) } 226 \text {. Presulis est mitra; sit } \\
\text { nobiliumque thiara [158] }\end{array}$ & & & & $\begin{array}{l}\text { 192. Tyara } \\
\text { yalmunicza }\end{array}$ \\
\hline $\begin{array}{l}\text { 11) 5. Densatum proprie quod fit } \\
\text { densum liquet esse [130] }\end{array}$ & & & & $\begin{array}{l}\text { 193.-194. densetum } \\
\text { gøste uel alio nomine } \\
\text { ganszcze }\end{array}$ \\
\hline \multirow[t]{3}{*}{$\begin{array}{l}\text { 9) } 177 \text {. Virgulti custos homo dicitur } \\
\text { esse viredus [96] }\end{array}$} & & & $\begin{array}{l}\text { 678. virgultum } \\
\text { przath }\end{array}$ & $\begin{array}{l}\text { 195. Virgultum } \\
\text { zapusta }\end{array}$ \\
\hline & $\begin{array}{l}\text { 440. Equirea } \\
\text { swerzepiczye }\end{array}$ & $\begin{array}{l}\text { 297. equirea stado } \\
\text { koni }\end{array}$ & 143. ? stado kony & $\begin{array}{l}\text { 199. Equirea stado } \\
\text { coni }\end{array}$ \\
\hline & & $\begin{array}{l}\text { 357. frutex } \\
\text { latorosl }\end{array}$ & & 205. Frutex latorosl \\
\hline \multirow{4}{*}{$\begin{array}{l}\text { 12) 5. A cubito supra dimensiio dicitur } \\
\text { ulna / 6. Quodque premit cubitus dici } \\
\text { solet esse lacertus / } 7 \text {. He partes gemine } \\
\text { dicuntur brachia iuncte }[135]\end{array}$} & $\begin{array}{l}143 \text {. lacertus } \\
\text { ramye }\end{array}$ & & 353. lacertus bark & 206. lacertus pacha \\
\hline & $\begin{array}{l}\text { 496. Lacerta } \\
\text { gyesterka }\end{array}$ & & $\begin{array}{l}265 . \text { lacerta } \\
\text { yesczerzycza }\end{array}$ & $\begin{array}{l}\text { 207. lacerta } \\
\text { yesczezicza }\end{array}$ \\
\hline & $\begin{array}{l}\text { 10. Fulgur } \\
\text { blyskota }\end{array}$ & $\begin{array}{l}\text { 385. fulmen } \\
\text { gnyef }\end{array}$ & & 209. fulmen porun \\
\hline & & 860. velum opona & & $\begin{array}{l}210 . \text { Velum in } \\
\text { Eclesia }\end{array}$ \\
\hline
\end{tabular}




\begin{tabular}{|c|c|c|c|c|}
\hline Graecismus & $\begin{array}{l}\text { Słowniczek } \\
\text { świętowicki }\end{array}$ & $\begin{array}{c}\text { BJ, } \\
\text { rkps } 228\end{array}$ & $\begin{array}{c}\text { Rkps } \\
\text { Lat.I.F.ch.254 }\end{array}$ & $\begin{array}{l}\text { Wokabularz } \\
\text { trydencki }\end{array}$ \\
\hline $\begin{array}{l}\text { 12) } 4 \text {. Atque perichelides exornant } \\
\text { brachia nimphes [135] }\end{array}$ & & & & $\begin{array}{l}\text { 212. perichelides } \\
\text { sczirki }\end{array}$ \\
\hline 12) 1. Pectoris est proprie spinter [135] & & $\begin{array}{l}\text { 761. spinter } \\
\text { sponka }\end{array}$ & $\begin{array}{l}\text { 316. spinter } \\
\text { sponka }\end{array}$ & 214. Spinter zaponka \\
\hline \multirow[t]{2}{*}{ 12) 1. pariterque monile [135] } & & $\begin{array}{l}\text { 579. monile } \\
\text { sponka }\end{array}$ & & 215. Monile sponka \\
\hline & & 353. fibula stpyen & 573. fibula stpyen & 216. fibula stpen \\
\hline $\begin{array}{l}\text { 10) } 182 . \text { Stirps ambit prosapia; } \\
\text { coniunctique propago [122] }\end{array}$ & & & & 217. Stema propago \\
\hline \multirow[t]{2}{*}{$\begin{array}{l}\text { 12) 203. Stirps de progenie; stirps radix } \\
\text { dicitur esse / 204. Arboribus dabitur hic } \\
\text { stirps; animalibus hec stirps [157] }\end{array}$} & & & & 218. progenies id est \\
\hline & & $\begin{array}{l}\text { 159. cicatrix } \\
\text { blisna }\end{array}$ & $\begin{array}{l}\text { 107. cicatrix paga } \\
\text { blysna }\end{array}$ & $\begin{array}{l}\text { 219. Cikatrix sram } \\
\text { uel rana }\end{array}$ \\
\hline 11) 34. Sunt fastidia tedia [132] & & $\begin{array}{l}\text { 338. fastidium } \\
\text { myerszączka }\end{array}$ & & 220. fastidium tøga \\
\hline \multirow[t]{2}{*}{ 11) 34. Sunt fastidia tedia [132] } & & & & 221. Tedium tesnoscz \\
\hline & & $\begin{array}{l}\text { 337. fastus-tus- } \\
\text { tui pycha }\end{array}$ & & 222. fastus strop \\
\hline $\begin{array}{l}\text { 11) 44. Fercula sunt epule [133] // 11) } \\
\text { 71. Fercula sunt epule farie [134] }\end{array}$ & & & & 223. daps ferculum \\
\hline $\begin{array}{l}\text { 11) 39. Dicitur unguentum quoniam nos } \\
\text { ungimur illo [132] }\end{array}$ & & & & $\begin{array}{l}\text { 226. Unguentum } \\
\text { Mascz }\end{array}$ \\
\hline $\begin{array}{l}\text { 12) 144. Quo latro signatur dic } \\
\text { cauterium fore ferrum [145] }\end{array}$ & & $\begin{array}{l}\text { 157. cauterium } \\
\text { zegadlo }\end{array}$ & & $\begin{array}{l}\text { 229. Cauterium } \\
\text { szegadlo }\end{array}$ \\
\hline $\begin{array}{l}\text { 9) } 308 . \text { Dicatur vates si quicquid } \\
\text { vaticinatur / 309. Sitque propheta tibi } \\
\text { quisquis divina profatur [106] }\end{array}$ & & & & $\begin{array}{l}\text { 230. Vates et } \\
\text { propheta prorok }\end{array}$ \\
\hline $\begin{array}{l}\text { 9) 208. A perpendendo garritus alitis } \\
\text { augur [98] }\end{array}$ & & & & $\begin{array}{l}\text { 231. garitus sczeboth } \\
\text { avium }\end{array}$ \\
\hline \multirow[t]{9}{*}{$\begin{array}{l}\text { 11) } 54 \text {. Dicitur a penu penus quo nutrio } \\
\text { signat [133] }\end{array}$} & $\begin{array}{l}\text { 304. penus } \\
\text { pywnyczna } \\
\text { ssygye }\end{array}$ & $\begin{array}{l}\text { 697. penus } \\
\text { przetpywnicze }\end{array}$ & & $\begin{array}{l}\text { 234. penus piwniczna } \\
\text { sziga }\end{array}$ \\
\hline & 308. lixa sluha & & & 235. lixa sinkazy \\
\hline & & & 194. nutrix doyka & 236. nutrix mama \\
\hline & & & $\begin{array}{l}\text { 195. obstetrix } \\
\text { paporzeza }\end{array}$ & 237. obstitrix baba \\
\hline & & $\begin{array}{l}\text { 185. callis twarda } \\
\text { droga }\end{array}$ & & $\begin{array}{l}\text { 239. strata callis } \\
\text { goscinecz }\end{array}$ \\
\hline & & 620. orbita coleya & 319. orbita coleya & 240 . orbita coleyga \\
\hline & & & $\begin{array}{l}\text { 618. ministerialis } \\
\text { rzadnyk }\end{array}$ & $\begin{array}{l}\text { 241.Ministerialis } \\
\text { sluzebnik }\end{array}$ \\
\hline & & $\begin{array}{l}\text { 154. castellanus } \\
\text { grododzirsza }\end{array}$ & $\begin{array}{l}\text { 201. castellanus } \\
\text { stolecznyk }\end{array}$ & $\begin{array}{l}\text { 243. Castellanus } \\
\text { wogevoda }\end{array}$ \\
\hline & & $\begin{array}{l}\text { 378. famosus } \\
\text { wyekyey falij }\end{array}$ & $\begin{array}{l}\text { 577. famosus } \\
\text { slavythny }\end{array}$ & $\begin{array}{l}\text { 245. famosus } \\
\text { slawøtni }\end{array}$ \\
\hline $\begin{array}{l}\text { 10) 234. Fas neutri generis significat } \\
\text { licitum }[125]\end{array}$ & & & & $\begin{array}{l}\text { 246. licitum phas } \\
\text { podobno }\end{array}$ \\
\hline
\end{tabular}




\begin{tabular}{|c|c|c|c|c|}
\hline Graecismus & $\begin{array}{l}\text { Słowniczek } \\
\text { świętowicki }\end{array}$ & $\begin{array}{l}\text { BJ, } \\
\text { rkps } 228\end{array}$ & $\begin{array}{c}\text { Rkps } \\
\text { Lat.I.F.ch.254 }\end{array}$ & $\begin{array}{l}\text { Wokabularz } \\
\text { trydencki }\end{array}$ \\
\hline & & $\begin{array}{l}\text { 151. celer rączy } \\
\text { vel citus }\end{array}$ & & $\begin{array}{l}\text { 247. velox celer } \\
\text { røczy }\end{array}$ \\
\hline & $\begin{array}{l}\text { 636. Canapum } \\
\text { syemenecz }\end{array}$ & & & 248. canappe konope \\
\hline $\begin{array}{l}\text { 10) 69. Germana est amita patris; } \\
\text { matertera matris [113] }\end{array}$ & $\begin{array}{l}\text { 228. Matertera } \\
\text { materzyna }\end{array}$ & & & 250. Matertera kotka \\
\hline $\begin{array}{l}\text { 9) } 12 \text {. Idrus et anguis aque // } 15 \text {. Idrus } \\
\text { eo qui aquas habitat [86] }\end{array}$ & & & & $\begin{array}{l}\text { 251. Jdrus polni } \\
\text { wosz }\end{array}$ \\
\hline \multirow[t]{3}{*}{$\begin{array}{l}\text { 9) 12. dracho templi // 16. Ast a tracone } \\
\text { tu dicas esse dracones [86] }\end{array}$} & & & & 252. draco smok \\
\hline & & $\begin{array}{l}\text { 95. Bannitum } \\
\text { iudicium }\end{array}$ & & $\begin{array}{l}\text { 253. banitum } \\
\text { judicium gayni søndz }\end{array}$ \\
\hline & & $\begin{array}{l}\text { 210. circum- } \\
\text { spectus rostropnij }\end{array}$ & & $\begin{array}{l}\text { 255. prouidus } \\
\text { circumstepcus opatrni }\end{array}$ \\
\hline \multirow[t]{2}{*}{$\begin{array}{l}\text { 9) 299. Aera dic nostrum sed dicas } \\
\text { ethera sursum [105] }\end{array}$} & $\begin{array}{l}\text { 206. Aer } \\
\text { powyetrzye }\end{array}$ & & & 257. Aer poetze \\
\hline & & 19. agger grobla & & 259. agger grobla \\
\hline \multirow[t]{2}{*}{$\begin{array}{l}\text { 10) } 21 . \text { De puro calibe cassida dic } \\
\text { proprie }[110]\end{array}$} & & & 61. ? stal & 264. Callis stal \\
\hline & & & $\begin{array}{l}\text { 63. cuprum } \\
\text { moszyacz }\end{array}$ & 265. Cuprus medz \\
\hline $\begin{array}{l}\text { 11) } 69 . \text { Materiam gracilem murorum } \\
\text { menia dicas }[134]\end{array}$ & & & & 266. menia czena \\
\hline \multirow[t]{2}{*}{$\begin{array}{l}\text { 11) } 70 \text {. Ast intersticia sunt propugnacula } \\
\text { dicta [134] }\end{array}$} & & & $\begin{array}{l}\text { 629. propugna- } \\
\text { culum strelnycza }\end{array}$ & $\begin{array}{l}\text { 267. propugnaculum } \\
\text { colowrotni }\end{array}$ \\
\hline & $\begin{array}{l}\text { 573. palmes } \\
\text { ratorasly }\end{array}$ & & & 269. palmes latorosl \\
\hline \multirow[t]{7}{*}{ 12) 45. libitum libitine [138] } & & $\begin{array}{l}\text { 509. libitina maris } \\
\text { i.e. feretris }\end{array}$ & & 271. libitima mary \\
\hline & & 160. coma grziwa & $\begin{array}{l}\text { 476. coma stryk } \\
\text { grzywa }\end{array}$ & 273. Coma grrzywa \\
\hline & & & 349. ? czema & 274. Interciput czemø \\
\hline & 68. Occiput tyl & & & 275. Occiput til \\
\hline & $\begin{array}{l}\text { 72. Cerebellum } \\
\text { leb }\end{array}$ & & & $\begin{array}{l}\text { 276. Cerebellum } \\
\text { plecz }\end{array}$ \\
\hline & & $\begin{array}{l}\text { 582. mandibula } \\
\text { czeluscz }\end{array}$ & $\begin{array}{l}\text { 337. mandibula } \\
\text { czeluscz }\end{array}$ & $\begin{array}{l}\text { 278. } \mathrm{Ma}<\mathrm{n}>\text { dibula } \\
\text { celuscz }\end{array}$ \\
\hline & $\begin{array}{l}\text { 164. Stomachus } \\
\text { zeludek / } 147 . \\
\text { vmbilicus pupek }\end{array}$ & & & $\begin{array}{l}\text { 280. Vmbilicus } \\
\text { stomachus idem sunt }\end{array}$ \\
\hline $\begin{array}{l}\text { 12) } 258 \text {. Continet untrunque seu dicunt } \\
\text { tibia crus [158] }\end{array}$ & 152. Crus stehno & & 347. crus vd & 281. Crus vd \\
\hline \multirow[t]{2}{*}{$\begin{array}{l}\text { 12) 257. Sura genus ceptum sed sure } \\
\text { est in pede finis [158] }\end{array}$} & 154. Sura lytka & & 348. sura lysth & 282. Szura litky \\
\hline & 148. Clunes bedry & & & 283. Clunis bodra \\
\hline \multirow[t]{2}{*}{$\begin{array}{l}\text { 12) } 256 \text {. Meta genus femoris sed ducit } \\
\text { ab inguine ceptum }[158]\end{array}$} & & & 345. ? ląndzwye & 284. femur ladwa \\
\hline & $\begin{array}{l}\text { 77. palpebra } \\
\text { wyeczcze }\end{array}$ & & & $\begin{array}{l}\text { 285. palpebra } \\
\text { poweka }\end{array}$ \\
\hline
\end{tabular}




\begin{tabular}{|c|c|c|c|c|}
\hline \multirow[t]{8}{*}{ Graecismus } & $\begin{array}{l}\text { Słowniczek } \\
\text { świętowicki }\end{array}$ & $\begin{array}{c}\text { BJ, } \\
\text { rkps } 228\end{array}$ & $\begin{array}{c}\text { Rkps } \\
\text { Lat.I.F.ch.254 }\end{array}$ & $\begin{array}{l}\text { Wokabularz } \\
\text { trydencki }\end{array}$ \\
\hline & $\begin{array}{l}\text { 572. vitis wynny } \\
\text { korzen }\end{array}$ & & & 287. Vitis maczicza \\
\hline & $\begin{array}{l}577 . \text { Botrus } \\
\text { hrozen }\end{array}$ & & & $\begin{array}{l}\text { 288. botrum grono } \\
\text { vini }\end{array}$ \\
\hline & 578. uva yahoda & & & 289. Vva yagoda \\
\hline & & 81. aspergus ricz & $\begin{array}{l}\text { 534. aspergus } \\
\text { rzydz }\end{array}$ & 293. Aspergus ridz \\
\hline & $\begin{array}{l}\text { 326. presepe } \\
\text { gyesly }\end{array}$ & & & $\begin{array}{l}\text { 296. mandrum } \\
\text { presepe iasli }\end{array}$ \\
\hline & 417. luter wydra & 546. luter vydra & & 303. luter widra \\
\hline & $\begin{array}{l}\text { 620. Stramen } \\
\text { Slama }\end{array}$ & & & 304. strumen krantan \\
\hline $\begin{array}{l}\text { 11) } 36 \text {. De re iocunda metrice sunt } \\
\text { carmina dicta / } 37 \text {. Dictamen prosa est } \\
\text { a metri lege solutum / } 38 \text {. Carmen certa } \\
\text { pedum dimensio sit tibi metrum [132] }\end{array}$ & & & & 309. Carmen pismo \\
\hline \multirow[t]{2}{*}{$\begin{array}{l}\text { 10) } 78 / 80 \text {. [Vitta] per duo t scriptum } \\
\text { muliebre notat redimiclum [114] }\end{array}$} & & & & $\begin{array}{l}\text { 310.-311. Witta } \\
\text { zawoy uel podwika } \\
\text { in muliere }\end{array}$ \\
\hline & $\begin{array}{l}\text { 66. Tempus } \\
\text { tyeme }\end{array}$ & & $\begin{array}{l}\text { 351. tempus } \\
\text { schronya }\end{array}$ & 312. Timpus scrona \\
\hline \multirow[t]{6}{*}{$\begin{array}{l}\text { 10) } 78 / 80 \text {. [Vitta] per duo t scriptum } \\
\text { muliebre notat redimiclum [114] }\end{array}$} & & & & $\begin{array}{l}\text { 313.-314. Redimi- } \\
\text { culum sloyerz uel } \\
\text { alio nomine Cranecz }\end{array}$ \\
\hline & & & $\begin{array}{l}\text { 611. mergus } \\
\text { norek }\end{array}$ & 315. Mergus norecz \\
\hline & & & 229. ? bethnarz & $\begin{array}{l}\text { 316. doleator } \\
\text { bednarzy }\end{array}$ \\
\hline & 584. Iuger gytro & & & 323. Juger wreczen \\
\hline & & & $\begin{array}{l}\text { 659. tugurium } \\
\text { yatha }\end{array}$ & 325. Tugerrium yatka \\
\hline & & $\begin{array}{l}\text { 642. palus } \\
\text { moczidlo }\end{array}$ & & $\begin{array}{l}\text { 334. Stagnum } \\
\text { moczidlo. }\end{array}$ \\
\hline \multirow{3}{*}{$\begin{array}{l}\text { 12) } 79 . \text { Ex usu portus acus et lacus et } \\
\text { tribus inde / } 80 \text {. Ante bus u teneant arc } \\
\text { art part ex ratione [147] }\end{array}$} & 24. Lacus gyezero & & & 335. lacus yesoro \\
\hline & & 170. cauma zagef & & 337. Cauma zagew \\
\hline & 9. Tonitrus hrom & & & 340. Tonitrus grom \\
\hline \multirow[t]{7}{*}{$\begin{array}{l}\text { 12) } 38 \text {. A tumulo tumulum dic a moneo } \\
\text { monumentum [138] }\end{array}$} & & & & $\begin{array}{l}\text { 342. Monumentum } \\
\text { mogila }\end{array}$ \\
\hline & 321. Examen Roy & & & 343. examen badane \\
\hline & & $\begin{array}{l}\text { 641. pabulum } \\
\text { pocarm }\end{array}$ & & 349. pabulum carma \\
\hline & & $\begin{array}{l}\text { 201. crepusculum } \\
\text { mrok }\end{array}$ & & $\begin{array}{l}\text { 353. Crepusculum } \\
\text { mrok }\end{array}$ \\
\hline & & $\begin{array}{l}\text { 158. conticinium } \\
\text { pyrzswospy }\end{array}$ & & $\begin{array}{l}\text { 354. Conticinium } \\
\text { prziswi }\end{array}$ \\
\hline & & 34. aurora rzoza & & 355. Aurora zaza \\
\hline & $\begin{array}{l}\text { 329. Scrinium } \\
\text { schrzynye }\end{array}$ & & & 356. scrinium sczina \\
\hline
\end{tabular}




\begin{tabular}{|c|c|c|c|c|}
\hline Graecismus & $\begin{array}{l}\text { Słowniczek } \\
\text { świętowicki }\end{array}$ & $\begin{array}{l}\text { BJ, } \\
\text { rkps } 228\end{array}$ & $\begin{array}{l}\text { Rkps } \\
\text { Lat.I.F.ch.254 }\end{array}$ & $\begin{array}{l}\text { Wokabularz } \\
\text { trydencki }\end{array}$ \\
\hline $\begin{array}{l}\text { 10) 39. Auxilitum designat opis; sed } \\
\text { opes notat gaze [111] }\end{array}$ & & & & 357. gasa skarb \\
\hline $\begin{array}{l}\text { 10) 141. Insula sit maris; at si dulcis } \\
\text { aque mediamnis / } 142 \text {. Insula cincta } \\
\text { salo; mediamnen circuit amnis [118] }\end{array}$ & & & & $\begin{array}{l}\text { 365. Media }<\text { m }>\text { nis } \\
\text { wisep }\end{array}$ \\
\hline \multirow[t]{11}{*}{$\begin{array}{l}\text { 12) } 162 \text {. Torrens est quoniam voluitur } \\
\text { absque modo [153] }\end{array}$} & & $\begin{array}{l}\text { 804. torrens } \\
\text { struga }\end{array}$ & & 366. Torrens prød \\
\hline & 122. vber wyme & & & 368. Vber vyme \\
\hline & & 820. vber chudi & & 369. Vber plodni \\
\hline & $\begin{array}{l}\text { 123. Mamma } \\
\text { czekczky }\end{array}$ & & & $\begin{array}{l}\text { 370. Mamma apud } \\
\text { mulierem }\end{array}$ \\
\hline & & $\begin{array}{l}\text { 757. sterilis } \\
\text { yalowij }\end{array}$ & & 371. sterilis yalowy \\
\hline & & $\begin{array}{l}\text { 503. lasciuus } \\
\text { nyeczisti }\end{array}$ & & 372. lasciuus yary \\
\hline & & 160. coma grziwa & $\begin{array}{l}\text { 476. coma stryk } \\
\text { grzywa }\end{array}$ & 375. Coma grziwa \\
\hline & & 513. limes prog & & 377. limes medza \\
\hline & $\begin{array}{l}\text { 186. Adolescens } \\
\text { gynoch }\end{array}$ & & & $\begin{array}{l}\text { 379. Adolescens } \\
\text { podrosni }\end{array}$ \\
\hline & 547. laurus bobek & & & $\begin{array}{l}383-384 \text {. laurus est } \\
\text { arbor lauribaca bobek }\end{array}$ \\
\hline & $\begin{array}{l}\text { 561. Bombyx } \\
\text { bawlna }\end{array}$ & & & $\begin{array}{l}\text { 391. bombex dicitur } \\
\text { vermiculus }\end{array}$ \\
\hline \multirow[t]{3}{*}{$\begin{array}{l}\text { 10) 232. Pistricem monstrum suspicor } \\
\text { esse maris [125] }\end{array}$} & & & & $\begin{array}{l}\text { 394. Spinx monstrum } \\
\text { marinum }\end{array}$ \\
\hline & & & $\begin{array}{l}\text { 230. ? tluscza } \\
\text { tlum }\end{array}$ & 403. Choors tluscza \\
\hline & $\begin{array}{l}\text { 267. betha } \\
\text { hlawatyczye }\end{array}$ & & 47. betha czwykla & 408. beta odrosly \\
\hline \multirow[t]{3}{*}{$\begin{array}{l}\text { 9) } 25 \text {. Est nati stirps mascla nepos est } \\
\text { luxuriosus [86] // 10) 182. Stirps ambit } \\
\text { prosapia [122] // 12) 203. Stirps de } \\
\text { progenie; stirps radix dicitur esse / } 204 . \\
\text { Arboribus dabitur hic stirps; animalibus } \\
\text { hec stirps [157] }\end{array}$} & & & & 413. Stirps coszene \\
\hline & & $\begin{array}{l}\text { 290. exul } \\
\text { wygnanyecz }\end{array}$ & $\begin{array}{l}\text { 135. exul } \\
\text { wypovyedzony }\end{array}$ & $\begin{array}{l}\text { 414. exul } \\
\text { wipowedzani }\end{array}$ \\
\hline & & $\begin{array}{l}\text { 159. cicatrix } \\
\text { blisna }\end{array}$ & & 415. Cycastrix sram \\
\hline \multirow[t]{3}{*}{$\begin{array}{l}\text { 10) 194. Quo candela latet tibi sit locus } \\
\text { ille laterna [122] }\end{array}$} & & & & 425. Candela lumen \\
\hline & 41. petra opoka & & & $\begin{array}{l}\text { 426. petra Saxum } \\
\text { scala }\end{array}$ \\
\hline & $\begin{array}{l}\text { 403. Nocticorax } \\
\text { lelek }\end{array}$ & & & 429. nocticorax lelek \\
\hline $\begin{array}{l}\text { 9) } 56 \text {. Est bufo vermis; nomen buboque } \\
\text { volucris / } 57 \text {. Bufo pede graditur; bubo } \\
\text { per alta volat [ } 88]\end{array}$ & 497. Buffo zaba & & 266. buffo zolwy & 430. buffo solw \\
\hline
\end{tabular}




\begin{tabular}{|c|c|c|c|c|}
\hline Graecismus & $\begin{array}{l}\text { Słowniczek } \\
\text { świętowicki }\end{array}$ & $\begin{array}{c}\text { BJ, } \\
\text { rkps } 228\end{array}$ & $\begin{array}{c}\text { Rkps } \\
\text { Lat.I.F.ch.254 }\end{array}$ & $\begin{array}{l}\text { Wokabularz } \\
\text { trydencki }\end{array}$ \\
\hline & & $\begin{array}{l}\text { 762. scutum } \\
\text { tarcza }\end{array}$ & & 433. Scutum tarcza \\
\hline & & $\begin{array}{l}\text { 854. torques } \\
\text { potbrodek }\end{array}$ & & 434. Torques colnerz \\
\hline & & & 352. ? pleczy & 435. Armus plecze \\
\hline $\begin{array}{l}\text { 10) 164. Palma manus; palma est arbor; } \\
\text { victoria palma [120]// 12) 12. Palma } \\
\text { notat laudem [135] }\end{array}$ & & & & 436. palma bagnød \\
\hline $\begin{array}{l}\text { 12) } 17 \text {. Sal neutri generis condimentum } \\
\text { notat oris [136] }\end{array}$ & & & & $\begin{array}{l}\text { 437. Condimentum } \\
\text { vcrasene }\end{array}$ \\
\hline $\begin{array}{l}\text { 12) } 18 \text {. Hic sal si dicas id quod } \\
\text { sapientia signat [136] }\end{array}$ & & & & $\begin{array}{l}\text { 438. sal significat } \\
\text { sapientiam } 2 \text {-modo } \\
\text { etc. }\end{array}$ \\
\hline $\begin{array}{l}\text { 9) } 229 \text {. Fornix est arcus; fornixque } \\
\text { domus meretricis }[100] \text {; 12) } 22 \text {. Fornix } \\
\text { lenonis locus est pariter meretricis [136] }\end{array}$ & & & & $\begin{array}{l}\text { 439. fornix domus } \\
\text { meretricis }\end{array}$ \\
\hline \multirow[t]{17}{*}{$\begin{array}{l}\text { 12) 26. Est usura suos cum quis tradit } \\
\text { mihi numos / } 27 \text {. Spe lucri fenus duplex } \\
\text { usura vocatur [136] }\end{array}$} & & & & $\begin{array}{l}\text { 441. fenus est dux } \\
\text { vsura }\end{array}$ \\
\hline & & $\begin{array}{l}\text { 36. arbutum } \\
\text { lessne yaplko }\end{array}$ & & 445. arbutus chrost \\
\hline & & & $\begin{array}{l}\text { 57. campaster } \\
\text { polnycza }\end{array}$ & $\begin{array}{l}\text { 447. Campestre } \\
\text { polnicza }\end{array}$ \\
\hline & & $\begin{array}{l}\text { 151. celer rączy } \\
\text { vel citus }\end{array}$ & & 448. celer røczy \\
\hline & & $\begin{array}{l}\text { 693. profugus } \\
\text { sbyeg }\end{array}$ & & 452. profugus sbeg \\
\hline & & 818. vadum prod & & 458. Vadum brod \\
\hline & & $\begin{array}{l}\text { 609. nausea } \\
\text { brzitkoscz }\end{array}$ & & 459. nauseo tszimsø \\
\hline & $\begin{array}{l}\text { 628. pisena } \\
\text { hrachowyny }\end{array}$ & & & $\begin{array}{l}\text { 462. pisinum } \\
\text { grochovini }\end{array}$ \\
\hline & & 576. modium spąt & & 464. Modius spød \\
\hline & 13. gelu mraz & & & $\begin{array}{l}\text { 466. frecella gellutrix } \\
\text { gruda }\end{array}$ \\
\hline & $\begin{array}{l}239 . \\
\text { Architriclinus } \\
\text { stari swat }\end{array}$ & & $\begin{array}{l}\text { 193. architriclinus } \\
\text { zyrzec }\end{array}$ & $\begin{array}{l}\text { 467. Architriclunus } \\
\text { zircza }\end{array}$ \\
\hline & & & 280. ? yeszyotr & 469. Esox yasotr \\
\hline & 507. Salmo lossos & 790. salmo lossos & 277. ? loszoszy & 470. Salmo lososs \\
\hline & $\begin{array}{l}\text { 310. flebotomus } \\
\text { pustadlo }\end{array}$ & & & $\begin{array}{l}\text { 471. flebatamus } \\
\text { pusczadlo }\end{array}$ \\
\hline & $\begin{array}{l}589 . \text { Colonus } \\
\text { ratay }\end{array}$ & $\begin{array}{l}176 . \text { colonus } \\
\text { ratay }\end{array}$ & & 472. Colonus ratay \\
\hline & & $\begin{array}{l}\text { 655. peremtorius } \\
\text { dies uel terminus } \\
\text { zawyti rog }\end{array}$ & & $\begin{array}{l}\text { 475. Terminus } \\
\text { concitatus zavestisti } \\
\text { rok }\end{array}$ \\
\hline & & & 199. comes groff & 477. Comes graba \\
\hline
\end{tabular}




\begin{tabular}{|c|c|c|c|c|}
\hline Graecismus & $\begin{array}{l}\text { Słowniczek } \\
\text { świętowicki }\end{array}$ & $\begin{array}{c}\text { BJ, } \\
\text { rkps } 228\end{array}$ & $\begin{array}{c}\text { Rkps } \\
\text { Lat.I.F.ch.254 }\end{array}$ & $\begin{array}{l}\text { Wokabularz } \\
\text { trydencki }\end{array}$ \\
\hline & $\begin{array}{l}\text { 344. Senascalus } \\
\text { Marssalek }\end{array}$ & $\begin{array}{l}\text { 736. senascalus } \\
\text { marszalek }\end{array}$ & & $\begin{array}{l}\text { 478. Senascallus } \\
\text { marsalek }\end{array}$ \\
\hline & & $\begin{array}{l}\text { 472. iusticiarius } \\
\text { oprawcza }\end{array}$ & & $\begin{array}{l}\text { 480. Justiciarius } \\
\text { oprawcza }\end{array}$ \\
\hline \multirow[t]{3}{*}{$\begin{array}{l}\text { 10) 199. Si proprie attendas parva est } \\
\text { virguncula virgo / 200. illibata viro } \\
\text { virgo est; matrona virago [123] }\end{array}$} & & & $\begin{array}{l}\text { 197. virago } \\
\text { mazathka }\end{array}$ & $\begin{array}{l}\text { 481. Virago } \\
\text { møsrzatka }\end{array}$ \\
\hline & & $\begin{array}{l}\text { 287. explorator } \\
\text { laząka }\end{array}$ & $\begin{array}{l}\text { 697. explorator } \\
\text { laząka }\end{array}$ & $\begin{array}{l}\text { 482. Explorator } \\
\text { lasøka }\end{array}$ \\
\hline & $\begin{array}{l}\text { 238. procus } \\
\text { dyewosnub }\end{array}$ & $\begin{array}{l}\text { 662. procus } \\
\text { frigerz }\end{array}$ & $\begin{array}{l}\text { 192. procus } \\
\text { dzewoslab }\end{array}$ & $\begin{array}{l}\text { 483. prochus } \\
\text { dzewosløb }\end{array}$ \\
\hline $\begin{array}{l}\text { 12) } 210 \text {. Ac uxor nati dicitur esse nurus } \\
\text { [157] }\end{array}$ & $\begin{array}{l}249 . \text { Nurus } \\
\text { newyesta }\end{array}$ & 603. nurus yatrew & $\begin{array}{l}\text { 186. nurus } \\
\text { nyewyastka }\end{array}$ & 486. nurus nevasta \\
\hline $\begin{array}{l}\text { 9) 48. Levir nam levum se notat esse } \\
\text { virum [88] // 12) 91. levir de fratre } \\
\text { mariti / 92. dicitur; hic levum quod } \\
\text { notat esse virum [141] }\end{array}$ & & $\begin{array}{l}\text { 545. leuir } \\
\text { dzyewyerz }\end{array}$ & 184. ? dzevyerz & 487. leuir dzewerz \\
\hline \multirow{9}{*}{$\begin{array}{l}\text { 10) } 70 \text {. Estque socrus maior; nurus } \\
\text { altera; fratria glos est [113] // 12) } 90 \text {. } \\
\text { Ille sororius est cui nupta soror mea; } \\
\text { glos est / } 91 \text {. quem frater duxit [141] }\end{array}$} & & 404. glos yątri & & 488. glos yøtry \\
\hline & & & $\begin{array}{l}\text { 191. noverca } \\
\text { mama maczecha }\end{array}$ & 489. vicerta maka \\
\hline & $\begin{array}{l}\text { 211. privignus } \\
\text { pastorek }\end{array}$ & & 187. ? paszyrb & 490. privignus pasirb \\
\hline & $\begin{array}{l}\text { 281. Tegula } \\
\text { przykrywka }\end{array}$ & & & 492. tegula lata \\
\hline & & $\begin{array}{l}\text { 809. tractula } \\
\text { grzeblo }\end{array}$ & & 494. tractura pocask \\
\hline & $\begin{array}{l}\text { 290. Caminus } \\
\text { komyn }\end{array}$ & & & 495. caminus comin \\
\hline & & & $\begin{array}{l}\text { 41. brasorium } \\
\text { slodownya }\end{array}$ & $\begin{array}{l}\text { 498. brasotarium } \\
\text { slodowna }\end{array}$ \\
\hline & & & 42. ? browar & $\begin{array}{l}\text { 499. braxatorium } \\
\text { brovar }\end{array}$ \\
\hline & & $\begin{array}{l}\text { 865. clepsedra } \\
\text { nalefka }\end{array}$ & 58. clepsidra lygy & 505. clepsedra lyg \\
\hline \multirow[t]{5}{*}{$\begin{array}{l}\text { 10) 62. Purgat equum strigilis; strigilis } \\
\text { quoque ferrea cratis [113] }\end{array}$} & & & & 506. strigillis greblo \\
\hline & $\begin{array}{l}\text { 614. Tribula } \\
\text { czyep }\end{array}$ & & & 507. tribula czepi \\
\hline & & $\begin{array}{l}\text { 753. salforium } \\
\text { solnycza }\end{array}$ & & $\begin{array}{l}\text { 508. sal<i>num } \\
\text { solnicza }\end{array}$ \\
\hline & & $\begin{array}{l}85 . \text { asseda } \\
\text { colyepka }\end{array}$ & & 509. assega colebka \\
\hline & 606. Biga kary & $\begin{array}{l}\text { 104. biga gedno } \\
\text { kole }\end{array}$ & & $\begin{array}{l}\text { 510. biga rotum } \\
\text { presentat }\end{array}$ \\
\hline
\end{tabular}


Tabela 2. Sposoby uporządkowania haseł w wokabularzu trydenckim

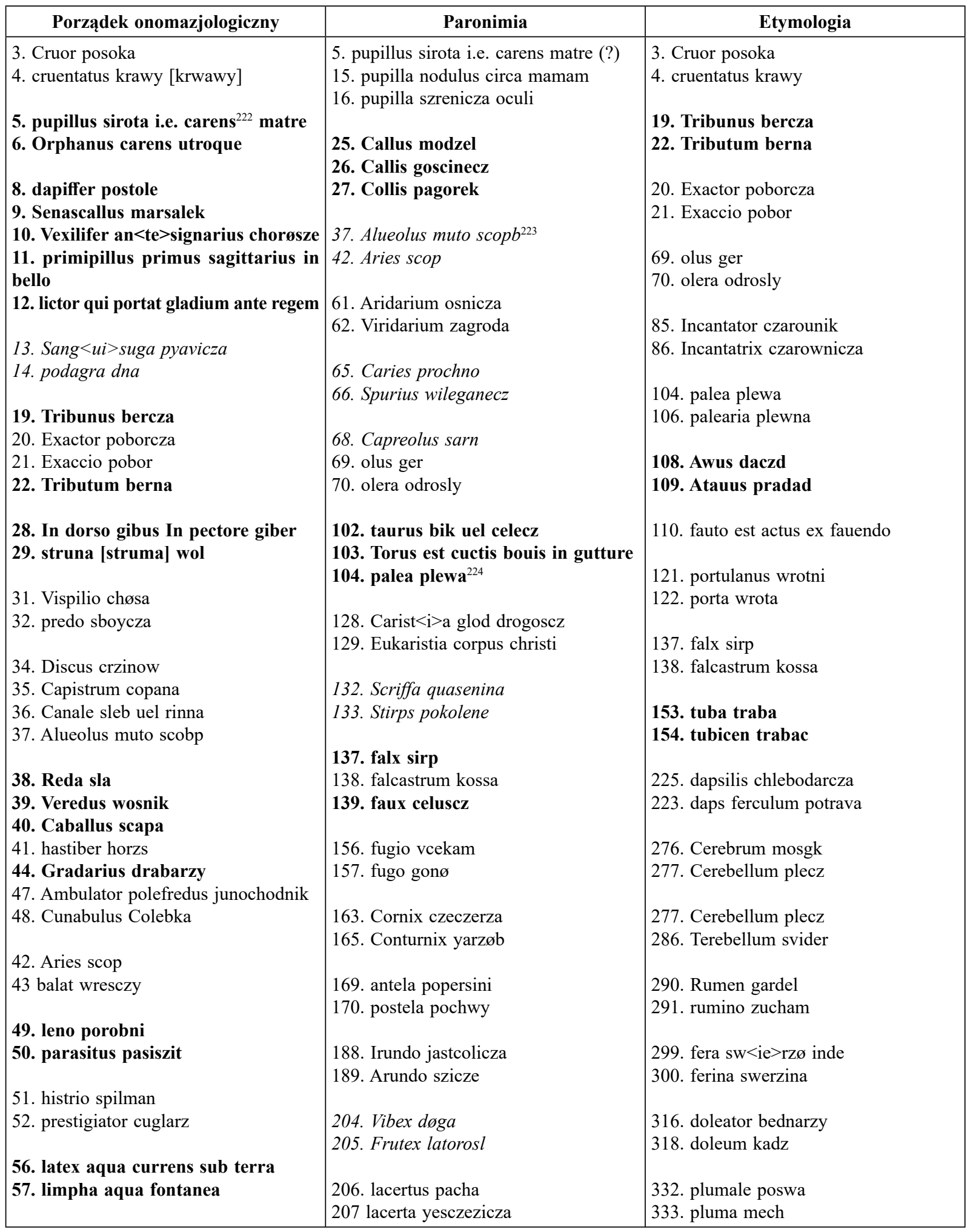

${ }^{222}$ Pogrubieniem oznaczono zestawienia, które pojawiają się w Graecismusie Eberharda z Béthune.

${ }^{223}$ Kursywą oznaczono powiązania niepewne.

${ }^{224}$ Hasła te występują w wokabularzu trydenckim w takiej kolejności ze względu na powiązania paronimiczne w Graecismusie Eberharda z Béthune - zob. tab. 1. 


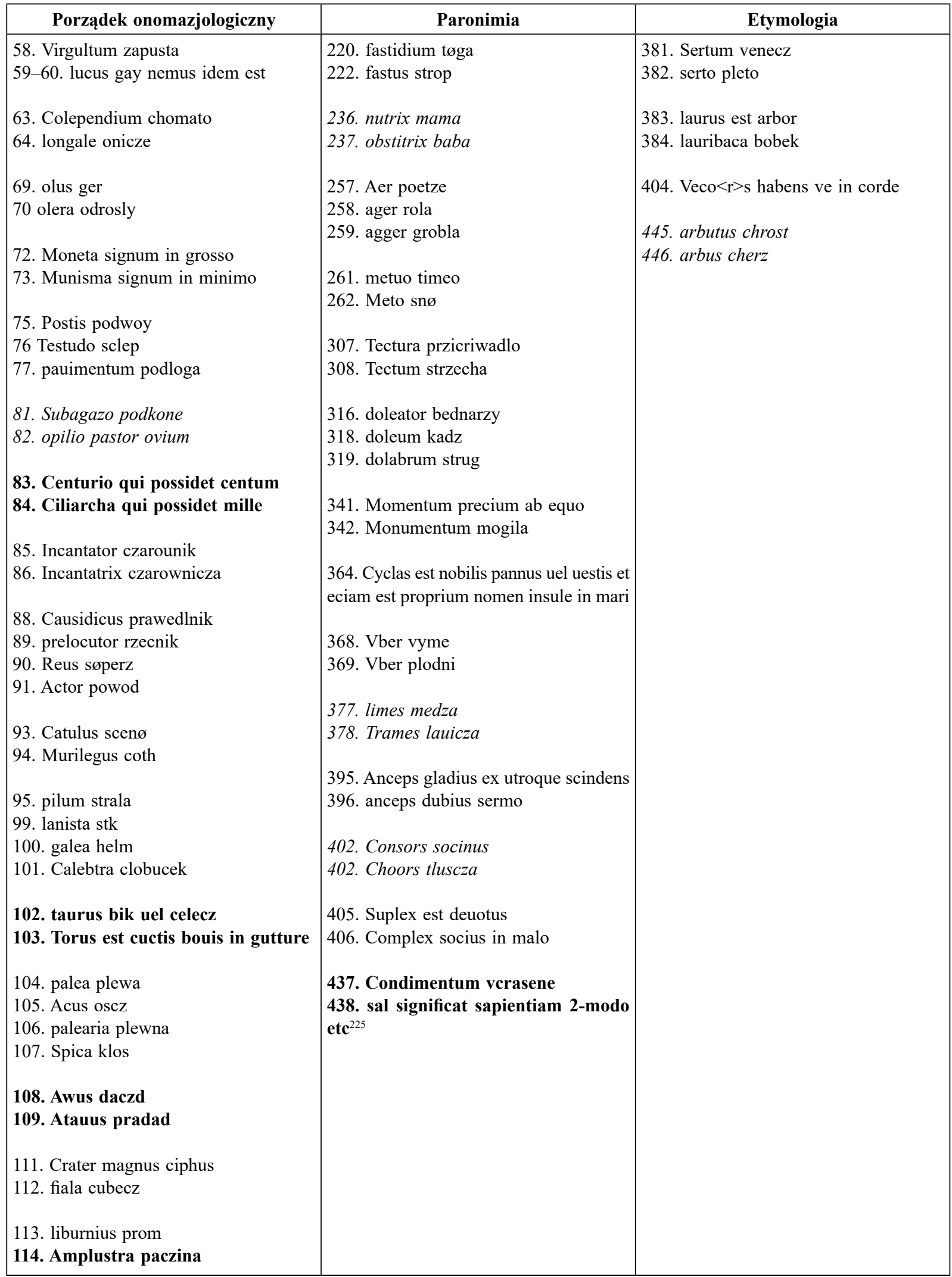

${ }^{225}$ Hasła te występują w wokabularzu trydenckim w takiej kolejności ze względu na powiązania paronimiczne w Graecismusie Eberharda z Béthune - zob. tab. 1 . 


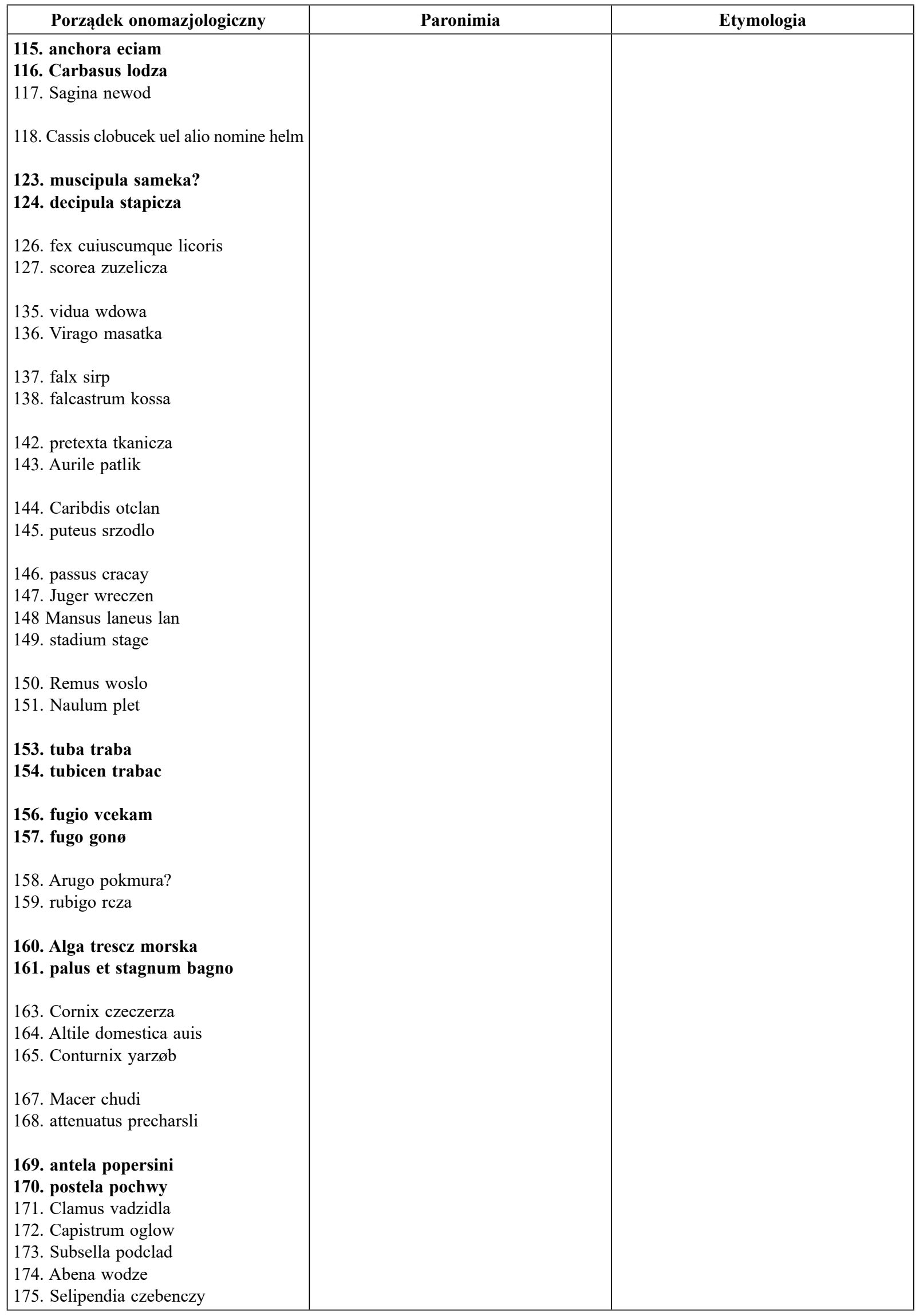




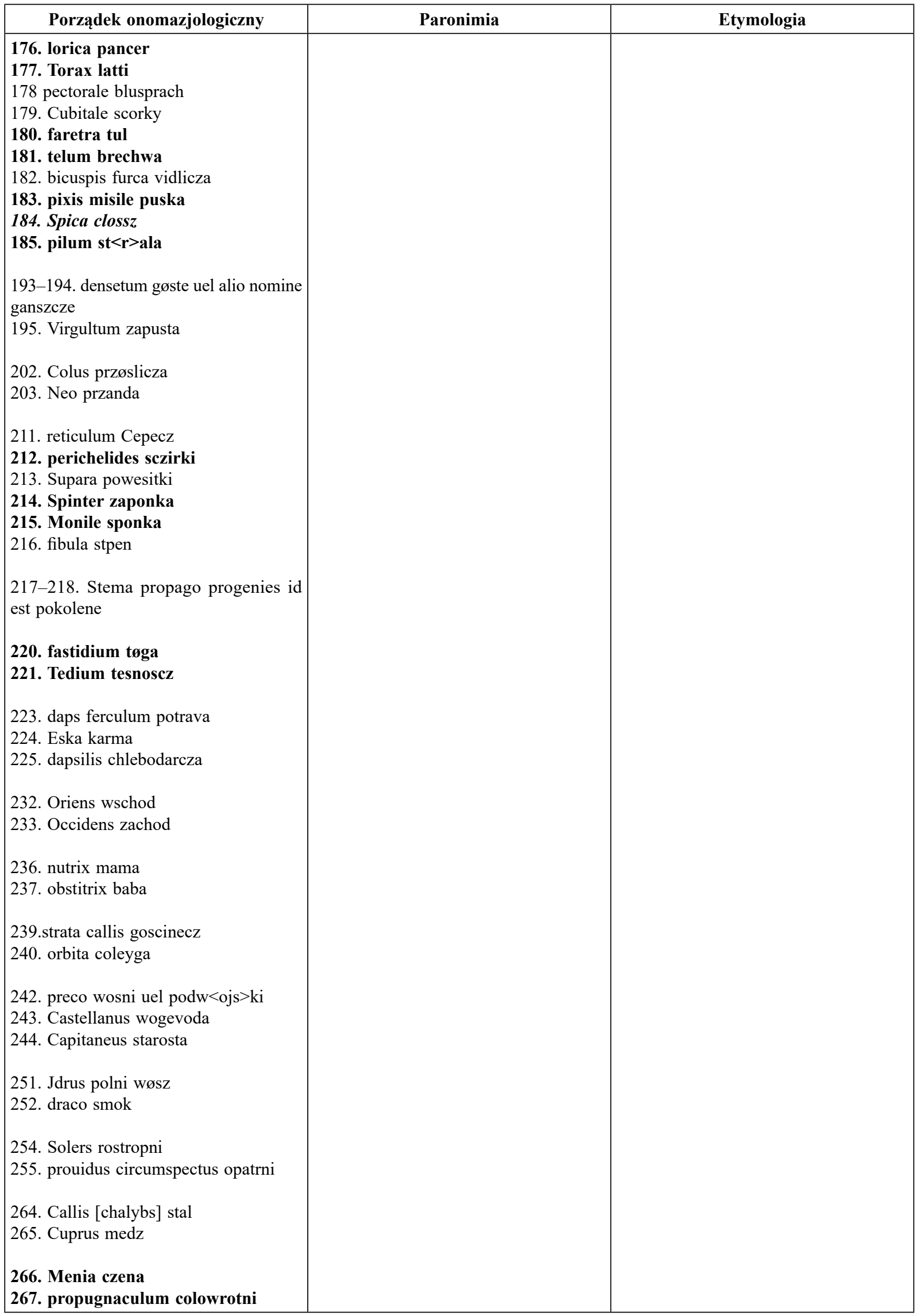




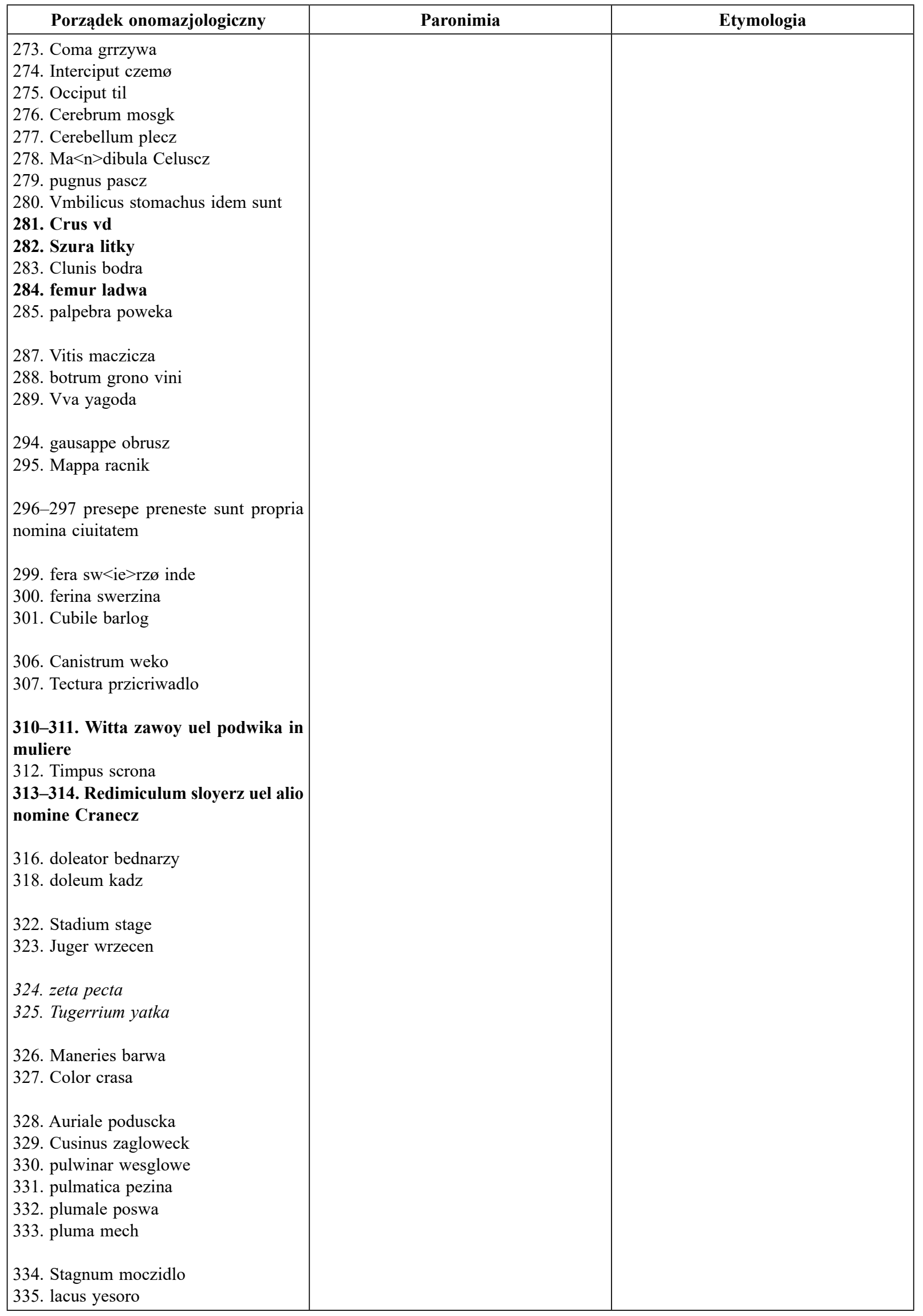




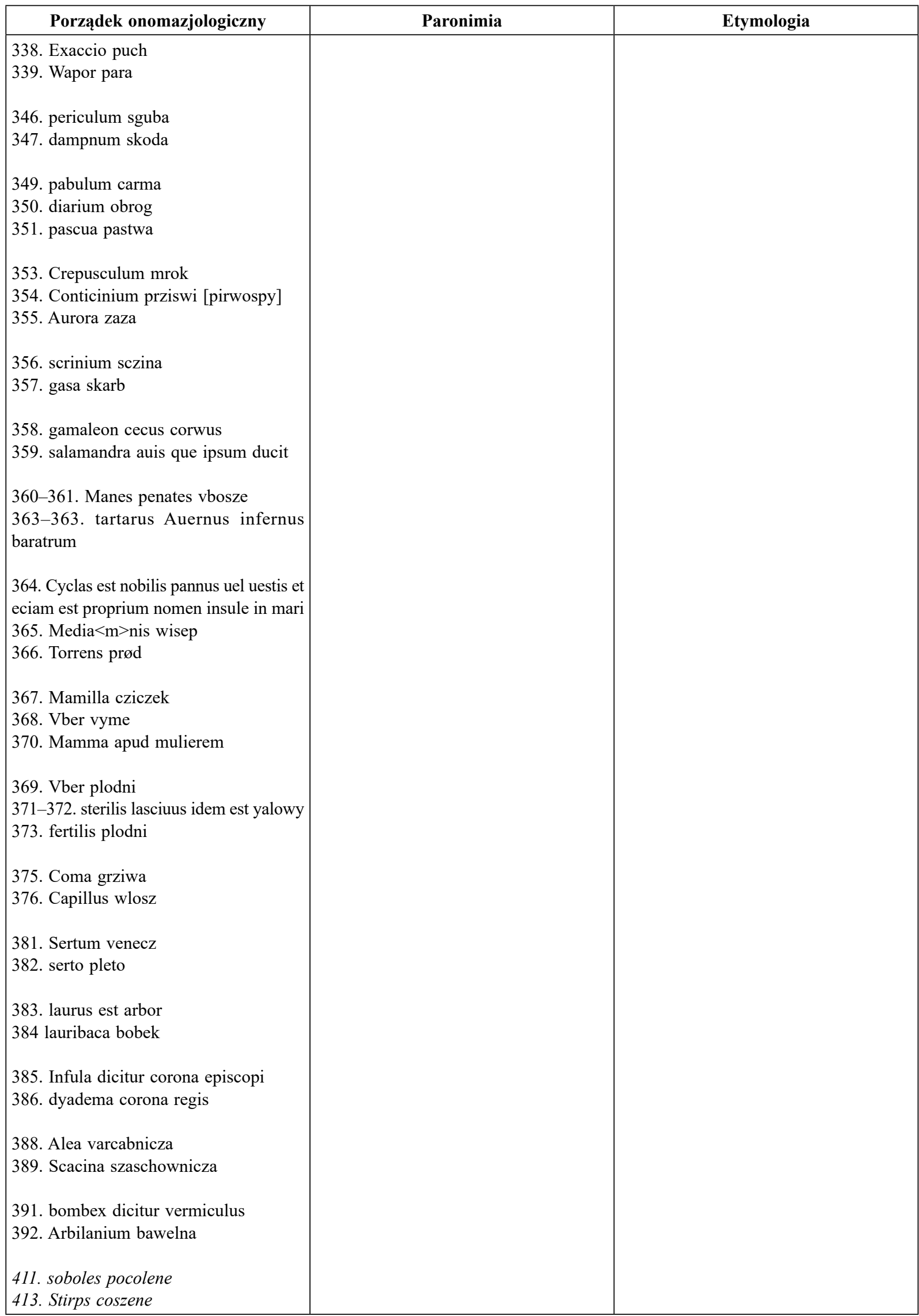




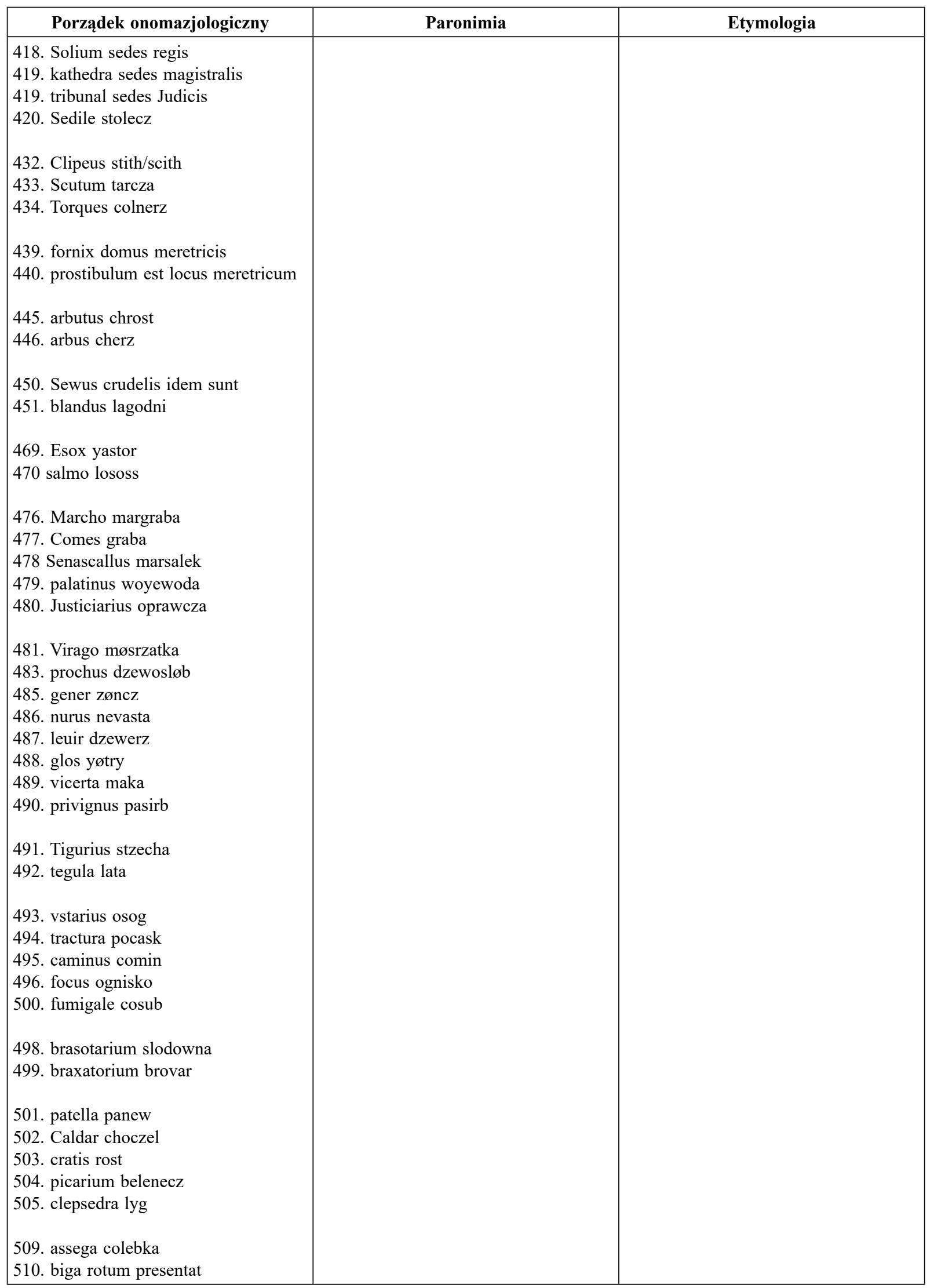




\section{The Vocabulary of Trento as an example of medieval lexicography}

Summary: The article presents a multi-aspect analysis of the vocabulary of Trento, the oldest known Polish-Latin dictionary (c. 1424), in the context of the European medieval lexicography. The aim of the paper is to determine the vocabulary's nature and function. Its content and macrostructure are analysed and compared to the entire formulary of Trento (Cathedral Chapter Archives in Trento, MS 114), in which it was written, as well as to Graecismus by Eberhard of Béthune, and to the three dictionaries from the same period and with a similar structure. A conclusion could be drawn regarding the vocabulary's sources and origin. On the basis of these findings, it was possible to define it as a multidomain dictionary with a didactic aim, created probably in Kraków's university circles. It may have been initially unrelated to the formulary of Trento. The article questions the claim made in the existing literature, according to which the vocabulary was copied or even created especially for Alexander, the prince of Mazovia and bishop of Trento in 1424-1444.

Nota o autorze: Barbara Kaczyńska, absolwentka lingwistyki stosowanej i historii, thumaczka literatury popularnonaukowej, doktorantka na Wydziale Lingwistyki Stosowanej Uniwersytetu Warszawskiego. W swoich badaniach obecnie koncentruje się na recepcji francuskiej baśni literackiej w polskiej literaturze dziecięcej.

Author: Barbara Kaczyńska, MA in applied linguistics and history (specialisation: medieval history), translator of general audience history books, $\mathrm{PhD}$ student in the Department of Applied Linguistics at the University of Warsaw. Her research currently focuses on the reception of French literary fairy tale in Polish children's literature.

Wydział Lingwistyki Stosowanej Uniwersytetu Warszawskiego

ul. Szturmowa 4

02-678 Warszawa

e-mail: b.kaczynska@uw.edu.pl

\section{Bibliografia}

\section{Źródła}

Due testi cechi scoperti da E. Winkler nell'Archivio del Capitolo Trentino, wyd. B. Meriggi, „Ricerche Slavistiche", 8, 1960, s. 112-125

Il più antico dizionario latino-polacco (del 1424), wyd. E. Winkler, „Ricerche Slavistiche”, 8, 1960, s. 96-111

Katalog rękopisów Biblioteki Uniwersytetu Jagiellońskiego, cz. 1, wyd. W. Wisłocki, Cracoviae 1877-1881

„Liber disparata antiqua continens”. Alexandro Masoviensi episcopo Tridentino dicatus, wyd. E. Winkler, Elementa ad fontium editiones, t. 2, Romae 1960

Stowniczek trydencki, wyd. A. Steffen, „Teki Historyczne”, 11, 1960-1961, s. 221-243

Stowniczek trydencki, wyd. A. Steffen, wyd. 2 popr., Prace Językowe, t. 1, Londyn 1963

Svatovitský rukopis, wyd. A. Patera, Praha 1886

Wokabularz trydencki, wyd. S. Urbańczyk, „Język Polski”, 42, 1962, nr 1, s. 15-29

\section{Opracowania}

Bańkowski A., Wyrazy trudne w Wokabularzu trydenckim, „Prace Filologiczne”, 36, 1991, s. 245-253

Bargieł M., Cechy dialektyczne polskich zabytków rękopiśmiennych pierwszej połowy XVI wieku, Prace Językoznawcze Komitetu Językoznawstwa PAN, t. 55, Wrocław 1969

Bąkowski L., Książę mazowiecki Aleksander, biskup trydencki, Przegl. Hist., 16, 1913, nr 1, s. 1-34

Bąkowski L., Ksiązę mazowiecki Aleksander, biskup trydencki (dokończenie), Przegl. Hist., 16, 1913, nr 2, s. 129-163

Belcarzowa E., Glosy polskie w tacińskich kazaniach średniowiecznych, cz. 3, Kraków 1997

Boulanger J.-C., Les inventeurs de dictionnaires. De l'eduba des scribes mésopotamiens au scriptorium des moines médiévaux, Ottawa 2003

Bourgain P., La fin du moyen âge. Le recul du latin, w: Le Latin médiéval, Turnhout 2005, s. 63-65

Brückner A., Neue Quellen zur Geschichte des polnischen Sprache und Literatur, „Archiv für slavische philologie", 14, 1892, s. 481-511

Brückner A., Z rękopisów petersburskich, cz. 2: Średniowieczne słownictwo polskie, „Prace Filologiczne”, 5, 1895, s. $4-48$ 
Buridant C., Lexicographie et glossographie médiévales. Esquisse de bilan et perspectives de recherche, „Lexique 4. La lexicographie au Moyen Âge”, 1986, s. 9-46

Burkhanov I., Lexicography. A Dictionary of Basic Terminology, Rzeszów 2010

Daly L.W., Daly B.A., Some Techniques in Mediaeval Latin Lexicography, „Speculum”, 39, 1964, nr 2, s. 229-239

Domański J., Leksykografia tacińska a kultura umystowa średniowiecza [rec.: La lexicographie du latin médiéval et ses rapports avec les recherches actuelles sur la civilisation du moyen age. Colloque international du Centre national de la recherche scientifique, Paris, 18-21 octobre 1978, Paris 1981], „Przegląd Tomistyczny”, 3, 1987, s 217-223

Klimecka G., Z historii tworzenia języka dokumentu polskiego wieków średnich. Formularz ciechanowski, Warszawa 1997

Koczerska M., Fikcja i rzeczywistość w formularzach polskich, w: Literatura i kultura polskiego średniowiecza, red. P. Buchwald-Pelcowa, J. Pelc, Warszawa 1995, s. 23-38

Kozłowska-Budkowa Z., Jakub z Zaborowa, w: PSB, t. 10, Wrocław 1962-1964, s. 368-369

Larczyńska A., Prawdziwe czy zmyślone? Źródła epistolarne i dokumentowe w formularzu księcia mazowieckiego Aleksandra. Próba rekonesansu badawczego, „Studia z Dziejów Średniowiecza”, 18, 2014, s. 141-154

Leńczuk M., Polskie glosy w XV-wiecznych tacińskich rękopisach jako problem historycznojęzykowy, w: Jak badać teksty staropolskie, red. T. Mika, D. Rojszczak-Robińska, O. Stramczewska, Poznań 2015, s. 79-101

Leńczuk M., Problemy terminologiczne w opisywaniu glos polskich na przyktadzie XV-wiecznych tlumaczeń kanonu mszy św., „Kwartalnik Językoznawczy”, 2010, nr 2, s. 19-37

Leńczuk M., Zapisy polskie w stownikach i glosariuszach XV w. - terminy, źródta, perspektywy badawcze, „Polonica", 35, 2015, s. 103-114

Lindsay W.M., Note on the Use of Glossaries for the Dictionary of Medieval Latin, „ALMA” („Bulletin Ducange”) 1, 1924, s. 16-19

Masłej D., Stownik a tekst. Problem znaczenia odpowiedników leksykalnych w staropolskich przektadach Psalmu 50, w: Jak badać teksty staropolskie, red. T. Mika, D. Rojszczak-Robińska, O. Stramczewska, Poznań 2015, s. $103-117$

McArthur T., Thematic Lexicography, w: The History of Lexicography, red. R.R.K. Hartmann, Amsterdam-Philadelphia 1986, s. 157-166

Michałowska T., Literatura polskiego średniowiecza, Warszawa 2011

Michałowska T., Średniowiecze, Warszawa 1995

Miethaner-Vent K., L'alphabétisation dans la lexicographie médiévale; ordre alphabétique, ses différents emplois, ses formes et son développement, „Lexique 4. La lexicographie au Moyen Âge”, 1986, s. 111-112

Mika T., Genetyczna wielowarstwowość i złożoność tekstów staropolskich a ich badania historycznojęzykowe. Rekonesans, „Biuletyn Polskiego Towarzystwa Językoznawczego”, 68, 2013, s. 131-145

Murray J.A.H., The Evolution of English Lexicography, London 1900

Piotrowski T., Zrozumieć leksykografie, Warszawa 2001

Plezia M., Dzieje leksykografii tacińskiej w Polsce, w: Stownik tacińsko-polski, Warszawa 1959, s. V-XXXIV

Rossebastiano Bart A., Alle origini della lessicografia italiana, „Lexique 4. La lexicographie au Moyen Âge”, 1986, s. 113-156

Rychterová P., The Manuscripts of Grünberg and Königinhof. Romantic Lies about the Glorious Past of the Czech Nation, w: Manufacturing a Past for the Present. Forgery and Authenticity in Medievalist Texts and Objects in Nineteenth-Century Europe, red. J.M. Bak, P.J. Geary, G. Klaniczay, Leiden-Boston 2014, s. 1-30

Schnell B., Le Vocabularius Ex quo, principal dictionnaire latin-allemand de la fin du Moyen Âge, „Lexique 4. La lexicographie au Moyen Âge", 1986, s. 81-82

Stownik literatury staropolskiej, red. T. Michałowska, Wrocław-Warszawa-Kraków 1990

Steffen A., Biga Stowniczka trydenckiego, „Język Polski”, 45, 1965, nr 4, s. 239-241

Sułkowska-Kurasiowa I., Dokumenty królewskie i ich funkcja w państwie polskim za Andegawenów i pierwszych Jagiellonów, Warszawa 1977

Thomas G., The Role of diglossia in the Development of the Slavonic Literary Languages, „Slavistična revija”, 37,1989 , nr 1, s. $273-282$

Tov E., Glosses, Interpolations, and Other Types of Scribal Additions in the Text of the Hebrew Bible, w: tenże, The Greek and Hebrew Bible, Leiden-Boston 1999, s. 53-74

Urbańczyk S., O poprawne odczytanie Wokabularza trydenckiego, „Język Polski”, 44, 1964, nr 5, s. 299-310

Urbańczyk S., Poklosie Wokabularza trydenckiego, ,Język Polski”, 42, 1962, nr 5, s. 385-386

Urbańczyk S., Stowniki, ich rodzaje i użyteczność, Wrocław 1964 
Voleková K., Česká lexikografie 15. století, Praha 2015

Weijers O., Les dictionnaires et autres répertoires, w: Méthodes et instruments du travail intellectuel au moyen âge. Etudes sur le vocabulaire intellectuel du moyen âge, red. O. Weijers, Turnhout 1990, s. 197-208

Weijers O., Dictionnaires et répertoires au moyen âge. Une étude du vocabulaire, Turnhout 1991

Weijers O., Lexicography in the Middle Ages, „Viator - Medieval and Renaissance Studies”, 20, 1989, s. 139-153

Woś J.W., Aleksander Mazowiecki - biskup trydencki (1423-1444), „Saeculum Christianum”, 6, 1999, nr 2, s. 17-31

Woś J.W., Alessandro di Masovia, vescovo di Trento (1423-1444), Trento 2001

Woś J.W., Alessandro di Masovia, vescovo di Trento e patriarca di Aquilea (1400-1444), Roma-Trento 1998

Zygner L., Piastowie mazowieccy na stolicach biskupich, w: Dziedzictwo książat mazowieckich. Stan badań i postulaty badawcze, red. J. Grabowski, R. Mroczek, P. Mrozowski, Warszawa 2017, s. 141-158

Żmigrodzki P., Wprowadzenie do leksykografii polskiej, Katowice 2009 